Nevada

Environmental

Restoration

Project

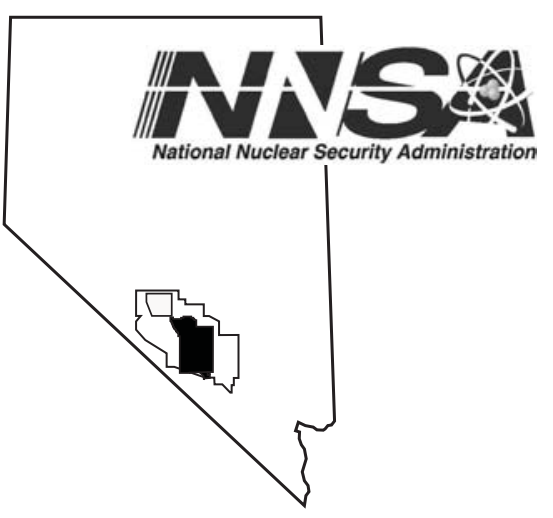

\title{
Completion Report for Well ER-2-1
}

\section{October 2004}

\section{Environmental Restoration}

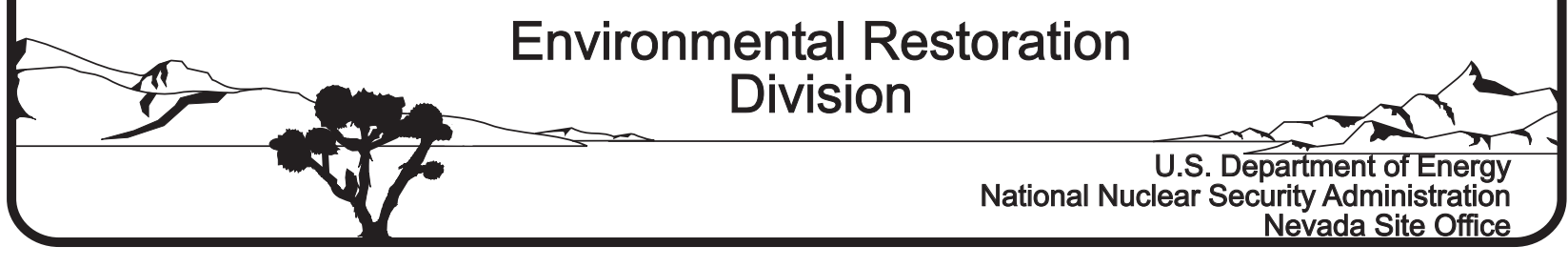




\title{
DISCLAIMER STATEMENT
}

Reference herein to any specific commercial product, process, or service by trade name, trademark, manufacturer, or otherwise, does not necessarily constitute or imply its endorsement, recommendation, or favoring by the U.S. Government or any agency thereof or its contractors or subcontractors.

\section{AVAILABILITY STATEMENT}

Available to the public, in paper, from-

\author{
U.S. Department of Commerce \\ National Technical Information Service \\ 5285 Port Royal Road \\ Springfield, VA, 22161-0002 \\ Telephone: 800.553 .6847 \\ Fax: 703.605.6900 \\ E-mail: orders@ntis.gov \\ Online ordering: http://www.ntis.gov/ordering.htm
}

Available electronically at http://www.osti.gov/bridge.

Available for a processing fee to U.S. Department of Energy and its contractors, in paper, from-

U.S. Department of Energy

Office of Scientific and Technical Information

P.O. Box 62

Oak Ridge, TN 37831-0062

Telephone: 865.576 .8401

Fax: 865.576.5728

E-mail: reports@adonis.osti.gov 


\title{
Completion Report for Well ER-2-1
}

\author{
Prepared for: \\ U.S. Department of Energy \\ National Nuclear Security Administration \\ Nevada Site Office \\ Las Vegas, Nevada
}

Prepared by:

Bechtel Nevada

Geotechnical Sciences

Las Vegas, NV

October 2004 
This page intentionally left blank. 


\section{COMPLETION REPORT FOR WELL ER-2-1}

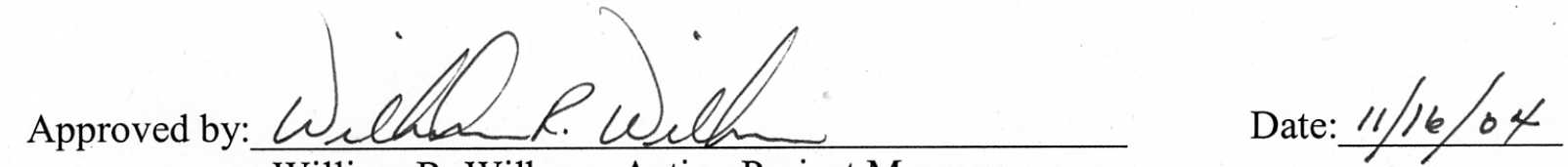

William R. Wilborn, Acting Project Manager, Underground Test Area Project

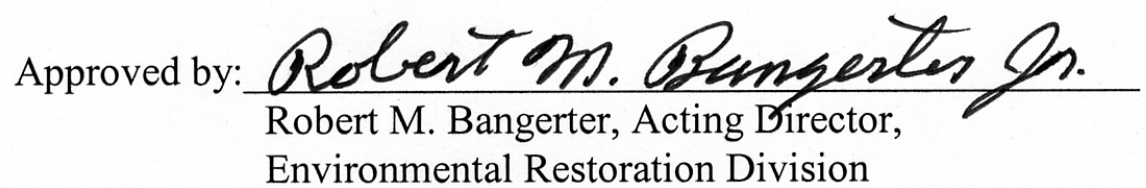
Date: $11 / 16 / 04$ 
This page intentionally left blank. 


\section{Completion Report for Well ER-2-1 \\ DOE/NV/11718--893 \\ ABSTRACT}

Well ER-2-1 was drilled for the U.S. Department of Energy, National Nuclear Security Administration Nevada Site Office (formerly Nevada Operations Office), in support of the Nevada Environmental Restoration Project at the Nevada Test Site, Nye County, Nevada. This well was drilled in February and March of 2003, as part of a hydrogeologic investigation program for the Yucca Flat/Climax Mine Corrective Action Unit in the northeastern portion of the Nevada Test Site. Well ER-2-1 was drilled as part of the Yucca Flat Corrective Action Unit Phase I drilling initiative. The well is located in northcentral Yucca Flat within Area 2 of the Nevada Test Site, and provided information regarding the radiological and physical environment near underground nuclear tests conducted in a saturated volcanic aquifer setting.

To construct the well, a 0.91-meter-diameter surface conductor hole was drilled and cased off to a depth of 35.9 meters below the surface. A 47-centimeter-diameter surface hole was drilled to the depth of 518.2 meters and cased off to the depth of 501.1 meters. The hole diameter was then decreased to 31.1 centimeters, and the borehole was advanced to a total depth of 792.5 meters. No drilling problems were encountered.

A 17.7-centimeter-inside-diameter, carbon-steel casing with internal epoxy coating was set at 633.7 meters to access the Timber Mountain lower vitric tuff aquifer. A 5.9-centimeter-inside-diameter piezometer was set at the depth of 779.9 meters to access the Yucca Flat lower confining unit. A precompletion fluid-level depth of 534.8 meters was measured in the open borehole two days after drilling was completed, which represented a rise in fluid level of approximately 138.8 meters. This may indicate the presence of the hypothesized "over-pressurized zone," a consequence of underground testing maintained by the low conductivity of zeolitic bedded tuffs. Low levels of tritium (less than 8,700 picoCuries per liter) were detected in two depth intervals during drilling. No other radionuclides were identified during drilling.

Detailed lithologic descriptions with stratigraphic assignments are included in this report. These are based on composite drill cuttings collected every 3 meters and 83 sidewall samples taken at various depths between 113.7 and 754.4 meters, supplemented by geophysical log data. Detailed petrographic, chemical, and mineralogical studies of rock samples were conducted on 27 samples of drill cuttings. The well was collared in tuffaceous alluvium, and penetrated Tertiary-age tuffs of the Timber Mountain and Paintbrush Groups, Calico Hills and Wahmonie Formations, Crater Flat Group, Grouse Canyon Formation, before reaching total depth in the Tunnel Bed Formation. 
This page intentionally left blank. 


\section{Table of Contents}

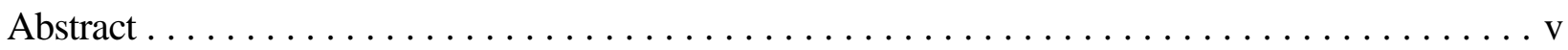

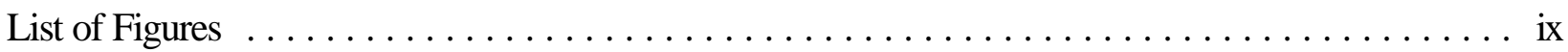

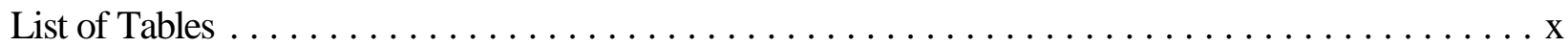

List of Acronyms and Abbreviations $\ldots \ldots \ldots \ldots \ldots \ldots \ldots \ldots \ldots \ldots \ldots \ldots \ldots \ldots \ldots$

1.0 Introduction $\ldots \ldots \ldots \ldots \ldots \ldots \ldots \ldots \ldots \ldots \ldots \ldots \ldots \ldots \ldots \ldots \ldots \ldots \ldots \ldots \ldots \ldots, 1$

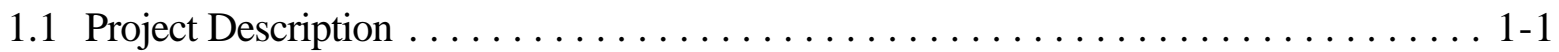

1.2 Location and Significant Nearby Features $\ldots \ldots \ldots \ldots \ldots \ldots \ldots \ldots \ldots \ldots \ldots \ldots \ldots .4$

1.2.1 Location . . . . . . . . . . . . . . . . . . . . . . . . . . . . .

1.2.2 Underground Nuclear Tests in the Vicinity of Well ER-2-1 . . . . . . . . 1-5

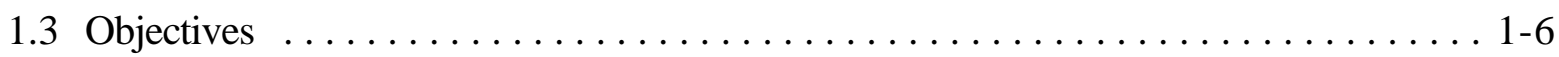

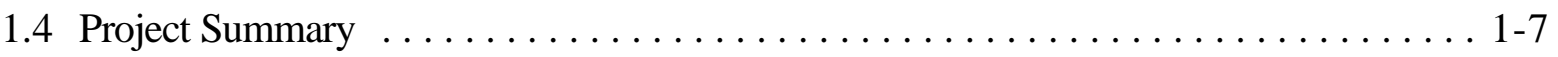

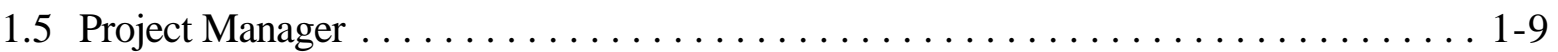

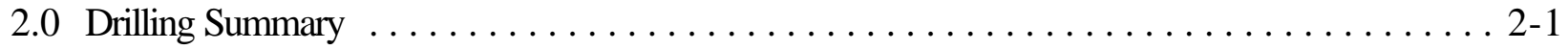

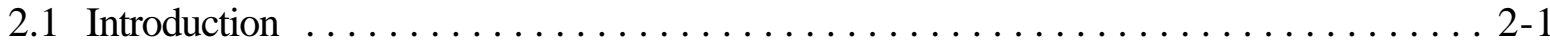

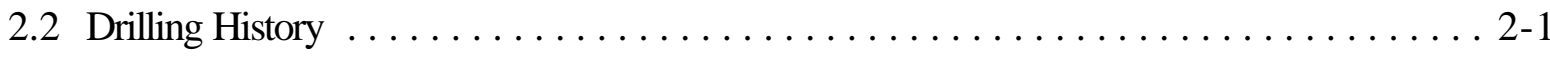

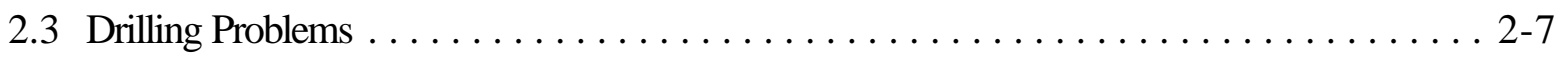

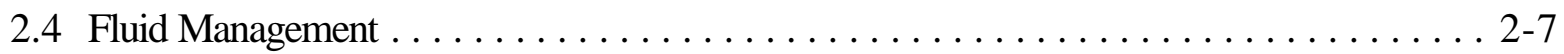

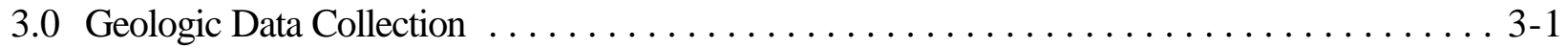

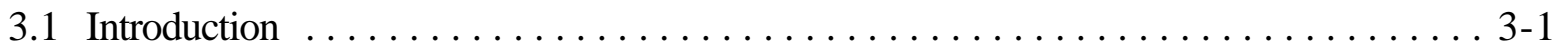

3.2 Collection of Drill Cuttings . . . . . . . . . . . . . .

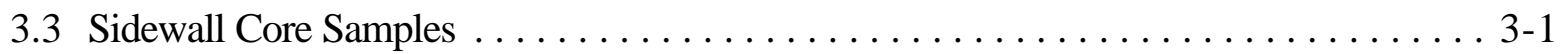

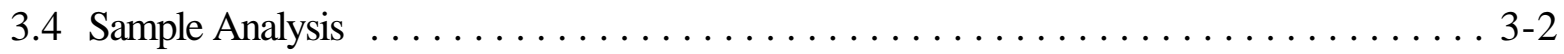

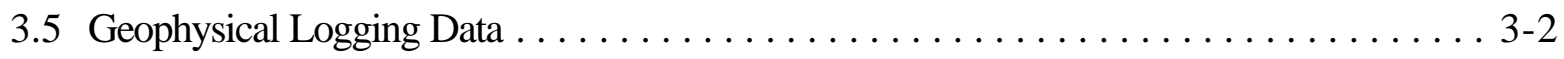

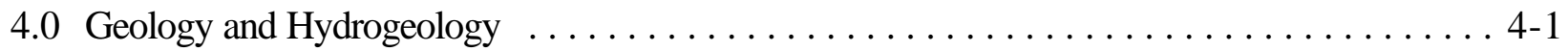

4.1 Introduction $\ldots \ldots \ldots \ldots \ldots \ldots \ldots \ldots \ldots \ldots \ldots \ldots \ldots \ldots \ldots \ldots \ldots \ldots \ldots \ldots \ldots, 1$

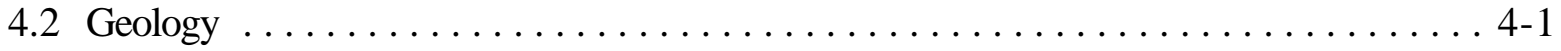

4.2 .1 Geologic Setting . . . . . . . . . . . . . . . . . . . . . . .

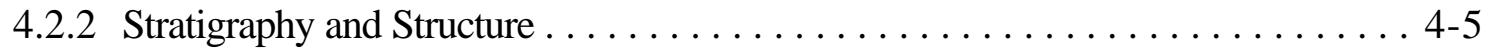

4.2 .3 Alteration $\ldots \ldots \ldots \ldots \ldots \ldots \ldots \ldots \ldots \ldots \ldots \ldots \ldots \ldots \ldots, 4-11$

4.3 Predicted versus Actual Geology $\ldots \ldots \ldots \ldots \ldots \ldots \ldots \ldots \ldots \ldots \ldots \ldots .4 .11$

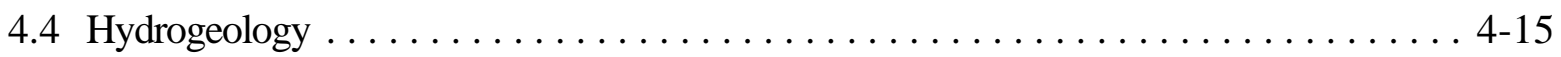




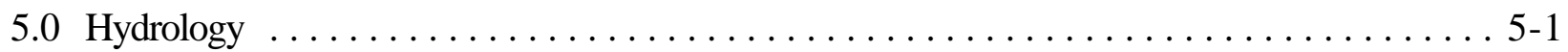

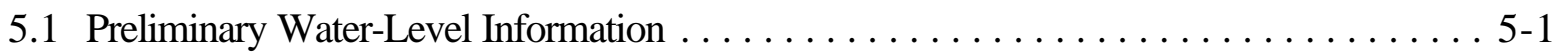

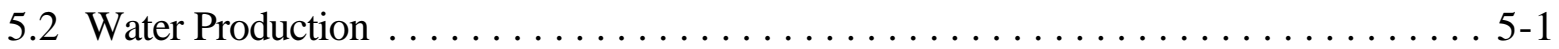

5.3 Preliminary Flow Meter Data $\ldots \ldots \ldots \ldots \ldots \ldots \ldots \ldots \ldots \ldots \ldots \ldots \ldots \ldots \ldots \ldots \ldots \ldots \ldots \ldots .2$

5.4 Preliminary Groundwater Characterization Samples $\ldots \ldots \ldots \ldots \ldots \ldots \ldots \ldots \ldots .2$

6.0 Precompletion and Open-Hole Development $\ldots \ldots \ldots \ldots \ldots \ldots \ldots \ldots \ldots \ldots \ldots$ 6-1

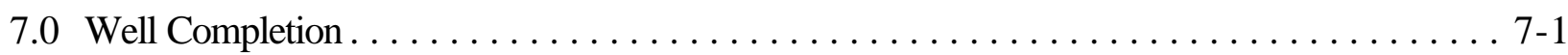

7.1 Introduction $\ldots \ldots \ldots \ldots \ldots \ldots \ldots \ldots \ldots \ldots \ldots \ldots \ldots \ldots \ldots \ldots \ldots \ldots \ldots \ldots \ldots \ldots \ldots, 1$

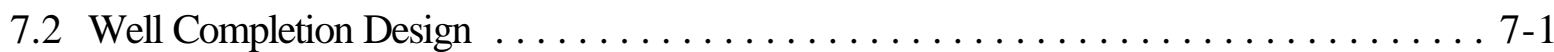

7.2.1 Proposed Completion Design $\ldots \ldots \ldots \ldots \ldots \ldots \ldots \ldots \ldots \ldots \ldots \ldots \ldots \ldots \ldots \ldots \ldots$

7.2.2 As-Built Well Completion Design $\ldots \ldots \ldots \ldots \ldots \ldots \ldots \ldots \ldots \ldots \ldots . . \ldots \ldots \ldots$

7.2.3 Rationale for Differences between Planned and Actual Well Design ......... . 7-5

7.3 Well Completion Method ................................ 7-6

8.0 Actual versus Planned Costs and Scheduling $\ldots \ldots \ldots \ldots \ldots \ldots \ldots \ldots \ldots \ldots \ldots \ldots \ldots \ldots \ldots$

9.0 Summary, Recommendations, and Lessons Learned $\ldots \ldots \ldots \ldots \ldots \ldots \ldots \ldots$ 9-1

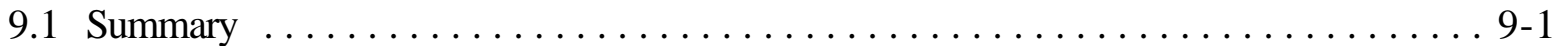

9.2 Recommendations $\ldots \ldots \ldots \ldots \ldots \ldots \ldots \ldots \ldots \ldots \ldots \ldots \ldots \ldots \ldots, \ldots \ldots \ldots, 2$

9.3 Lessons Learned ...................................... 9-2

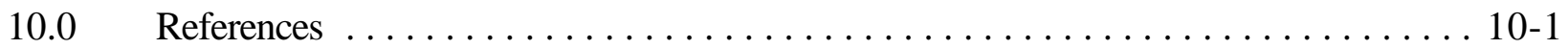

Appendix A - Drilling Data

A-1 Drilling Parameter Logs for Well ER-2-1

A-2 Casing Data for Well ER-2-1

A-3 Well ER-2-1 Drilling Fluids and Cement Composition

Appendix B - Well ER-2-1 Fluid Management Data

Well ER-2-1 Fluid Disposition Reporting Form

Appendix C - Detailed Lithologic Log for Well ER-2-1

Appendix D - Geophysical Logs Run in Well ER-2-1

Distribution List 


\section{List of Figures}

Number

Title

Page

1-1 Reference Map Showing Location of Well ER-2-1 . . . . . . . . . . . . . . . 1-2

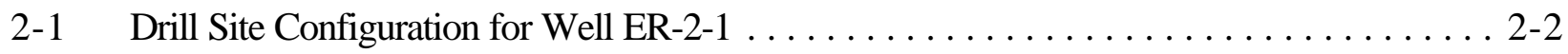

2-2 Well ER-2-1 Drilling and Completion History $\ldots \ldots \ldots \ldots \ldots \ldots \ldots \ldots \ldots \ldots$

4-1 Generalized Surface Geologic Map of the Nevada Test Site Area Showing

Location of Well ER-2-1 . . . . . . . . . . . . . . . . . . . . . . . . 4-3

4-2 Surface Geologic Map of the Well ER-2-1 Site $\ldots \ldots \ldots \ldots \ldots \ldots \ldots \ldots \ldots$. . . . . . . .

4-3 West-East Geologic Cross Section A-A' through Well ER-2-1 . . . . . . . . . . . . . . 4-9

4-4 North-South Geologic Cross Section B-B' through Well ER-2-1 . . . . . . . . . . . . 4-10

4-5 Geology and Hydrogeology of Well ER-2-1 . . . . . . . . . . . . . . . . 4-13

4-6 Predicted and Actual Stratigraphy at Well ER-2-1 . . . . . . . . . . . . . . 4-16

4-7 West-East Hydrogeologic Cross Section C-C' through Well ER-2-1 . . . . . . . . . 4-17

7-1 As-Built Completion Schematic for Well ER-2-1 . . . . . . . . . . . . . . . . 7-2

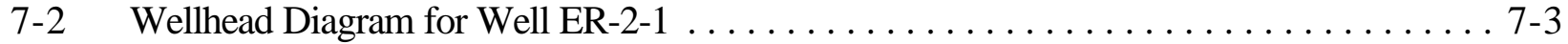

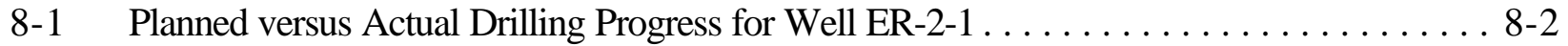

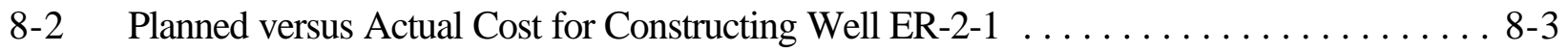




\section{List of Tables}

Number

Title

Page

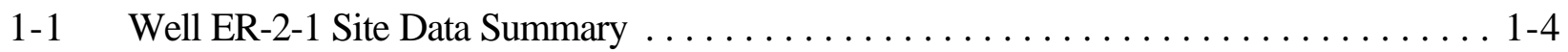

1-2 Selected Information for Underground Nuclear Tests Relevant to Well ER-2-1 . . . . . . 1-5

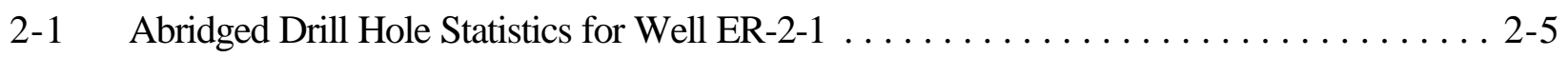

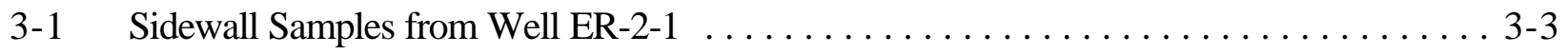

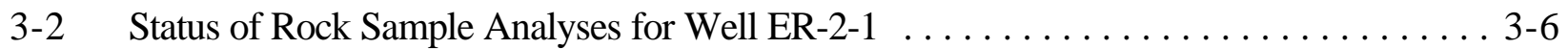

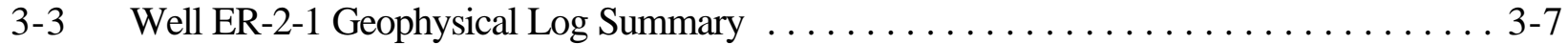

7-1 Construction Summary for Well ER-2-1 Completion Strings $\ldots \ldots \ldots \ldots \ldots \ldots \ldots . . .7-4$

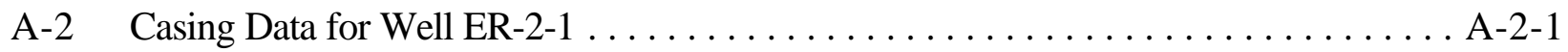

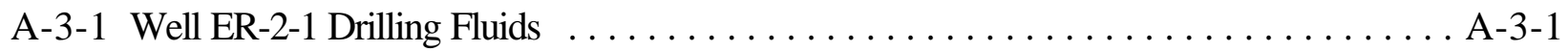

A-3-2 Well ER-2-1 Cement Composition ........................ A-3-1

D-1 Well ER-2-1 Geophysical Logs Presented $\ldots \ldots \ldots \ldots \ldots \ldots \ldots \ldots \ldots \ldots \ldots \ldots \ldots \ldots \ldots \ldots$ 


\section{List of Acronyms and Abbreviations}

\begin{tabular}{|c|c|}
\hline $\mathrm{BN}$ & Bechtel Nevada \\
\hline $\mathrm{C}$ & Celsius \\
\hline CAIP & Corrective action investigation plan \\
\hline CAU & Corrective action unit \\
\hline $\mathrm{cm}$ & centimeter(s) \\
\hline DOE & U.S. Department of Energy \\
\hline DOE/NV & U.S. Department of Energy, Nevada Operations Office \\
\hline DRI & Desert Research Institute \\
\hline $\mathrm{E}$ & east \\
\hline $\mathrm{EC}$ & Electrical Conductivity \\
\hline $\mathrm{F}$ & Fahrenheit \\
\hline FAWP & Field activity work package \\
\hline FFACO & Federal Facility Agreement and Consent Order \\
\hline FMP & Fluid Management Plan \\
\hline FY & Fiscal Year \\
\hline $\mathrm{ft}$ & foot (feet) \\
\hline gpm & gallons per minute \\
\hline HES & Halliburton Energy Services \\
\hline $\mathrm{HGU}$ & Hydrogeologic unit \\
\hline HSU & Hydrostratigraphic unit \\
\hline in. & inch(es) \\
\hline IT & IT Corporation \\
\hline LCA & Lower carbonate aquifer \\
\hline LLNL & Lawrence Livermore National Laboratory \\
\hline lpm & liters per minute \\
\hline LANL & Los Alamos National Laboratory \\
\hline $\mathrm{LiBr}$ & lithium bromide \\
\hline $\mathrm{m}$ & meter(s) \\
\hline $\mathrm{N}$ & north \\
\hline NAD & North American Datum \\
\hline NNSA/NV & National Nuclear Security Administration Nevada Operations Office \\
\hline NNSA/NSO & National Nuclear Security Administration Nevada Site Office \\
\hline NTS & Nevada Test Site \\
\hline $\mathrm{pCi} / \mathrm{L}$ & PicoCurie(s) per liter \\
\hline Shaw & Shaw Environmental, Inc. \\
\hline TCU & tuff confining unit \\
\hline
\end{tabular}


TD

TFM

TM-UVTA

TM-WTA

TM-LVTA

TWG

UGTA

UDI

USGS

YF-LCU total depth

Thermal flow meter

Timber Mountain upper vitric-tuff aquifer

Timber Mountain welded-tuff aquifer

Timber Mountain lower vitric-tuff aquifer

Technical Working Group

Underground Test Area

United Drilling, Inc.

United States Geological Survey

Yucca Flat lower confining unit 


\subsection{Introduction}

\subsection{Project Description}

Well ER-2-1 was drilled for the U.S. Department of Energy (DOE), National Nuclear Security Administration Nevada Site Office (NNSA/NSO; formerly Nevada Operations Office [DOE/NV]) in support of the Nevada Environmental Restoration Project at the Nevada Test Site (NTS), Nye County, Nevada. Well ER-2-1 was the last in a series of five wells drilled as part of a hydrogeologic investigation program for the Yucca Flat/Climax Mine Corrective Action Unit (CAU) Number 97. Data from these wells will allow for more accurate modeling of groundwater flow and radionuclide migration in the region. Some of the wells may also function as long-term monitoring wells.

The Yucca Flat hydrogeologic investigation well drilling program is part of the NNSA/NSO Environmental Restoration Division's Underground Test Area (UGTA) project at the NTS. The goals of the UGTA project include evaluating the nature and extent of contamination in groundwater due to underground nuclear testing, and establishing a long-term groundwater monitoring network. As part of the UGTA project, scientists are developing computer models to predict groundwater flow and contaminant migration within and near the NTS. To build and test these models, it is necessary to collect geologic, geophysical, and hydrologic data from new and existing wells to define groundwater migration pathways, migration rates, and quality.

The Yucca Flat hydrogeologic investigation well program is also part of the Corrective Action Investigation Plan (CAIP; DOE/NV, 2000a) for the Yucca Flat/Climax Mine CAU. The CAIP is a requirement of the Federal Facility Agreement and Consent Order (FFACO, 1996), agreed to by the DOE, the Nevada Division of Environmental Protection, and the U.S. Department of Defense.

Well ER-2-1 was drilled as part of the Yucca Flat CAU Phase I drilling initiative. The well is located in north-central Yucca Flat, within Area 2 of the NTS (Figure 1-1), and provided information regarding the radiological and physical environment near underground nuclear tests conducted in a saturated volcanic aquifer setting. 


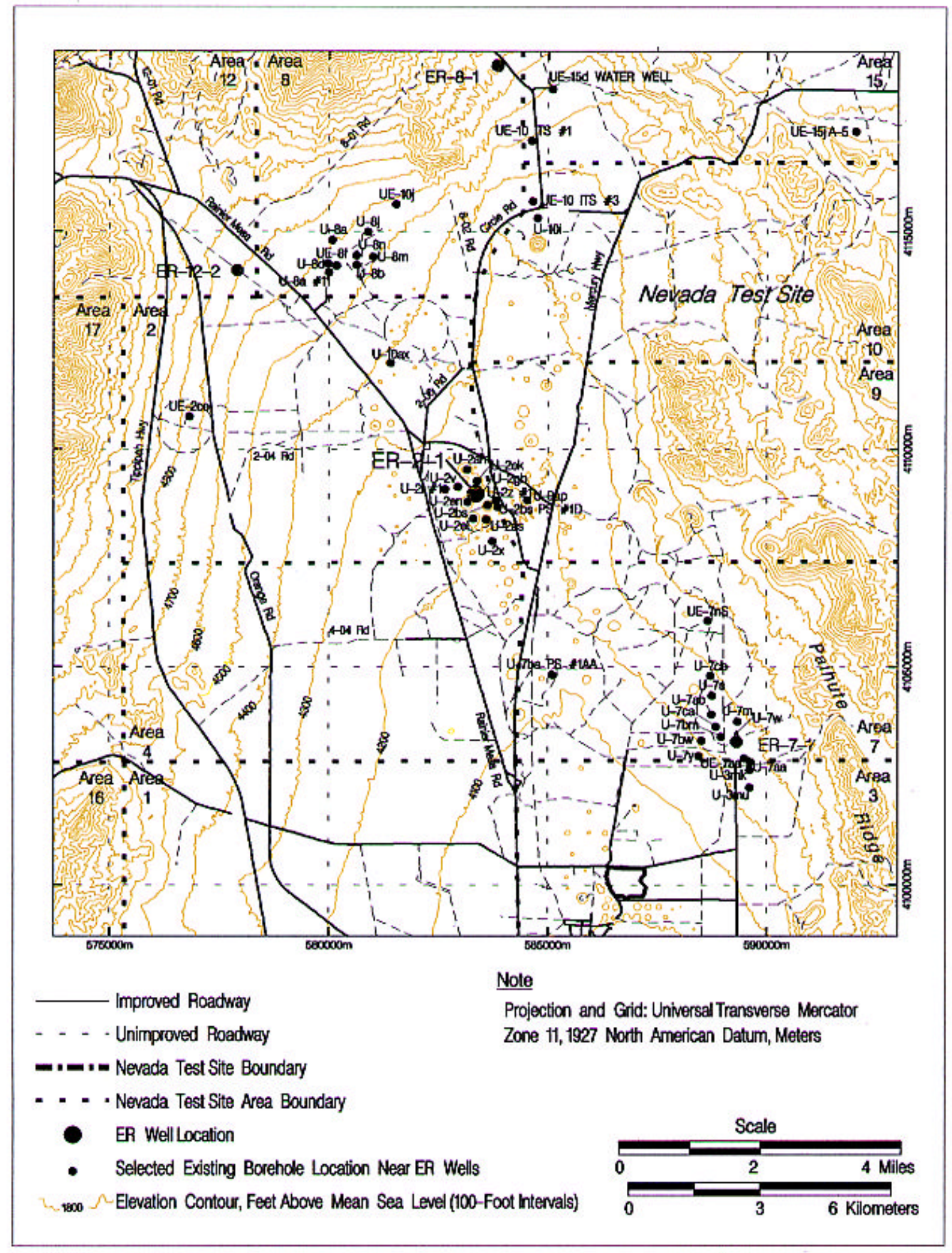

Figure 1-1

Reference Map Showing Location of Well ER-2-1 
Shaw Environmental, Inc. (Shaw) was the principal environmental contractor for the project, and Shaw personnel collected geologic and hydrologic data during drilling. The drilling company was United Drilling, Incorporated (UDI), a subcontractor to Bechtel Nevada (BN). Site supervision, engineering, construction, inspection, and geologic support were provided by BN. The roles and responsibilities of these and other contractors involved in the project are described in Contract Number DE-RP-0895NV11808, and in BN Field Activity Work Plan (FAWP) number D-002-001.03 (BN, 2003). The UGTA Technical Working Group (TWG), a committee of scientists and engineers comprising NNSA/NSO, Lawrence Livermore National Laboratory, Los Alamos National Laboratory (LANL), and contractor personnel, provided additional technical advice during drilling, design, and construction of the well. See Yucca Flat Hydrogeologic Investigation Wells Drilling and Completion Criteria (IT, 2002) for descriptions of the general plan and goals of the Yucca Flat drilling initiative project, as well as specific goals for each planned well.

General guidelines for managing fluids used and generated during drilling, completion, and testing of UGTA wells are provided in the UGTA Fluid Management Plan (FMP), Revision 3 (DOE/NV, 2002a), an attachment to the UGTA Waste Management Plan (DOE/NV, 2002b). Estimates of production of fluid and drill cuttings for the Yucca Flat holes are given in Appendix F of the drilling and completion criteria document for the Yucca Flat drilling project (IT, 2002), along with sampling requirements and contingency plans for management of any hazardous waste produced. Additional details are included in the well-specific Fluid Management Strategy (Wycoff, 2003). All activities were conducted according to BN FAWP number 002-001.03 (BN, 2003) and the UGTA Project Health and Safety Plan (BN, 2001a).

This report presents construction data and summarizes scientific data gathered during drilling of Well ER-2-1. Some of the information in this report is preliminary and unprocessed but is being released with the drilling and completion data for convenient reference. A well data report prepared by Shaw (Shaw, 2003) contains additional information on fluid management, waste management, and environmental compliance. Updated geologic information (including any changes in the geologic interpretation) will be compiled in the documentation package for the Yucca Flat hydrostratigraphic framework model to be prepared by BN. Information on well development, aquifer testing, and groundwater analytical sampling will be compiled and disseminated separately. 


\subsection{Location and Significant Nearby Features}

Well ER-2-1 is located in north-central Yucca Flat in the eastern portion of NTS Area 2 (Figure 1-1). This part of Yucca Flat, west of the Yucca fault, was the site of many underground tests. The drill site is 100 meters (m) (330 feet [ft]) west of surface ground zero of the closest test and is centrally located between three larger tests (see Section 1.2.2).

\subsubsection{Location}

The Nevada State (central zone) plane coordinates (North American Datum [NAD] 1983) are North (N) 6,263,694.3 $\mathrm{m}$ and East (E) 553,660.8 $\mathrm{m}$ at the wellhead. The ground surface in the immediate area has been leveled and spread with gravel from previous activities. The elevation of the construction pad is $1,285.1 \mathrm{~m}(4,216.2 \mathrm{ft})$ above mean sea level. Surface drainage in the vicinity of the Well ER-21 location is to the southeast toward the center of the valley, and southward along the Yucca fault.

Additional information about Well ER 2-1 is provided in Table 1-1.

Table 1-1

Well ER-2-1 Site Data Summary

\begin{tabular}{|c|c|}
\hline Well Designation & ER-2-1 \\
\hline Site Coordinates ${ }^{a}$ & $\begin{array}{l}\text { Nevada State Plane (central zone) (NAD 83): } \\
\text { N 6,263,694.3 m (N 20,550,137.0 ft) } \\
\text { E 553,660.8 m (E 1,816,465.6 ft) } \\
\text { Nevada State Plane (central zone) (NAD 27): } \\
\text { N 865,134.9 ft } \\
\text { E 676,309.8 ft } \\
\text { Universal Transverse Mercator (Zone 11) (NAD 83): } \\
\text { N 4,108,977.9 m } \\
\text { E 583,334.6 m }\end{array}$ \\
\hline Surface Elevation $^{\mathrm{a}, \mathrm{b}}$ & $1,285.1 \mathrm{~m}(4,216.2 \mathrm{ft})$ \\
\hline Total Drilled Depth (TD) & $792.5 \mathrm{~m}(2,600 \mathrm{ft})$ \\
\hline Date Reached TD & March 2, 2002 \\
\hline Fluid-Level Depth ${ }^{c}$ & $534.8 \mathrm{~m}(1,754.6 \mathrm{ft})$ \\
\hline Fluid-Level Elevation & $750.3 \mathrm{~m}(2,461.6 \mathrm{ft})$ \\
\hline
\end{tabular}

a Measurement made by BN Survey.

b Elevation at top of construction pad. National Geodetic Vertical Datum, 1929.

c Preliminary composite, open-hole fluid level measured on March 4, 2003. Fluid levels in the borehole rose

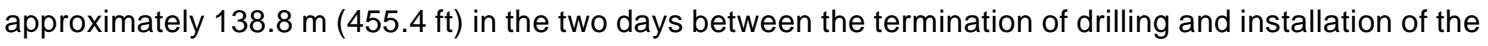
completion strings (Shaw, 2003). The level reported here is the last measurement made before installation of the completion strings. 


\subsubsection{Underground Nuclear Tests in the Vicinity of Well ER-2-1}

More than two dozen underground nuclear tests (mostly of yields in the 20- to 200-kiloton range) were conducted near the Well ER-2-1 site. The four closest tests were PANAMINT (U-2gb), CHIBERTA (U-2ek), REBLOCHON (U-2en), and STARWORT (U-2bs). The site of Well ER-2-1 is approximately $100.0 \mathrm{~m}$ (328 ft) west of the PANAMINT surface ground zero. CHIBERTA (U-2ek) is $265.2 \mathrm{~m}$ (870 ft) north of Well ER-2-1, and REBLOCHON (U-2en) is $256.0 \mathrm{~m}(840 \mathrm{ft}$ ) southwest of Well ER-2-1.

STARWORT was conducted in 1973, CHIBERTA in 1975, and REBLOCHON in 1975 (DOE/NV, 2000b). PANAMINT, the most recent test in the area, was conducted in 1986. PANAMINT was conducted above the water table, and the other tests were conducted below the water table. Additional information pertaining to these and other nearby tests is provided in Table 1-2.

Table 1-2

Selected Information for Underground Nuclear Tests Relevant to Well ER-2-1

\begin{tabular}{|c|c|c|c|c|c|c|c|c|}
\hline $\begin{array}{c}\text { Emplaceme } \\
\text { nt Hole } \\
\text { Name }\end{array}$ & Test Name ${ }^{a}$ & Test Date ${ }^{a}$ & $\begin{array}{l}\text { Depth of } \\
\text { Burial } \\
\text { (meters) }\end{array}$ & $\begin{array}{c}\text { Static } \\
\text { Water } \\
\text { Level } \\
\text { Depth } \\
\text { (meters) }\end{array}$ & $\begin{array}{c}\text { Yield }^{\text {a }} \\
\text { (kilotons) }\end{array}$ & $\begin{array}{l}\text { Cavity } \\
\text { Radius } \\
\text { (meters) }\end{array}$ & $\begin{array}{l}\text { Working } \\
\quad \text { Point } \\
\text { Formation }\end{array}$ & $\begin{array}{l}\text { Working } \\
\text { Point HSU d }\end{array}$ \\
\hline U2am & COMMODORE & 05/20/1967 & 747 & 548.9 & 250 & 69 & Tn4 & YF-LCU \\
\hline U2bs & STARWORT & 04/26/1973 & 564 & 525.3 & 90 & 53 & pre-Tmr & TM-LVTA \\
\hline U2ek & CHIBERTA & $12 / 20 / 1975$ & 716 & 540.1 & $20-200$ & 65 & Tn4 & YF-LCU \\
\hline U2el & MARSILLY & 04/05/1977 & 690 & 519.9 & $20-150$ & 60 & Tc & YF-LCU \\
\hline U2en & REBLOCHON & 02/23/1978 & 658 & 534.2 & $20-150$ & 60 & pre-Tmr & TM-LVTA \\
\hline U2v & AGILE & 02/23/1967 & 732 & 543.6 & $20-200$ & 65 & Tmrh & TM-LVTA \\
\hline U2gb & PANAMINT & 05/21/1986 & 480 & 528.4 & $<20$ & 33 & Tmr & TM-LVTA \\
\hline U2as & CLARKSMOBILE & 05/17/1968 & 473 & 515.2 & $20-200$ & 72 & Tmr & TM-LVTA \\
\hline
\end{tabular}

a Source: DOE/NV, 2000b.

b Estimated using announced highest yield and published equation.

c $\quad$ Tn4 = Tunnel Formation, bed 4; pre-Tmr = pre Rainier Mesa Tuff, post-Wahmonie Formation; Tc = Crater Flat Group; Tmrh = tuff of Holmes Road; Tmr = Rainier Mesa Tuff

d YF-LCU = Yucca Flat-lower confining unit; TM-LVTA = Timber Mountain- lower vitric tuff aquifer. 
A variety of test-related surface effects has been mapped in the vicinity, including collapse craters and associated radial and circumferential surface fractures, northeast-trending linear fractures, pressure ridges, and the surface trace of the Yucca fault. Composite post-shot surface effects in the vicinity of Well ER-2-1 are included in Figure A.4-1 of IT, 2002.

\subsection{Objectives}

Well ER-2-1 is an intermediate-depth (792.5 m [2,600 ft]), near-field, hydrogeologic investigation well. The primary purpose of constructing Well ER-2-1 is to characterize the radiological and physical environment near underground nuclear tests conducted in a saturated volcanic aquifer setting, where the local groundwater flow direction is uncertain. Information from the completion, sampling, and later hydraulic testing at Well ER-2-1 will help establish the physical characteristics, hydrologic source-term, and hydraulic parameters for the near-field environment, and provide a means of investigating possible contaminant migration in saturated volcanic aquifers. These data will be applied to future flow and transport modeling for the Yucca Flat/Climax Mine CAU.

This well is located in the center of a cluster of tests, most of which were conducted in the saturated volcanic aquifers (e.g. the Timber Mountain lower vitric-tuff aquifer [TM-LVTA]). However, a few nearby tests were conducted in other media, including the zeolitic tuffs (Yucca Flat lower confining unit [YF-LCU], in the deeper Emplacement Hole, U-2ek) and unsaturated volcanic aquifer-like rocks (the shallower Emplacement Hole, U-2gb). The location of this near-field well within a cluster of test locations was selected so that the chance of encountering radionuclides from a test cavity would be maximized despite any variations in local groundwater flow directions.

Well-specific objectives, as discussed in Appendix A of the drilling criteria document (IT, 2002), include the following:

- Obtain geologic samples and geophysical data that will aid in defining hydrostratigraphic units (HSUs), characterize any geologic structures, and determine bulk hydraulic properties of the HSUs encountered.

- Obtain geologic samples for detailed mineralogical analyses. These analyses will define the vertical distribution of reactive minerals such as clays, zeolites, and iron oxides.

- Obtain near-field physical properties, including detailed fracture data for overall characterization of the Timber Mountain volcanic aquifers and the underlying zeolitized tuffs. 
- Obtain representative aqueous geochemistry samples:

» at the water table

$\gg$ from the volcanic aquifers

» from the underlying zeolitic tuffs

Additional data that will help refine knowledge of the hydrology in the near-field environment will be obtained during later hydraulic testing at this well. Specific criteria for these later tests will be defined elsewhere, but ultimately, Well ER-2-1 is expected to provide the following:

- Data for determination of the vertical hydraulic gradient.

- Data for determination of vertical and horizontal conductivity.

- Hydraulic properties of the HSUs penetrated.

- Information concerning the potential for local groundwater flow toward and/or along a significant fault (the Yucca fault).

Well ER-2-1 is located approximately $716.3 \mathrm{~m}(2,350 \mathrm{ft})$ west of the surface trace of the Yucca fault, a structure that might influence local flow of groundwater laterally (toward the fault) and vertically (between aquifers). The borehole was not expected to cross the Yucca fault, but studies planned for this site will address potential hydrologic shortcuts from shallower volcanic aquifers to the underlying lower carbonate aquifer (LCA) via other documented or inferred faults.

\subsection{Project Summary}

This section summarizes Well ER-2-1 construction operations; the details are provided in Sections 2.0 through 8.0 of this report.

The surface conductor hole was constructed by augering a 91.4-centimeter $(\mathrm{cm})$ (36-inch [in.]) diameter hole to a depth of $36.3 \mathrm{~m}$ (119 ft) and installing a string of 20-in. conductor casing to $35.9 \mathrm{~m}$ (117.7 ft). Drilling of the main hole with an 181/2-in. rotary bit, using an air-water-foam fluid (with a polymer additive as required) in conventional circulation, began on February 22, 2003. The planned depth to set the surface casing, $518.2 \mathrm{~m}(1,700 \mathrm{ft})$, was reached on February 24, 2003. At this point, drilling was suspended for geophysical logging, and then the $13 \mathrm{~d}$-in. surface casing string was landed at $501.1 \mathrm{~m}$ (1,643.9 ft) on February 27, 2003. Drilling continued with a 121/4-in. bit to the planned 
total depth (TD) of $792.5 \mathrm{~m}$ (2,600 ft), reached on March 2, 2004. Geophysical logging was conducted before the completion string was installed.

Water production was first noted while drilling at the depth of approximately $554.1 \mathrm{~m}(1,818 \mathrm{ft})$, and ranged from about 7.6 to 56.8 liters per minute (lpm) (2 to 15 gallons per minute [gpm]). During geophysical logging operations on March 4, 2003, two days after the termination of drilling, the composite, open-hole fluid level was measured at a depth of $534.8 \mathrm{~m}(1,754.6 \mathrm{ft})$. This was approximately $138.8 \mathrm{~m}$ (455.5 ft) higher than measured during immediately after TD was reached.

Tritium levels above background were measured in two intervals while drilling Well ER-2-1. The upper interval, at 328.0 to $490.7 \mathrm{~m}$ (1,076 to 1,610 ft), was within the vadose zone, and the lower interval, 743.7 to $765.0 \mathrm{~m}$ (2,440 to $2,510 \mathrm{ft})$, was within the saturated zone. Tritium levels less than 8,700 picoCuries per liter $(\mathrm{pCi} / \mathrm{L}$ ) were measured in both intervals, and background levels were measured in between. However, no other radionuclides above background levels were noted during drilling of Well ER-2-1.

Composite drill cuttings were collected every $3.0 \mathrm{~m}(10 \mathrm{ft})$ from $36.6 \mathrm{~m}(120 \mathrm{ft})$ to TD, and 83 sidewall core samples were taken at various depths between 113.7 and $754.4 \mathrm{~m}$ (373 and 2,475 ft). Openhole geophysical logging of the well was conducted to help verify the geology and characterize the hydrology of the rocks; some logs also aided in the construction of the well by indicating borehole volume and condition. The well penetrated $425.2 \mathrm{~m}$ (1,395 ft) of tuffaceous alluvium, $152.4 \mathrm{~m}$ (500 ft) of unaltered ash-flow tuffs of the Ammonia Tanks and Rainier Mesa Tuffs, $6.1 \mathrm{~m}$ (20 ft) of vitric bedded tuffs related to the Tuff of Holmes Road, and $208.8 \mathrm{~m}$ (685 ft) of zeolitic bedded tuffs related to (from youngest to oldest) the pre-Timber Mountain, Paintbrush Groups, Calico Hills and Wahmonie Formations, Crater Flat Group, Grouse Canyon and Tunnel Formation, in which Well ER-2-1 reached TD.

The well was completed slightly different than planned because of low water production within the target unit, the YF-LCU. A string of $2 \mathrm{f}$-in. tubing was set at $779.9 \mathrm{~m}(2,558.6 \mathrm{ft})$ to serve as a piezometer. This tubing is slotted in the interval 760.6 to $779.9 \mathrm{~m}(2,495.4$ to $2,558.6 \mathrm{ft})$ to provide access to the YF-LCU, which was gravel-packed and isolated with cement. A string of 7e -in. carbon-steel casing was set at the depth of $633.7 \mathrm{~m}(2,079.2 \mathrm{ft})$. This production casing is slotted in the interval 500.4 to $633.7 \mathrm{~m}(1,641.8$ to $2,079.2 \mathrm{ft})$ to provide access to the TM-LVTA and the uppermost portion of the YF-LCU. 


\subsection{Project Manager}

Inquiries concerning Well ER-2-1 should be directed to the UGTA Project Manager at:

U.S. Department of Energy

National Nuclear Security Administration

Nevada Site Office

Environmental Restoration Division

Post Office Box 98518

Las Vegas, Nevada 89193-8518 
This page is intentionally left blank. 


\subsection{Drilling Summary}

\subsection{Introduction}

This section contains detailed descriptions of the drilling process and fluid management issues.

The general drilling requirements for all Fiscal Year (FY) 2003 Yucca Flat wells were provided in Yucca Flat Hydrogeologic Investigation Wells Drilling and Completion Criteria (IT, 2002). Specific requirements for Well ER-2-1 were outlined in FAWP number D-002-001.03 (BN, 2003). Figure 2-1 shows the layout of the drill site. Figure 2-2 is a chart of the drilling and completion history for Well ER-2-1. A summary of drilling statistics for the well is given in Table 2-1. The following information was compiled primarily from $\mathrm{BN}$ daily drilling reports.

\subsection{Drilling History}

Field operations at Well ER-2-1 began on January 22, 2003, when a BN drill crew used an auger rig to drill a 91.4-cm (36-in.) diameter conductor hole to the depth of $36.3 \mathrm{~m}$ (119 ft). A string of 20-in. conductor casing was set at the depth of $35.9 \mathrm{~m}$ ( $117.7 \mathrm{ft}$ ). The bottom joint of this casing is belled to facilitate re-entry of drilling tools. The first stage of cement was placed through the center of the casing and filled the inside and annulus of the casing to $32.3 \mathrm{~m}$ (106 ft). The annulus was then fully cemented to ground level on February 3, 2003.

The UDI crews rigged up the Wilson Mogul 42B Double Drum Rig Number 5, from February 12 to 21,2003 . Drilling of the main hole with an 181/2-in. rotary bit using air, water, and foam ("air-foam") in conventional circulation began on February 22, 2003. The amounts of polymer and foaming agent in the drilling fluid, and the fluid injection rate, were adjusted as necessary during drilling to maintain superior circulation and penetration rate, and to minimize borehole sloughing.

The borehole was advanced to the planned casing point of $518.2 \mathrm{~m}(1,700 \mathrm{ft})$ with no problems. Low levels of tritium (less than $8,700 \mathrm{pCi} / \mathrm{L}$ ) were detected in the drilling fluid returns through the depth interval 328.0 to $490.7 \mathrm{~m}$ (1,076 to 1,610 ft). Because low levels of tritium had already been detected in the vadose zone, it was decided to set surface casing above the predicted water level. Following this strategy would simplify logging and casing operations should high levels of contamination be present at the water table. Negligible amounts of fill (due to sloughing of the borehole wall) had been encountered when drilling was stopped to add drill pipe (make a connection). The drillers circulated the air-foam system to clean and condition the hole, pulled 


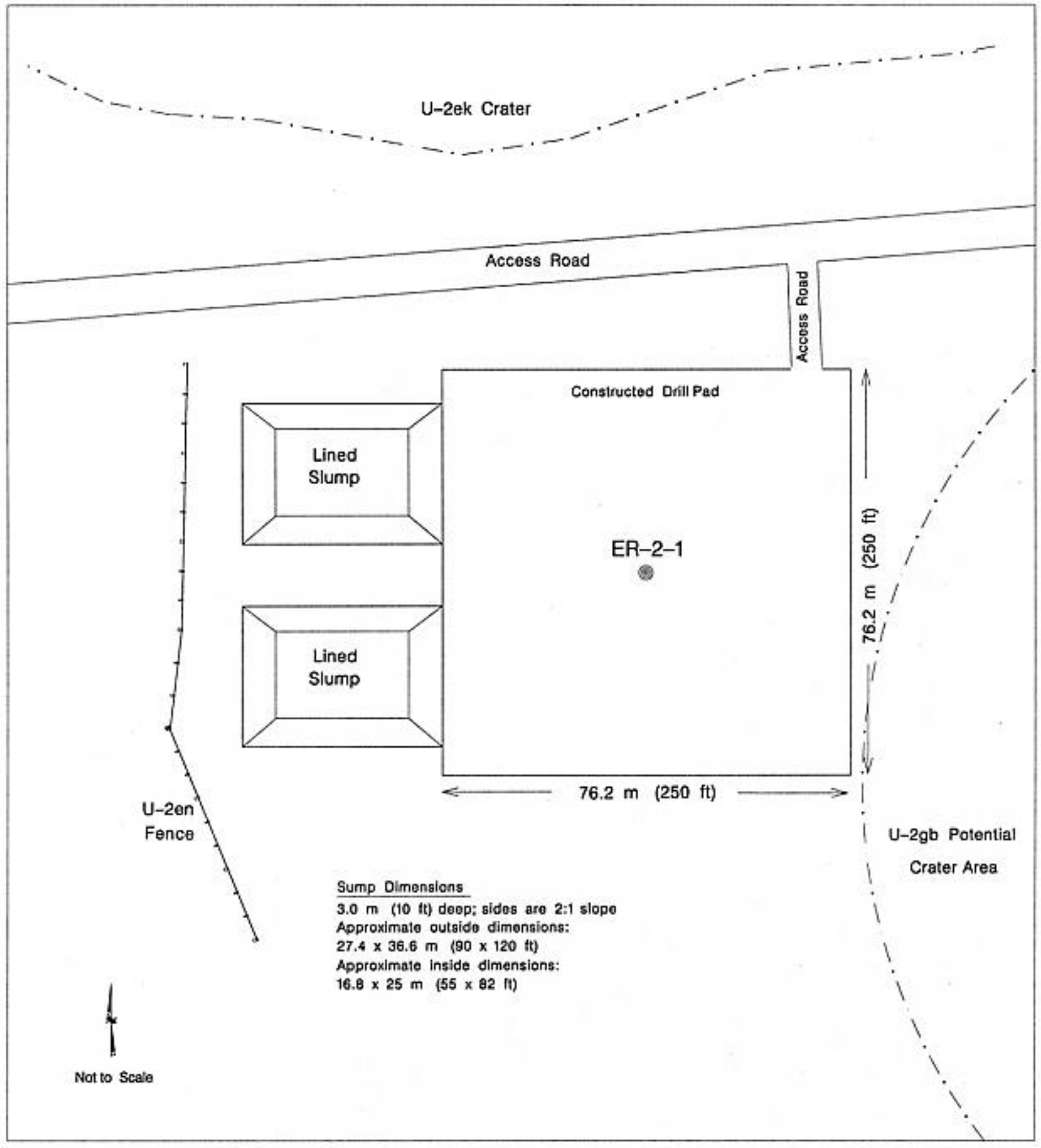

Figure 2-1

Drill Site Configuration for Well ER-2-1 


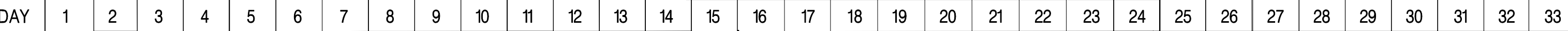
WELL ER-2-1 SUMMARY

Activity

Begin drilling conductor hole: $\quad 01 / 22 / 2003$

20-in. casing set to $35.9 \mathrm{~m}$ (117.65 ft): $\quad 01 / 28 / 2003$

egin driling 18 th in. surface hole:

$7925 \mathrm{~m}(2.600$ (t)

$03 / 02 / 2003$

BHA Bottom hole assembly

$\mathrm{cm}$ centimeter(s)

DRI Desert Research Institute

foot (feet)

inch(es)

$m$ meter(s)

TD Total depth

TIH Trip into hole

TOH Trip out of hole

UDI United Drillers, Inc

wOC Wait on cement

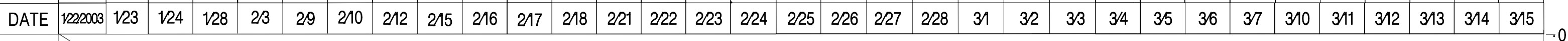
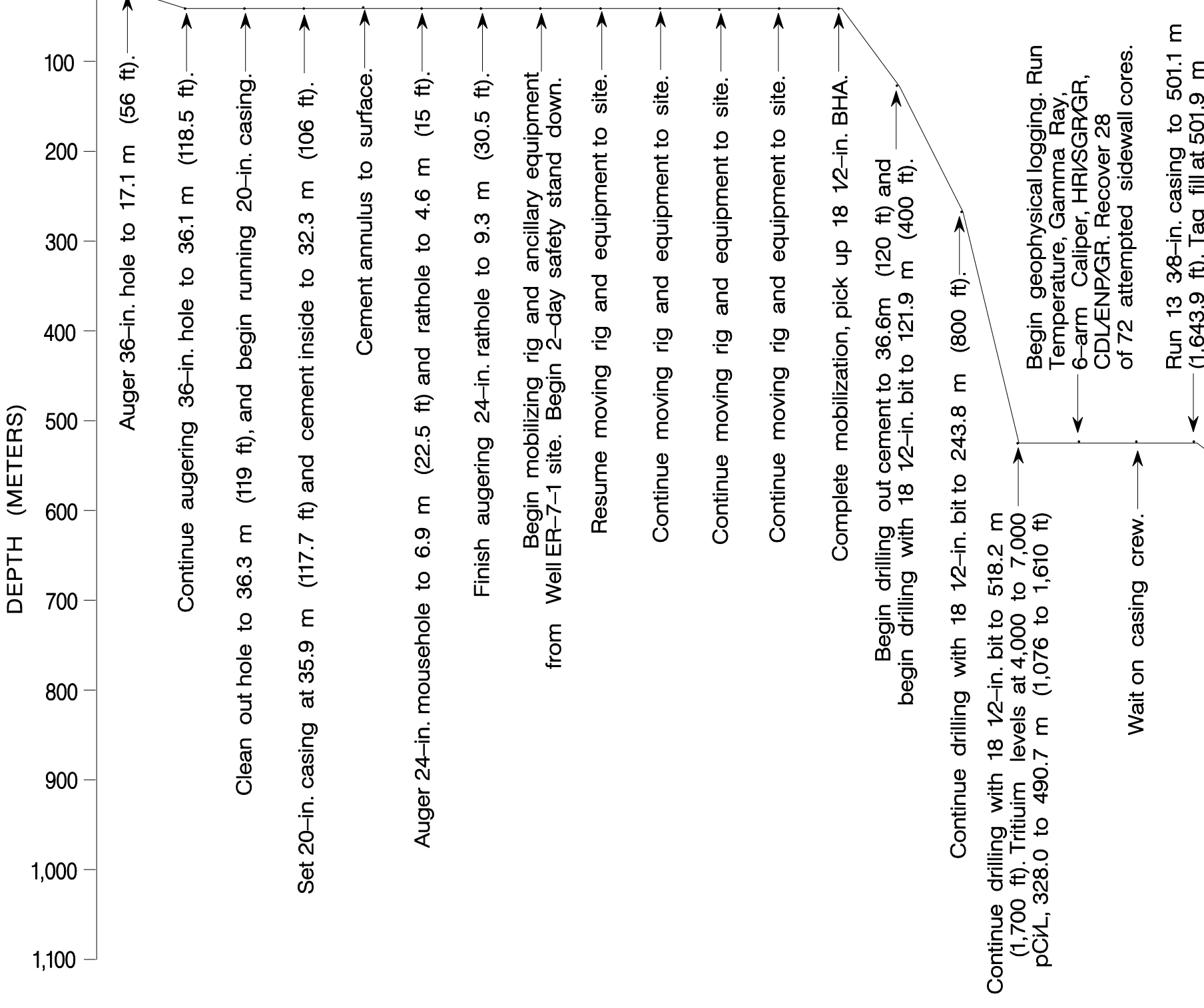

$1,100-$

FIGURE 2-2

WELL ER-2-1

DRILLING AND COMPLETION

HISTORY

SHEET 1 OF 1

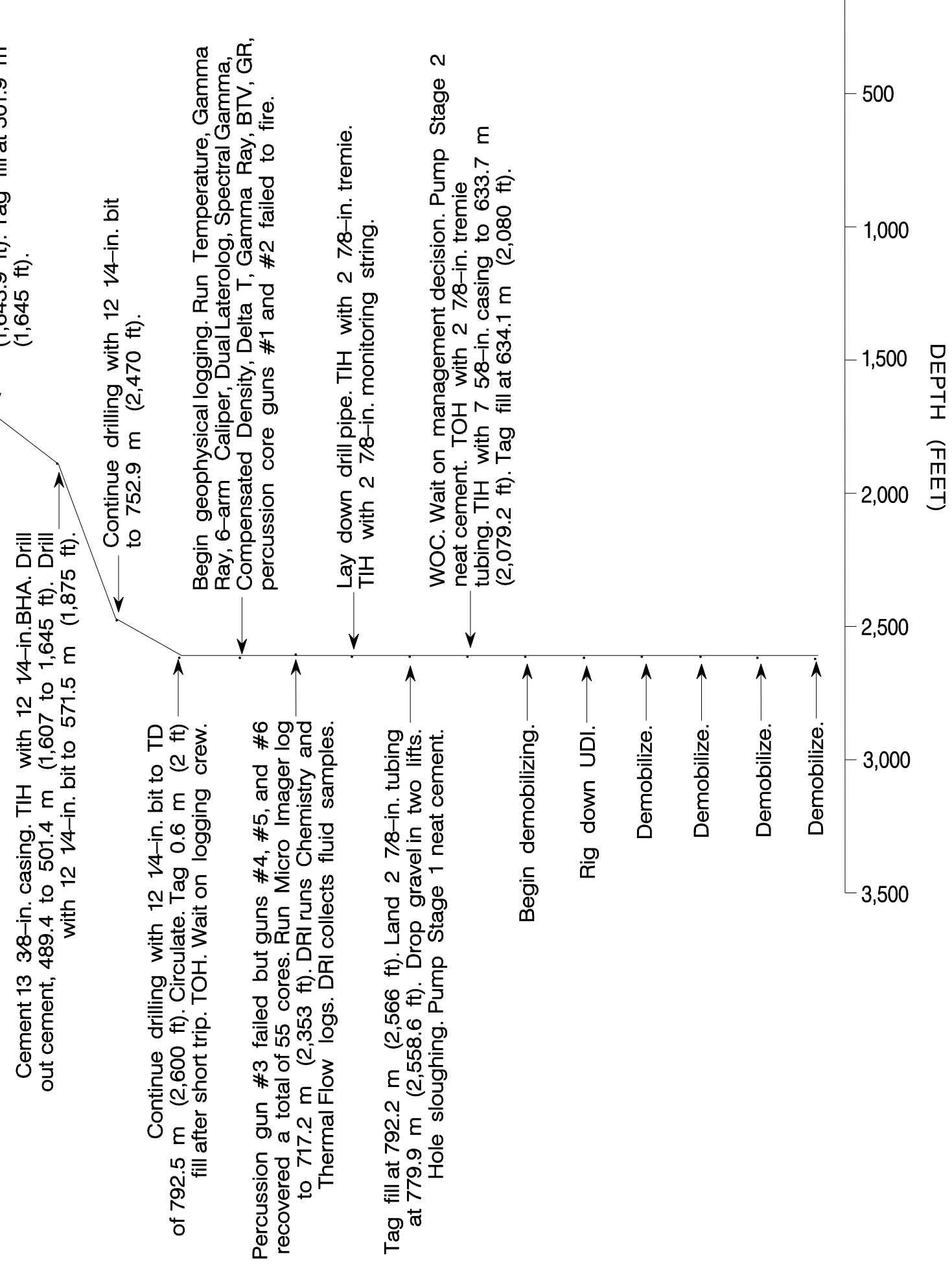


This page intentionally left blank. 


\section{Table 2-1}

\section{Abridged Drill Hole Statistics for Well ER-2-1}

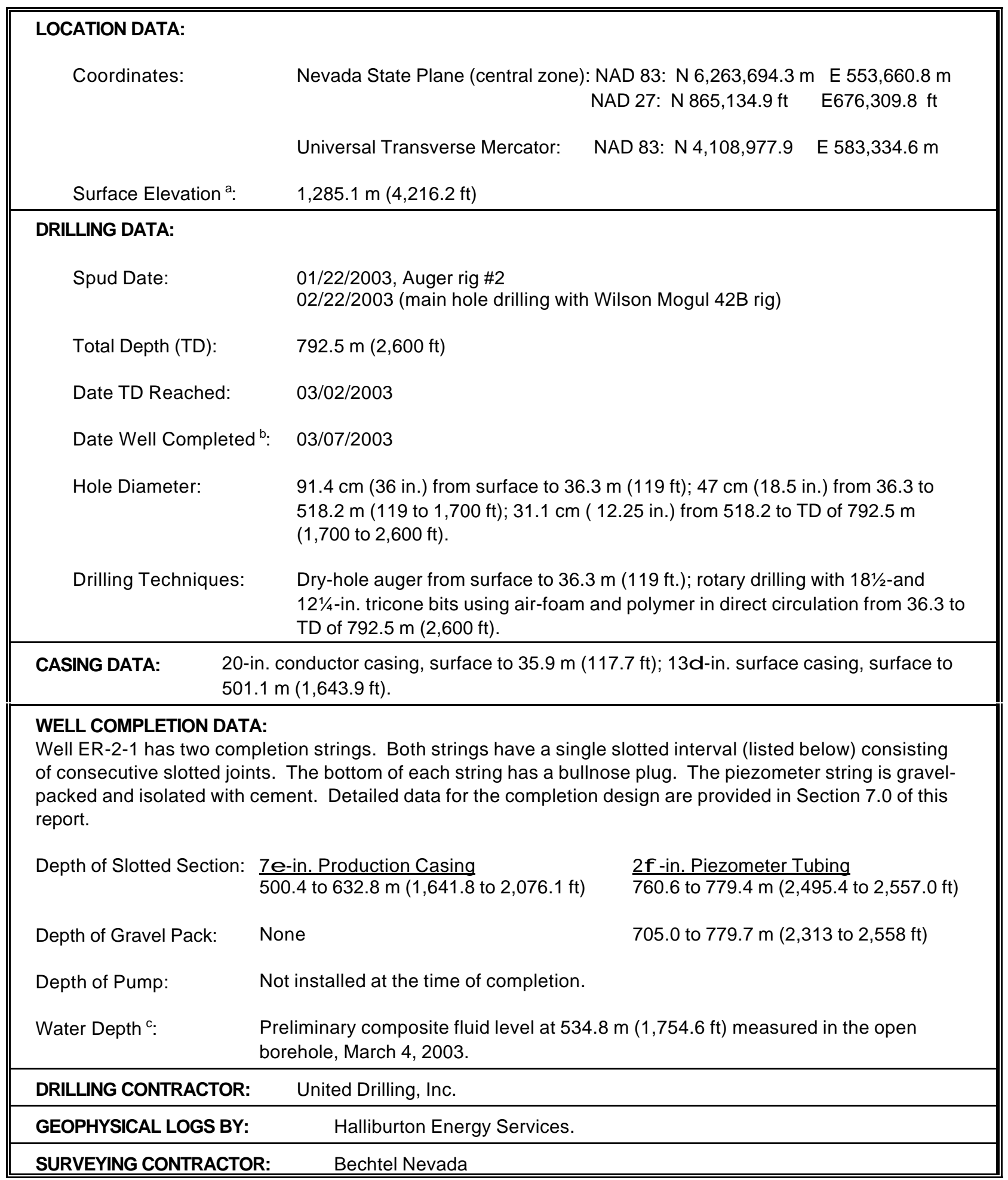

a Elevation of ground level at wellhead. National Geodetic Vertical Datum, 1929.

b Date completion string was cemented. Pump will be installed at a later date, as needed.

c Measured prior to installation of the completion strings. Fluid levels in the borehole rose approximately $138.8 \mathrm{~m}(455.5 \mathrm{ft})$ in the two days after drilling was terminated. 
the drill string off the bottom, and waited about an hour before trying to tag bottom again. Fill was tagged at the depth of $516.0 \mathrm{~m}$ (1,693 ft). The planned geophysical logging of this portion of the borehole was conducted on February 25, 2003.

A casing subcontractor landed $13 \mathrm{~d}$-in. casing that has ribbon stabilizers (centralizers) installed above the float shoe, at the middle and at the top of the first casing joint, and at the top of the second joint. A stab-in float collar was installed between the first and second joints. The casing was landed at a depth of $501.1 \mathrm{~m}(1,643.9 \mathrm{ft})$ on February 25, 2003, about $0.3 \mathrm{~m}(1 \mathrm{ft})$ above $16.8 \mathrm{~m}(55 \mathrm{ft})$ of fill that had accumulated in the bottom of the surface hole prior to and during geophysical logging. After the stab-in sub was seated in the float shoe, the seal was checked by pumping air down the drill pipe. Pre-flush clear water was pumped down the casing and the annulus prior to cementing. Type II neat cement was pumped down 5-in. drill pipe, through the stab-in sub, and followed by flush water to displace the cement into the annulus. The top of cement in the annulus outside the casing was tagged with a tubing string at the depth of approximately $489.8 \mathrm{~m}(1,607 \mathrm{ft})$, and then the annulus was cemented to ground level with Type II neat cement. Cementing of the surface casing was completed on February 28, 2003. The top of cement inside the casing was tagged at $489.8 \mathrm{~m}$ (1,607 ft) when the bottom-hole assembly was lowered back into the hole.

A 121/4-in. bit was used to drill out the cement from 489.8 to $501.4 \mathrm{~m}(1,607$ to $1,645 \mathrm{ft})$, and new borehole was advanced with no problems to the planned TD of $792.5 \mathrm{~m}(2,600 \mathrm{ft})$, reached on March 2, 2003. Water was produced at a rate of 7.6 to $56.8 \mathrm{lpm}$ (2 to $15 \mathrm{gpm}$ ) starting at the depth of about $554.1 \mathrm{~m}(1,818 \mathrm{ft})$. Low levels of tritium $(4,000$ to $7,000 \mathrm{pCi} / \mathrm{L})$ were detected in the drilling fluid returns through the depth interval 743.7 to $765.0 \mathrm{~m}$ (2,440 to 2,510 ft). The standard UGTA suite of geophysical logs was run in the lower portion of the borehole on March 3 and 4, 2003, before the completion strings were installed in the borehole.

The UDI crew on ran a $2 f$-in. tremie line into the borehole on March 5, 2003 and tagged fill at the depth of $782.1 \mathrm{~m}(2,566 \mathrm{ft})$. The $2 \mathrm{f}$-in. monitoring line (piezometer) was then installed and backfilled with gravel and cement, followed by installation of the $7 e$-in. production casing.

The UDI crew was released on March 10, 2003, and they began to rig down to move the drill rig and equipment offsite. 
A borehole deviation survey was conducted on April 27, 2003. Results of this survey shows that at the lowest surveyed depth of $762.0 \mathrm{~m}(2,500 \mathrm{ft})$, the borehole had drifted $1.9 \mathrm{~m}(6.2 \mathrm{ft})$ south and $3.5 \mathrm{~m}$ (11.6 ft) east of the collar location, and that the borehole is relatively straight, with no "doglegs."

A graphical depiction of drilling parameters including penetration rate, rotary revolutions per minute, pump pressure, and weight on the bit is presented in Appendix A-1. See Appendix A-2 for a listing of casing materials. Drilling fluids and cements used in Well ER-2-1 are listed in Appendix A-3.

\subsection{Drilling Problems}

The borehole was advanced to the planned casing point of $518.2 \mathrm{~m}(1,700 \mathrm{ft})$ with no apparent problems, though some fill was noted at a few connections and during logging operations. Also some hole sloughing was experienced during gravel packing and cementing operations of the piezometer string after reaching TD.

\section{$2.4 \quad$ Fluid Management}

Drilling effluent was monitored according to the methods prescribed in the UGTA FMP (DOE/NV, 2002a) and the well-specific Fluid Management Strategy for Well ER-2-1 (Wycoff, 2003). The airfoam/polymer drill fluid was circulated down the inside of the drill string and back up the hole through the annulus (conventional or direct circulation) and then discharged into a sump. Water used to prepare drilling fluids came from a fill pipe at the Area 1 subdock batch plant. This system is supplied by Water Well UE-16d, located on the west side of Yucca Flat. Lithium bromide ( $\mathrm{LiBr})$ was added to the drill fluid as a tracer to provide a means of estimating groundwater production. The rate of water inflow from the borehole was estimated from the dilution of the tracer in the drill fluid returns.

To manage the anticipated water production, two sumps were constructed prior to drilling (Figure 2-1). Radiological contaminants were expected during drilling at this site, so both sumps were lined prior to drilling, by installing 40-millimeter-thick, high-density polyethylene liners, as directed by the NNSA/NSO project manager (Bangerter, 2003).

Samples of drilling effluent were collected hourly and analyzed on site for the presence of tritium by BN Radiation Operations personnel. The onsite monitoring results indicate that tritium was detected while drilling in two intervals. The first measurements above background (less than $8,700 \mathrm{pCi} / \mathrm{L}$ ) were in the vadose zone at 328.9 to $490 \mathrm{~m}$ (1,076 to 1,610 ft). Tritium of similar activity levels was also detected while drilling the saturated zone in the depth interval 743.7 to $765.0 \mathrm{~m}$ (2,440 to 2,510 ft). Tritium 
values remained at or below background levels during drilling of other portions of the borehole. Because it was considered possible that other radionuclides (in addition to tritium) could be encountered, gamma spectroscopy of drill cuttings and fluid samples was conducted at $6.1-\mathrm{m}$ (20-ft) depth intervals while drilling progressed. However, no radionuclides other than tritium, as noted above, were detected (Shaw, 2003).

Drilling fluids generated at Well ER-2-1 were also analyzed every 8 hours for lead, according to the Well ER-2-1 Fluid Management Strategy Letter (Wycoff, 2003). The onsite monitoring results indicate that lead remained at background levels during the entire drilling operation (Shaw, 2003).

Before fluids are discharged from a sump through the overflow pipe, the FMP required that a sample be collected from the sump and analyzed offsite to verify onsite monitoring data and demonstrate compliance with the FMP. However, because of the low water production rate, all fluids were contained in the lined sumps, and composite water samples were not collected from the sumps during drilling of Well ER-2-1 (Shaw, 2003).

All fluid quality objectives were met (Shaw, 2003). The disposition of fluids and solids produced at Well ER-2-1 is presented in the fluid management reporting form dated March 3, 2003 (Appendix B). The form lists volumes of solids (drill cuttings) and fluids produced during well-construction operations, Stages I and II (i.e., vadose- and saturated-zone drilling only; well development and aquifer testing will be conducted at a later date). The volume of solids produced was calculated using the diameter of the borehole (from caliper logs) and the depth drilled, and includes added volume attributed to a rock bulking factor. The volumes of fluids listed on the report are estimates of total fluid production, and do not account for any evaporation of fluids from the sumps.

An early plan was proposed to discharge excess water from the sumps at Well ER-2-1 to nearby crater(s). However, final approval for this disposition was dependent on the execution of a planned crater discharge pilot study. This study has not occurred (as of this writing) and final approval to discharge water from the Well ER-2-1 sumps was never authorized. Consequently, water produced from Well ER-2-1 was not released from the lined sumps. 


\subsection{Geologic Data Collection}

\subsection{Introduction}

This section describes the sources of geologic data obtained from Well ER-2-1 and the methods of data collection. Verifying and enhancing the understanding of the subsurface structure, stratigraphy, and hydrogeology in central Yucca Flat were among the primary objectives of Well ER-2-1, so the proper collection of geologic and hydrogeologic data from the well was considered fundamental to successful completion of the project.

Geologic data collected at Well ER-2-1 consist of drill cuttings, percussion sidewall cores, and geophysical logs. Data collection, sampling, transfer, and documentation activities were performed in accordance with applicable contractor procedures.

\subsection{Collection of Drill Cuttings}

Composite drill cuttings were collected from Well ER-2-1 at 3.05-m (10-ft) intervals as drilling progressed from the bottom of the conductor hole, at the depth of $36.6 \mathrm{~m}(120 \mathrm{ft})$ to the TD of the well at $792.5 \mathrm{~m}$ (2,600 ft). No samples were collected from the interval 109.7 to $112.8 \mathrm{~m}$ (360 to $370 \mathrm{ft}$ ), and minimal material was collected from the interval 630.5 to $606.6 \mathrm{~m}$ (1,980 to 1,990 ft). Triplicate samples were collected from 242 intervals, and in addition, the Shaw field representative collected two sets of reference samples from each of the cuttings intervals. One set was examined at the drill site for use in preparing field lithologic descriptions, and remains in the custody of the current environmental contractor for NNSA/NSO, Stoller-Navarro Joint Venture. The other set was sent to Giday WoldeGabriel (LANL), where it remains. All other samples (i.e., three sets of 242 samples) are stored under secure, environmentally controlled conditions at the U.S. Geological Survey (USGS) Geologic Data Center and Core Library in Mercury, Nevada. One of these sample sets was sealed with custody tape at the rig site and remains sealed as an archive sample; one set was left unsealed in the original sample containers; and the third set was washed and stored according to standard USGS Core Library procedures.

\subsection{Sidewall Core Samples}

Percussion-gun sidewall core samples were collected by Halliburton Energy Services (HES) from Well ER-2-1 on two occasions to verify the stratigraphy and lithology at selected locations. Sample locations were selected by the Shaw field representative on the basis of field lithologic logs (with consideration of borehole conditions determined from caliper logs). Percussion-gun sidewall sampling tools were used to 
collect 28 sidewall cores in the interval 113.7 to $504.1 \mathrm{~m}$ (373 to 1,654 ft) on February 25, 2003, before the surface casing was installed. Percussion-gun sidewall samples were also collected at 55 locations in the interval 635.5 to $741.0 \mathrm{~m}$ (2,085 to 2,431 ft) on March 4, 2003, after the borehole reached the TD of $792.5 \mathrm{~m}$ (2,600 ft). Both sidewall sampling operations were plagued with misfires, and several percussion guns failed completely. Table 3-1 1ists the recovery and stratigraphic assignment for each sample.

\subsection{Sample Analysis}

Twenty-seven samples of drill cuttings from various depths in Well ER-2-1 were submitted to the LANL Earth and Environmental Sciences Division - Geology and Geochemistry laboratories for petrographic, mineralogic, and chemical analyses to aid in stratigraphic identification and for characterization of mineral alteration. All of the planned analyses have been completed, as shown on Table 3-2.

\subsection{Geophysical Logging Data}

Geophysical logs were run in the open borehole to further characterize the lithology, structure, and water content of the rocks encountered. In addition, logs were run to evaluate borehole conditions and to determine the fluid levels during the course of drilling. Geophysical logging was conducted during two stages of drilling: before installation of the surface casing and after the TD was reached (before the completion strings were installed).

The following logs were run in both the air-filled and water-filled portions of the borehole: natural gamma ray, gamma-ray spectroscopy, epithermal neutron porosity, density, six-arm caliper, temperature, and percussion-gun sampling. An induction log was also run in the unsaturated zone, while sonic, spontaneous potential, dual laterolog, and electric micro imaging logs were run in the saturated zone. Desert Research Institute (DRI) personnel also conducted water chemistry and thermal flow logs (see Section 5.3).

The overall quality of the geophysical data collected was good, despite problems with the HES percussion gun tools.

A complete listing of the logs, dates run, depths, and service companies is provided in Table 3-3. The logs are available from BN in Mercury, Nevada, and copies are on file at the office of Stoller-Navarro Joint Venture in Las Vegas, Nevada, and at the USGS Geologic Data Center and Core Library in Mercury, Nevada. Preliminary geophysical data from the logs are reproduced in Appendix D. 
Table 3-1

Sidewall Samples from Well ER-2-1

\begin{tabular}{|c|c|c|c|}
\hline $\begin{array}{l}\text { Core Depth } \\
\text { Meters (Feet) }\end{array}$ & $\begin{array}{c}\text { Recovery } \\
\text { Centimeters } \\
\text { (Inches) } \\
\end{array}$ & Formation & Lithology \\
\hline $113.7(373)$ & $4.8(1.9)$ & \multirow{20}{*}{ Alluvium } & \multirow{20}{*}{ Tuffaceous alluvium } \\
\hline $139.6(458)$ & $4.6(1.8)$ & & \\
\hline $160.3(526)$ & $0.8 \quad(0.3)$ & & \\
\hline $166.4(546)$ & $3.8(1.5)$ & & \\
\hline $189.3(621)$ & $2.5(1.0)$ & & \\
\hline $213.4(700)$ & $4.5(1.8)$ & & \\
\hline $230.7(757)$ & $4.8 \quad(1.9)$ & & \\
\hline $237.7(780)$ & $4.5(1.8)$ & & \\
\hline $285.6 \quad(937)$ & $3.8(1.5)$ & & \\
\hline 293.5 (963) & $3.8(1.5)$ & & \\
\hline $309.1 \quad(1,014)$ & $4.8(1.9)$ & & \\
\hline $321.9(1,056)$ & $3.8(1.5)$ & & \\
\hline $331.9(1,089)$ & $4.6(1.8)$ & & \\
\hline $338.6 \quad(1,111)$ & $4.6(1.8)$ & & \\
\hline $342.6 \quad(1,124)$ & $4.8(1.9)$ & & \\
\hline $351.7 \quad(1,154)$ & $1.0(0.4)$ & & \\
\hline $359.7 \quad(1,180)$ & $4.8(1.9)$ & & \\
\hline $408.1 \quad(1,339)$ & $4.8(1.9)$ & & \\
\hline $419.4 \quad(1,376)$ & $4.3(1.7)$ & & \\
\hline $424.3 \quad(1,392)$ & $4.8(1.9)$ & & \\
\hline $427.9(1,404)$ & $4.8 \quad(1.9)$ & \multirow{3}{*}{ Ammonia Tanks Tuff } & \multirow{3}{*}{ Nonwelded ash-flow tuff } \\
\hline $431.0 \quad(1,414)$ & $4.6(1.8)$ & & \\
\hline $445.0 \quad(1,460)$ & $2.5(1.0)$ & & \\
\hline $451.7 \quad(1,482)$ & $4.5(1.8)$ & \multirow{4}{*}{ bedded Ammonia Tanks Tuff } & \multirow{4}{*}{ Bedded tuff, vitric } \\
\hline $454.5(1,491)$ & $2.5(1.0)$ & & \\
\hline $461.2(1,513)$ & $3.8(1.5)$ & & \\
\hline $466.6 \quad(1,531)$ & $4.6(1.8)$ & & \\
\hline $473.7 \quad(1,554)$ & $3.0(1.2)$ & Rainier Mesa Tuff & Nonwelded ash-flow tuff \\
\hline $525.5 \quad(1,724)$ & $3.0 \quad(1.2)$ & Rainier Mesa Tuff & Partially welded ash-flow tuff \\
\hline
\end{tabular}


Table 3-1

Sidewall Samples from Well ER-2-1 (Page 2 of 3)

\begin{tabular}{|c|c|c|c|}
\hline $\begin{array}{l}\text { Core Depth } \\
\text { Meters (Feet) }\end{array}$ & $\begin{array}{c}\text { Recovery } \\
\text { Centimeters } \\
\text { (Inches) } \\
\end{array}$ & Formation & Lithology \\
\hline $532.2(1,746)$ & $4.2(1.6)$ & \multirow{15}{*}{ Rainier Mesa Tuff } & \multirow{15}{*}{ Nonwelded ash-flow tuff } \\
\hline $534.6(1,754)$ & $4.3 \quad(1.7)$ & & \\
\hline $536.4 \quad(1,760)$ & $2.0(0.8)$ & & \\
\hline $541.3 \quad(1,776)$ & $1.8 \quad(0.7)$ & & \\
\hline $542.5(1,780)$ & $1.3(0.5)$ & & \\
\hline $544.4 \quad(1,786)$ & $4.3(1.7)$ & & \\
\hline $549.2(1,802)$ & $2.0(0.8)$ & & \\
\hline $552.6 \quad(1,813)$ & $4.3 \quad(1.7)$ & & \\
\hline $552.6 \quad(1,813)$ & $4.6 \quad(1.9)$ & & \\
\hline $554.1(1818)$ & $4.8 \quad(1.9)$ & & \\
\hline $555.3 \quad(1,822)$ & $4.3(1.7)$ & & \\
\hline $557.8 \quad(1,830)$ & $4.5(1.8)$ & & \\
\hline $565.4 \quad(1,855)$ & $4.3 \quad(1.7)$ & & \\
\hline $567.8 \quad(1,863)$ & $4.5(1.8)$ & & \\
\hline $570.0 \quad(1,870)$ & $4.3 \quad(1.7)$ & & \\
\hline $579.7 \quad(1,902)$ & $3.6 \quad(1.4)$ & \multirow{2}{*}{ Tuff of Holmes Road } & \multirow{2}{*}{ Bedded tuff, vitric } \\
\hline $583.1 \quad(1,913)$ & $5.1 \quad(2.0)$ & & \\
\hline $588.3 \quad(1,930)$ & $4.2(1.6)$ & \multirow{3}{*}{ Tuff of Holmes Road } & \multirow{3}{*}{ Bedded tuff, zeolitic } \\
\hline $591.3 \quad(1,940)$ & $2.5(1.0)$ & & \\
\hline $593.1 \quad(1,946)$ & $3.6(1.4)$ & & \\
\hline $597.4 \quad(1,960)$ & $2.8(1.1)$ & \multirow{6}{*}{$\begin{array}{l}\text { Pre-Rainier Mesa tuffs, } \\
\text { undifferentiated }\end{array}$} & \multirow{6}{*}{ Bedded tuff, zeolitic } \\
\hline $602.3 \quad(1,976)$ & $4.8 \quad(1.9)$ & & \\
\hline $605.9(1,988)$ & $4.5(1.8)$ & & \\
\hline $606.2(1,989)$ & $3.3(1.3)$ & & \\
\hline $609.6(2,000)$ & $4.6(1.8)$ & & \\
\hline $612.0 \quad(2,008)$ & $3.0(1.2)$ & & \\
\hline $615.7 \quad(2020)$ & $1.8(0.7)$ & \multirow{3}{*}{ Calico Hills Formation } & \multirow{3}{*}{ Bedded tuff, zeolitic } \\
\hline $620.6 \quad(2,036)$ & $2.0(0.8)$ & & \\
\hline $626.1 \quad(2,054)$ & $2.0(0.8)$ & & \\
\hline
\end{tabular}


Table 3-1

Sidewall Samples from Well ER-2-1 (Page 3 of 3)

\begin{tabular}{|c|c|c|c|}
\hline $\begin{array}{l}\text { Core Depth } \\
\text { Meters } \quad \text { (Feet) }\end{array}$ & $\begin{array}{c}\text { Recovery } \\
\text { Centimeters } \\
\text { (Inches) }\end{array}$ & Formation & Lithology \\
\hline $639.8 \quad(2,099)$ & $4.8(1.9)$ & \multirow{3}{*}{ Tuff of Wahmonie Flat } & \multirow{3}{*}{ Bedded tuff, zeolitic, mafic-rich } \\
\hline $640.7 \quad(2,102)$ & $3.6(1.4)$ & & \\
\hline $640.7 \quad(2,102)$ & $3.6(1.4)$ & & \\
\hline $645.6(2,118)$ & $4.6(1.8)$ & \multirow{16}{*}{ Crater Flat Tuff } & \multirow{16}{*}{ Bedded tuff, zeolitic } \\
\hline $650.1 \quad(2,133)$ & $4.2(1.6)$ & & \\
\hline $661.4 \quad(2,170)$ & $4.3(1.7)$ & & \\
\hline $664.5(2,180)$ & $4.5(1.8)$ & & \\
\hline $668.7 \quad(2,194)$ & 3.8 (1.5) & & \\
\hline $669.3 \quad(2,196)$ & $3.6(1.4)$ & & \\
\hline $669.7 \quad(2,196)$ & $4.1(1.6)$ & & \\
\hline $673.0(2,208)$ & $3.0(1.2)$ & & \\
\hline $676.7(2,220)$ & $4.3(1.7)$ & & \\
\hline $683.1 \quad(2,241)$ & $4.8(1.9)$ & & \\
\hline $687.0(2,254)$ & $3.6(1.4)$ & & \\
\hline $687.0(2,254)$ & 3.3 (1.3) & & \\
\hline $689.8 \quad(2,263)$ & 4.8 (1.9) & & \\
\hline $691.3(2,268)$ & $2.5(1.0)$ & & \\
\hline $699.2(2,294)$ & $4.8(1.9)$ & & \\
\hline $706.2(2,317)$ & $4.8(1.9)$ & & \\
\hline $709.6 \quad(2,328)$ & $4.8(1.9)$ & \multirow{3}{*}{ Grouse Canyon Tuff } & \multirow{3}{*}{ Air-fall Tuff, peralkaline, zeolitic } \\
\hline $716.0 \quad(2,349)$ & $4.8(1.9)$ & & \\
\hline $720.2(2,363)$ & $4.1 \quad(1.6)$ & & \\
\hline $730.9 \quad(2,398)$ & $4.8(1.9)$ & \multirow{3}{*}{ Tunnel Formation, bed 4k } & \multirow{3}{*}{ Bedded tuff, zeolitic } \\
\hline $735.8 \quad(2,414)$ & $4.8 \quad(1.9)$ & & \\
\hline $741.0 \quad(2,431)$ & $2.0(0.8)$ & & \\
\hline
\end{tabular}

a All samples are wireline percussion-gun sidewall cores collected by Halliburton Energy Services on February 25 and March 3-4, 2003. 
Table 3-2

Status of Rock Sample Analyses for Well ER-2-1

\begin{tabular}{|c|c|c|c|c|c|}
\hline \multirow{3}{*}{$\begin{array}{c}\text { Depth }^{\mathbf{a}} \\
\text { meters (feet) }\end{array}$} & \multicolumn{5}{|c|}{ Analyses Performed $^{c}$} \\
\hline & \multirow{2}{*}{$\begin{array}{c}\text { Petrographic } \\
\text { PTS } \\
\end{array}$} & \multicolumn{2}{|c|}{ Mineralogic } & \multicolumn{2}{|c|}{ Chemical } \\
\hline & & $\mathrm{MP}$ & XRD & XRF & $\mathrm{Fe}^{2+} / \mathrm{Fe}^{3+}$ \\
\hline $73.2(240)$ & $\mathrm{C}$ & $\mathrm{N} / \mathrm{P}$ & $\mathrm{C}$ & $\mathrm{N} / \mathrm{P}$ & $\mathrm{N} / \mathrm{P}$ \\
\hline $359.7(1,180)$ & C & $\mathrm{N} / \mathrm{P}$ & $\mathrm{C}$ & $\mathrm{N} / \mathrm{P}$ & $\mathrm{N} / \mathrm{P}$ \\
\hline $426.7(1,400)$ & C & $\mathrm{N} / \mathrm{P}$ & C & $\mathrm{N} / \mathrm{P}$ & $\mathrm{N} / \mathrm{P}$ \\
\hline $438.9(1,440)$ & C & $\mathrm{N} / \mathrm{P}$ & C & C & C \\
\hline $451.1(1,480)$ & $\mathrm{C}$ & $\mathrm{N} / \mathrm{P}$ & $\mathrm{C}$ & $\mathrm{N} / \mathrm{P}$ & $\mathrm{N} / \mathrm{P}$ \\
\hline $484.6(1,590)$ & $\mathrm{C}$ & $\mathrm{N} / \mathrm{P}$ & $\mathrm{C}$ & $\mathrm{N} / \mathrm{P}$ & $\mathrm{N} / \mathrm{P}$ \\
\hline $493.8(1,620)$ & C & $\mathrm{N} / \mathrm{P}$ & C & C & C \\
\hline $509.0(1,670)$ & $\mathrm{C}$ & $\mathrm{N} / \mathrm{P}$ & $\mathrm{C}$ & $\mathrm{C}$ & $\mathrm{C}$ \\
\hline $521.2(1,710)$ & $\mathrm{C}$ & $\mathrm{N} / \mathrm{P}$ & $\mathrm{C}$ & $\mathrm{N} / \mathrm{P}$ & $\mathrm{N} / \mathrm{P}$ \\
\hline $542.5(1,780)$ & C & $\mathrm{N} / \mathrm{P}$ & C & $\mathrm{N} / \mathrm{P}$ & $\mathrm{N} / \mathrm{P}$ \\
\hline $576.1(1,890)$ & $\mathrm{C}$ & $\mathrm{N} / \mathrm{P}$ & C & C & C \\
\hline $594.4(1,950)$ & C & C & C & C & C \\
\hline $621.8(2,040) \mathrm{A}$ & $\mathrm{C}$ & $\mathrm{N} / \mathrm{P}$ & $\mathrm{C}$ & $\mathrm{C}$ & $\mathrm{C}$ \\
\hline $621.8(2,040) \mathrm{B}$ & C & $\mathrm{N} / \mathrm{P}$ & C & C & C \\
\hline $640.1(2,100) \mathrm{A}$ & $\mathrm{C}$ & $\mathrm{N} / \mathrm{P}$ & $\mathrm{C}$ & $\mathrm{C}$ & $\mathrm{C}$ \\
\hline $640.1(2,100) \mathrm{B}$ & C & $\mathrm{N} / \mathrm{P}$ & C & C & $\mathrm{C}$ \\
\hline $652.3(2,140)$ & C & $\mathrm{N} / \mathrm{P}$ & C & $\mathrm{N} / \mathrm{P}$ & $\mathrm{N} / \mathrm{P}$ \\
\hline $664.5(2,180)$ & $\mathrm{C}$ & $\mathrm{N} / \mathrm{P}$ & $\mathrm{C}$ & C & C \\
\hline $670.6(2,200)$ & C & C & C & $\mathrm{N} / \mathrm{P}$ & $\mathrm{N} / \mathrm{P}$ \\
\hline $682.8(2,240)$ & $\mathrm{C}$ & $\mathrm{N} / \mathrm{P}$ & $\mathrm{C}$ & $\mathrm{N} / \mathrm{P}$ & $\mathrm{N} / \mathrm{P}$ \\
\hline $707.1(2,320)$ & $\mathrm{C}$ & $\mathrm{N} / \mathrm{P}$ & $\mathrm{C}$ & $\mathrm{N} / \mathrm{P}$ & $\mathrm{N} / \mathrm{P}$ \\
\hline $713.2(2,340)$ & C & $\mathrm{N} / \mathrm{P}$ & $\mathrm{C}$ & $\mathrm{N} / \mathrm{P}$ & $\mathrm{N} / \mathrm{P}$ \\
\hline $722.4(2,370)$ & $\mathrm{C}$ & $\mathrm{N} / \mathrm{P}$ & $\mathrm{C}$ & $\mathrm{C}$ & $\mathrm{C}$ \\
\hline $737.6(2,420)$ & $\mathrm{C}$ & $\mathrm{N} / \mathrm{P}$ & $\mathrm{C}$ & $\mathrm{N} / \mathrm{P}$ & $\mathrm{N} / \mathrm{P}$ \\
\hline $762.0(2,500)$ & C & $\mathrm{N} / \mathrm{P}$ & C & $\mathrm{N} / \mathrm{P}$ & $\mathrm{N} / \mathrm{P}$ \\
\hline $768.1(2,520)$ & $\mathrm{C}$ & $\mathrm{C}$ & $\mathrm{C}$ & $\mathrm{C}$ & C \\
\hline $792.5(2,600)$ & $\mathrm{C}$ & $\mathrm{C}$ & $\mathrm{C}$ & $\mathrm{C}$ & $\mathrm{C}$ \\
\hline
\end{tabular}

a Depth represents base of 3.0-m (10-ft) sample interval for drill cuttings. All samples are drill cuttings that represent the lithologic character of the interval.

b Status of analyses at the time of this writing: $\mathbf{C}=$ analysis complete; $\mathbf{N} / \mathbf{P}=$ analysis not planned.

Analysis type: $\mathbf{P T S}=$ polished thin section; $\mathbf{M P}=$ electron microprobe; $\mathbf{X R D}=\mathrm{x}$-ray diffraction;

$\mathrm{XRF}=\mathrm{X}$-ray fluorescence; $\mathrm{Fe}^{2+} / \mathrm{Fe}^{3+}=$ wet chemical analysis for iron. 
Table 3-3

Well ER-2-1 Geophysical Log Summary

\begin{tabular}{|c|c|c|c|c|c|c|}
\hline Geophysical Log Type ${ }^{a}$ & Log Purpose & $\begin{array}{l}\text { Logging } \\
\text { Service } b\end{array}$ & $\begin{array}{l}\text { Date } \\
\text { Logged }\end{array}$ & Run Number & $\begin{array}{l}\text { Bottom of } \\
\text { Logged } \\
\text { Interval }^{c} \\
\text { meters (feet) }\end{array}$ & $\begin{array}{l}\text { Top of Logged } \\
\text { Interval c } \\
\text { meters (feet) }\end{array}$ \\
\hline * Natural Gamma Ray Spectroscopy & $\begin{array}{l}\text { Stratigraphic correlation, mineralogy, } \\
\text { natural and man-made radiation }\end{array}$ & HES & $\begin{array}{l}02 / 25 / 2003 \\
03 / 03 / 2003\end{array}$ & $\begin{array}{l}\text { SGR-1/GR-3 } \\
\text { SGR-2 }\end{array}$ & $\begin{array}{r}499.6(1,639) \\
756.2(2,481)\end{array}$ & $\begin{array}{c}12.8(42) \\
487.7(1,600)\end{array}$ \\
\hline * Six Arm Caliper / Gamma Ray & $\begin{array}{l}\text { Borehole conditions, cement volume } \\
\text { calculation / stratigraphic correlation }\end{array}$ & HES & $\begin{array}{l}02 / 25 / 2003 \\
03 / 03 / 2003 \\
03 / 03 / 2003\end{array}$ & $\begin{array}{l}\text { CA6-1/ GR-2 } \\
\text { CA6-2/ SGR-6 } \\
\text { CA6-3/ GR-10 }\end{array}$ & $\begin{array}{l}508.4(1,668) \\
766.0(2,513) \\
713.5(2,341)\end{array}$ & $\begin{array}{c}25.0(82) \\
426.7(1,400) \\
487.7(1,600)\end{array}$ \\
\hline * High Resolution Induction Log & $\begin{array}{l}\text { Lithologic determination /borehole } \\
\text { conditions / stratigraphic correlation }\end{array}$ & HES & $02 / 25 / 2003$ & HRI1/ GR-3 & $509.0(1,670)$ & $36.0(118)$ \\
\hline *Dual Laterolog & $\begin{array}{l}\text { Lithologic determination / borehole } \\
\text { conditions / stratigraphic correlation }\end{array}$ & HES & $03 / 03 / 2003$ & DLL-1/SP-1/GR-7 & $764.4(2,508)$ & $635.5(2,085)$ \\
\hline $\begin{array}{l}\text { *Epithermal Neutron / Density / } \\
\text { Gamma Ray }\end{array}$ & $\begin{array}{l}\text { Total water content / rock porosity / } \\
\text { stratigraphic correlation / borehole } \\
\text { conditions }\end{array}$ & HES & $\begin{array}{l}02 / 25 / 2003 \\
03 / 03 / 2003\end{array}$ & $\begin{array}{c}\text { DSEN-1/SDL-1/GR- } \\
4 \\
\text { DSEN-2/SDL-2/GR- } \\
8\end{array}$ & $\begin{array}{l}510.5(1,675) \\
761.4(2,498)\end{array}$ & $\begin{array}{c}18.3(60) \\
487.7(1,600)\end{array}$ \\
\hline Electric Micro Imager & $\begin{array}{l}\text { Saturated zone: lithologic } \\
\text { characterization, fracture and void } \\
\text { analysis. }\end{array}$ & HES & $\begin{array}{l}03 / 02 / 2003 \\
03 / 02 / 2003\end{array}$ & $\begin{array}{l}\text { EMI-1/CA6-3/GR-6 } \\
\text { EMI-2/GR-10 }\end{array}$ & $\begin{array}{l}766.9(2,516) \\
622.1(2,041)\end{array}$ & $\begin{array}{l}519.7(1,705) \\
519.7(1,705)\end{array}$ \\
\hline Temperature / Gamma Ray & $\begin{array}{l}\text { Saturated zone: groundwater } \\
\text { temperature / stratigraphic correlation }\end{array}$ & HES & $\begin{array}{l}02 / 25 / 2003 \\
03 / 03 / 2003 \\
03 / 04 / 2003\end{array}$ & $\begin{array}{c}\text { TL-1/GR-1 } \\
\text { TL-2/GR-5 } \\
\text { TL-3/Chem-1 }\end{array}$ & $\begin{array}{l}496.2(1,628) \\
754.7(2,476) \\
716.9(2,352)\end{array}$ & $\begin{array}{c}21.9(72) \\
304.8(1,000) \\
535.2(1,756)\end{array}$ \\
\hline $\begin{array}{l}\text { Percussion Gun Sidewall Tool / } \\
\text { Gamma Ray }\end{array}$ & Geologic samples & HES & $\begin{array}{l}02 / 25 / 2003 \\
03 / 04 / 2003\end{array}$ & $\begin{array}{l}\text { RSWC-1-3 } \\
\text { RSWC-4-6 }\end{array}$ & $\begin{array}{l}504.1(1,654) \\
752.2(2,468)\end{array}$ & $\begin{array}{c}113.7(373) \\
521.2(1,710)\end{array}$ \\
\hline Thermal Flow Meter & Flow direction, rate within borehole & DRI & $03 / 04 / 03$ & TFM-1 & $672.1(2,205)$ & $579.1(1,900)$ \\
\hline * Chemistry / Temperature Log & $\begin{array}{l}\text { Groundwater chemistry and } \\
\text { temperature, formation transmissivity }\end{array}$ & DRI & $03 / 04 / 2003$ & Chem-1/Temp-3 & $716.9(2,352)$ & $535.2(1,756)$ \\
\hline Long Spaced Sonic Delta-T & $\begin{array}{l}\text { Saturated zone: lithologic } \\
\text { characterization, porosity, fracture and } \\
\text { void analysis. }\end{array}$ & HES & $03 / 03 / 2003$ & FWS-1/GR-9 & $755.6(2,479)$ & $602.3(1,976)$ \\
\hline Full Wave Sonic Waveform & $\begin{array}{l}\text { Saturated zone: lithologic } \\
\text { characterization, porosity, fracture and } \\
\text { void analysis. }\end{array}$ & HES & $03 / 03 / 2003$ & FWS-1/GR-9 & $755.6(2,479)$ & $602.3(1,976)$ \\
\hline Gyroscopic Directional Survey & Borehole deviation & BHI. & $04 / 27 / 2003$ & DRG & $762.0(2,500)$ & 0 \\
\hline
\end{tabular}

a Logs presented in geophysical log summary, Appendix D, are indicated by *.

c Depth below ground surface.

b $\mathrm{HES}=$ Halliburton Energy Services; DRI = Desert Research Institute; $\mathrm{BHI}=$ Baker Hughes Inteq 
This page intentionally left blank. 


\subsection{Geology and Hydrogeology}

\subsection{Introduction}

This section summarizes the geology and hydrogeology of Well ER-2-1. The detailed lithology log, presented in Appendix C, was developed using drill cuttings, sidewall core samples, geophysical logs, and drilling parameter data. Stratigraphic assignments are based on correlation with other Yucca Flat drill holes using Southern Nevada Volcanic Field stratigraphic nomenclature as presented in Warren et al. (2000). Identifications of alteration mineralogy presented here are based primarily on mineralogic and chemical data and interpretations provided by G. WoldeGabriel of LANL (WoldeGabriel et al., 2003). See Table 3-2 for a list of laboratory analyses conducted at LANL on samples from Well ER-2-1.

\subsection{Geology}

This section is subdivided into discussions of the general geologic setting, stratigraphy, and structural features interpreted from Well ER-2-1 data, and a discussion of alteration noted in samples from the borehole.

The geology of the Well ER-2-1 area was fairly well known and based on the geology encountered at nearby emplacement and related exploratory holes (Gonzales and Drellack, 1999; Pawloski, 1985; Howard, 1977; Tewhey, 1975; McKague, 1973).

\subsubsection{Geologic Setting}

The Well ER-2-1 site is located in north-central Yucca Flat, a hydrographically closed basin that is bounded on all sides by low hills and ranges of volcanic and sedimentary rocks (Figure 4-1). The subsurface geology of Yucca Flat is dominated by Tertiary-age volcanic rocks, consisting mainly of ashflow tuffs with interbedded nonwelded and bedded tuffs. The tuffs are overlain by younger alluvial sediment eroded from the surrounding mountains. These basin-fill rocks and sediments are cut by northsouth-trending, mostly down-to-the-east, high-angle normal faults (e.g., Yucca and Carpetbag faults) related to Basin and Range extension (Byers et al., 1976).

The Oak Spring and Yucca Flat geologic quadrangle maps (Barnes et al., 1963; Colton and McKay, 1966) depict the relatively simple surface geology of this part of Yucca Flat, where Well ER-2-1 is sited on alluvial valley-fill material. Ash-flow tuffs assigned to the Timber Mountain Group outcrop 3.6 kilometers (2.2 miles) to the east, in the vicinity of Balloon Hill (Slate et al., 1999). Paleozoic-age rocks of the Bonanza King and Wood Canyon Formations are 
This page intentionally left blank.

4-2 


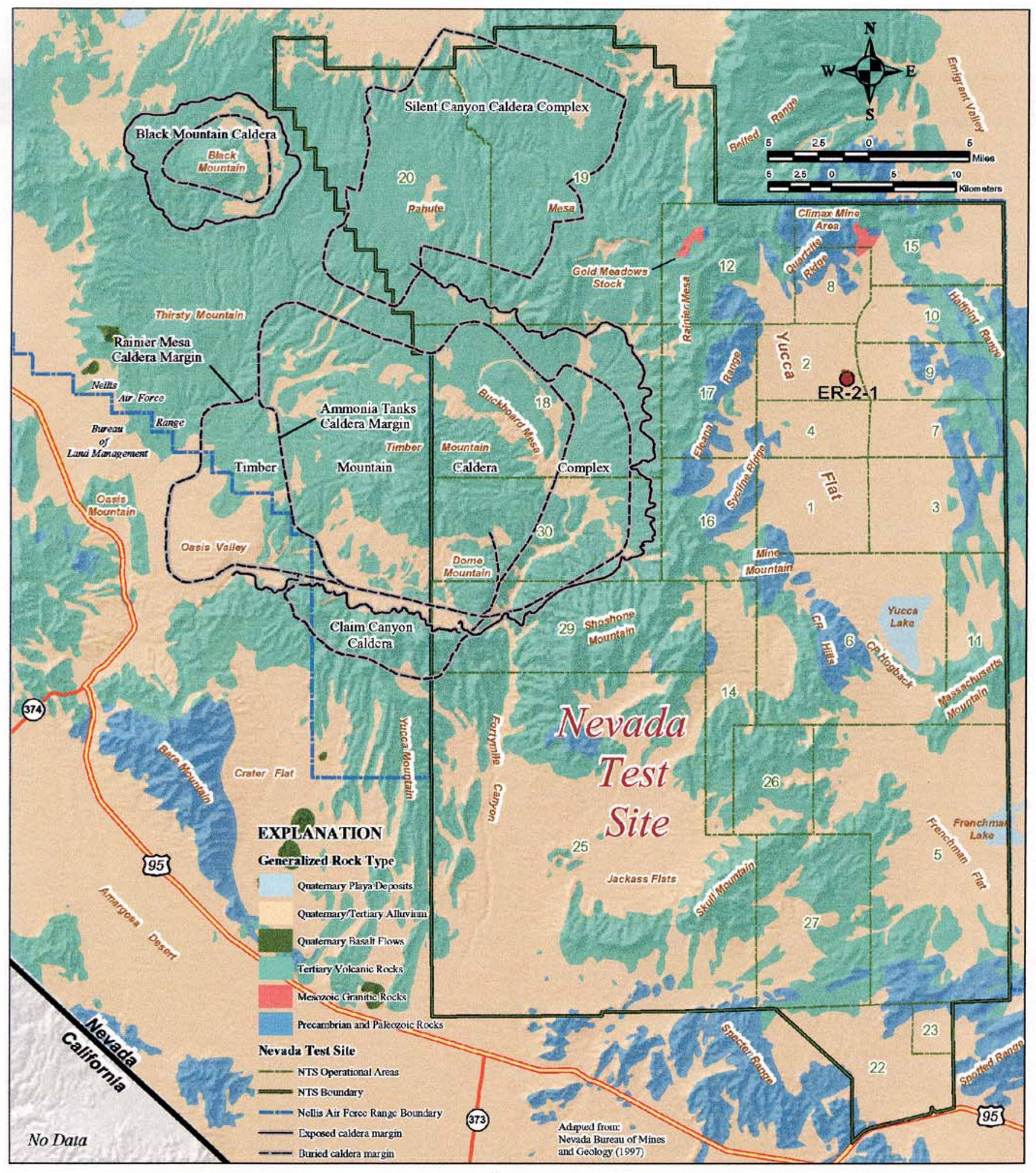

Figure 4-1

Generalized Surface Geologic Map of the Nevada Test Site Area Showing Location of Well ER-2-1 
This page intentionally left blank.

4-4 
exposed at Banded Mountain, about 4.2 kilometers (2.6 miles) to the east-northeast. See Table A.4-1 in the Yucca Flat drilling criteria document (IT, 2002) for a full list of possible stratigraphic units present in the Well ER-2-1 area.

The surface deposits at ER-2-1 are typical of the flood plain alluvium mapped in lateral to median locations of Yucca Flat (Figure 4-2). The sediments are composed of poorly to moderately sorted gravel, sand, and silt, with less than 50 percent (by volume) gravel-size fragments.

\subsubsection{Stratigraphy and Structure}

The relative thicknesses of stratigraphic units and positions of faults in the vicinity of Well ER-2-1 are shown on Figures 4-3 and 4-4, which are west-east and north-south geologic cross sections, respectively, through Well ER-2-1. The transects of these cross sections are shown in Figure 4-2.

From the surface, the hole penetrated Quaternary alluvial deposits which are about $425.2 \mathrm{~m}(1,395 \mathrm{ft})$ thick. The Ammonia Tanks Tuff underlies the alluvium here, and consists of an upper nonwelded ashflow tuff $22.9 \mathrm{~m}$ (75 ft) thick and a lower vitric, bedded tuff unit (bedded Ammonia Tanks tuff) $21.9 \mathrm{~m}$ (72 ft) thick. Nonwelded to densely welded, vitric to devitrified, ash-flow tuff of the Rainier Mesa Tuff in the 470.0 to $577.6 \mathrm{~m}$ (1,542 to $1,895 \mathrm{ft}$ ) depth interval was drilled next. The Rainier Mesa Tuff is about $107.6 \mathrm{~m}$ (353 ft) thick, and in this part of Yucca Flat there is a vitrophyre about $26.8 \mathrm{~m}(88 \mathrm{ft})$ below the top of the unit.

Below the Rainier Mesa Tuff Well ER-2-1 penetrated a 214.9-m (705-ft) thick sequence of bedded tuffs typical of central Yucca Flat. In some parts of Yucca Flat these rocks cannot be subdivided into their respective stratigraphic units, but are "lumped" into informal units between marker beds. The upper portion of the sequence consists of the Tuff of Holmes Road, Paintbrush Group, and the Calico Hills Formation, and is referred to as the pre-Rainier Mesa, post-Wahmonie tuffs. The base of this lumping unit is the Tuff of Wahmonie Flat, a mafic-rich marker bed in the Wahmonie Formation, which is about $13.7 \mathrm{~m}$ (45 ft) thick at Well ER-2-1. Below the Tuff of Wahmonie Flat are $62.5 \mathrm{~m}$ (205 ft) of bedded tuffs related to the Crater Flat Group. Below the Crater Flat tuffs is another marker bed, the Grouse Canyon Tuff. This pumice-rich peralkaline air-fall tuff is about $15.2 \mathrm{~m}(50 \mathrm{ft})$ thick at Well ER-2-1. The deepest units penetrated by this hole are bedded and nonwelded tuffs assigned to the Tunnel Formation, 4 Member, with a thickness of more than $70.1 \mathrm{~m}(230 \mathrm{ft})$. 
This page intentionally left blank. 


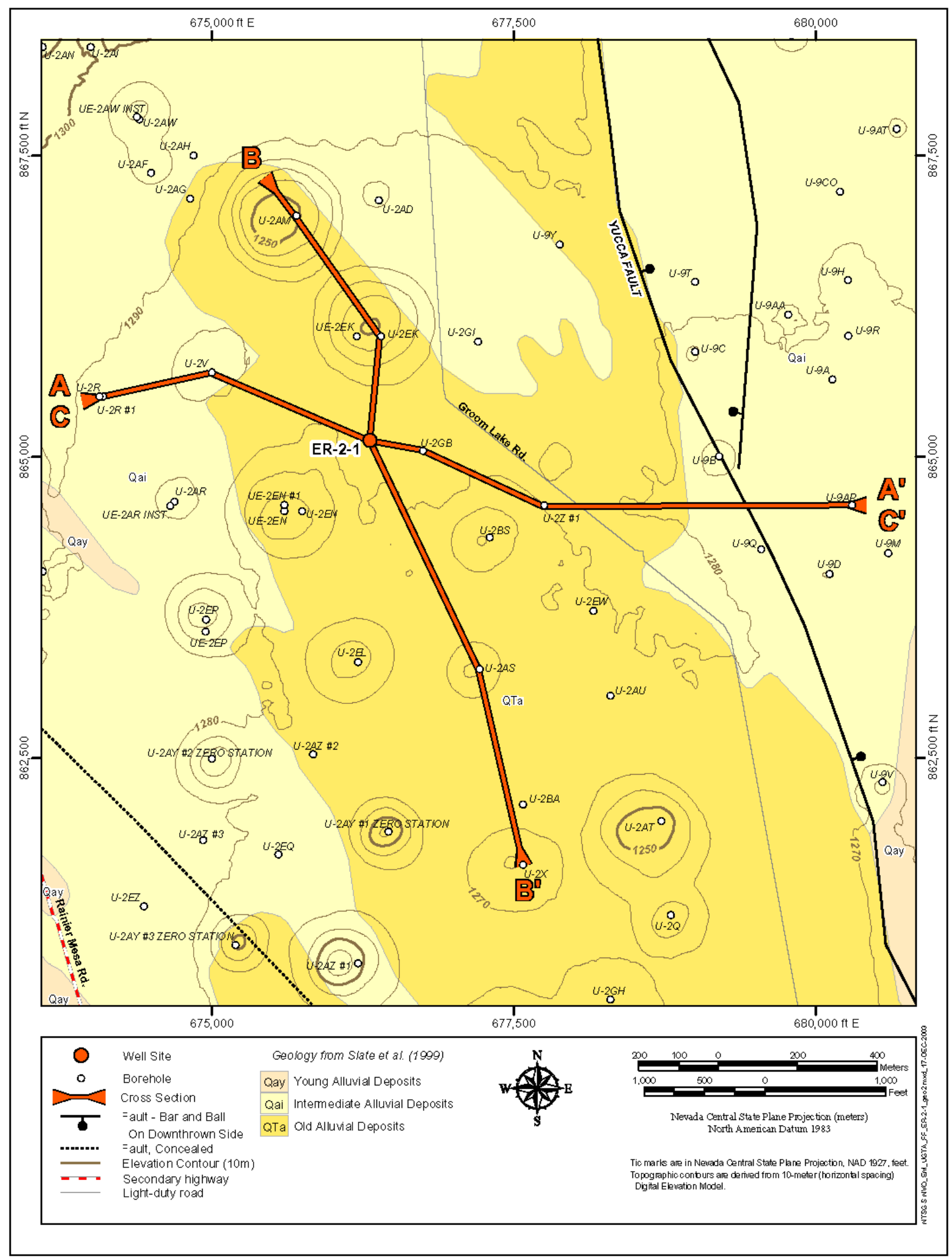

Figure 4-2

Surface Geologic Map of the Well ER-2-1 Site 
This page intentionally left blank.

4-8 


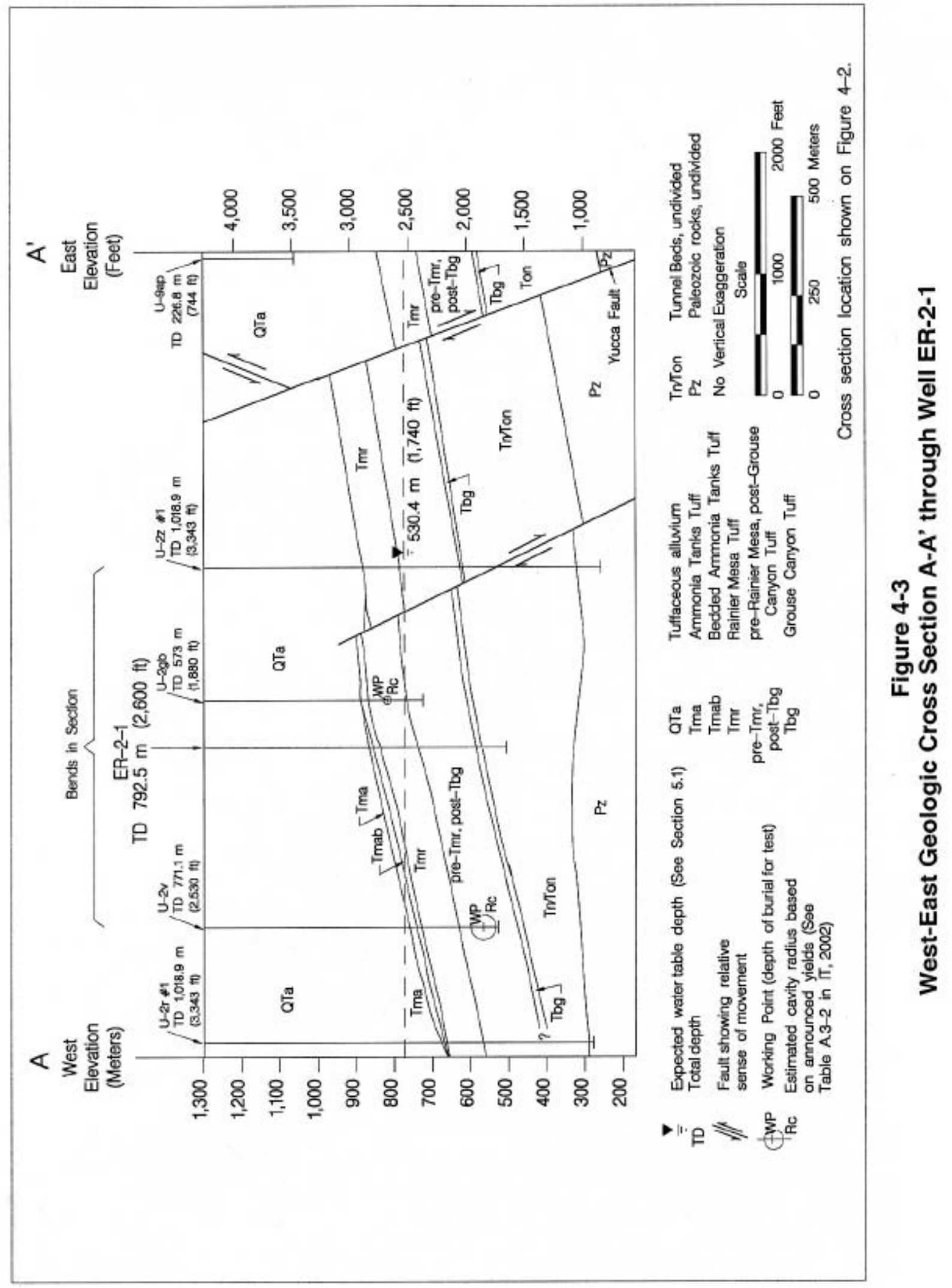




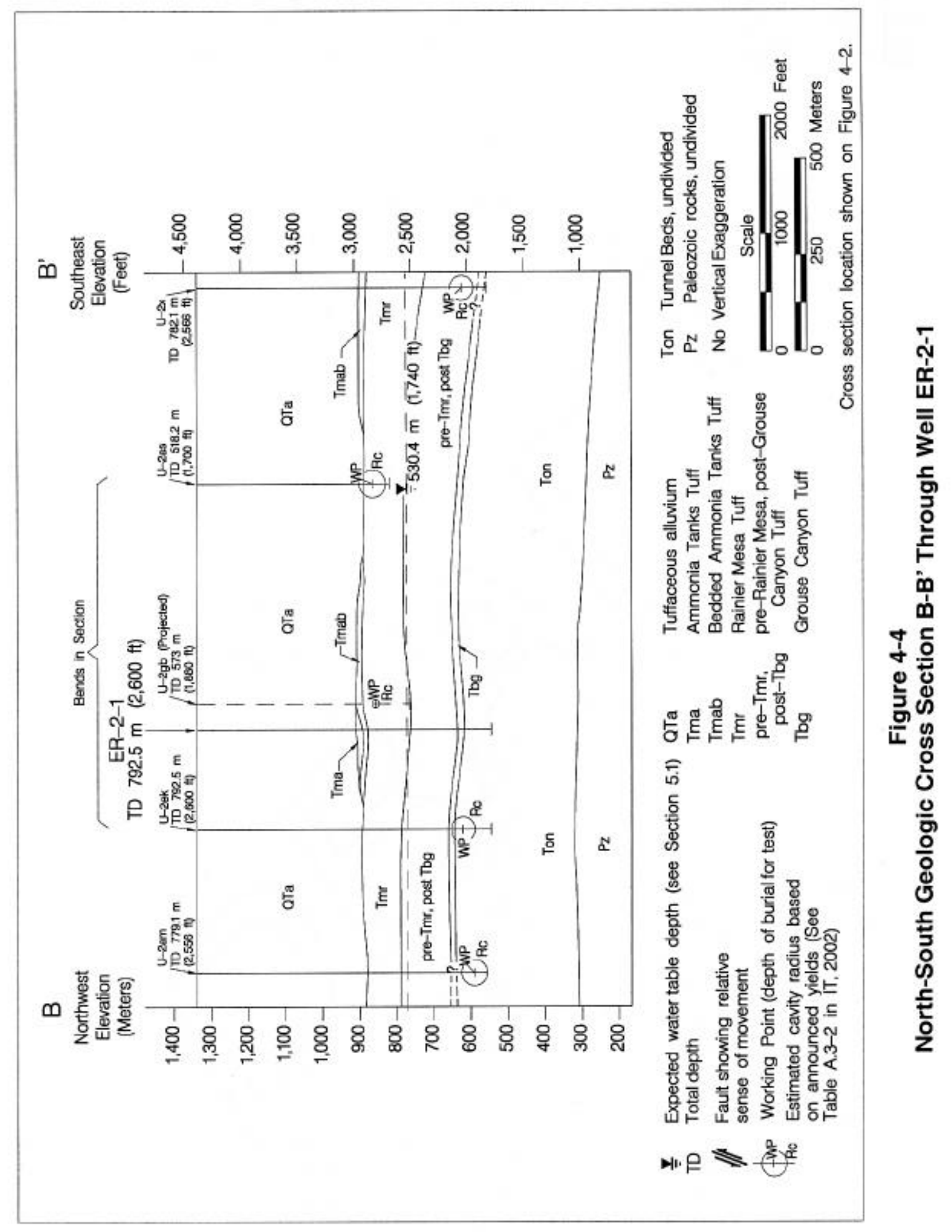


The Paleozoic surface (probably Ordovician- or Cambrian-age carbonate rocks in this area [Cole and

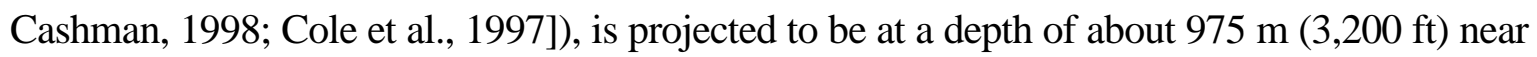
Well ER-2-1. The nearest data points for the top of the Paleozoic carbonate rocks are $440 \mathrm{~m}$ (1,440 ft) to the southeast at Instrumentation Hole U-2z \#1, where the top of the carbonate rocks was encountered at the depth of $961 \mathrm{~m}(3,153 \mathrm{ft})$, and $710 \mathrm{~m}(2,330 \mathrm{ft})$ to the west-northwest at Instrumentation Hole U2r\#1, where the carbonate rocks are $1,017 \mathrm{~m}(3,337 \mathrm{ft})$ deep.

Well ER-2-1 is located on a major west-tilted, structural block bounded on the east by the Yucca fault and on the west by the Carpetbag fault. The surface trace of the Yucca fault, is approximately $716.3 \mathrm{~m}$ $(2,350 \mathrm{ft})$ east of Well ER-2-1. One or more smaller faults sympathetic to the Yucca fault, may also be present, as shown in Figure 4-3. These faults dip steeply to the east and have stratigraphic displacement down to the east. The Well ER-2-1 borehole did not cross any discernable faults.

The Tertiary-age volcanic units in this local structural block generally dip 10 to 15 degrees toward the west, as determined from borehole data and extrapolation from structural contour maps of the area. The nearest measured bedding dip in the volcanic rocks is at Emplacement Hole U-2ek, where a dip of 13 degrees to the southwest was observed (Tewhey, 1975).

\subsubsection{Alteration}

Alteration has a significant effect on both the general hydraulic character of volcanic rocks and on how radionuclides migrate through these rocks. The predominant type of mineralogic alteration observed in each stratigraphic unit encountered in Well ER-2-1 is illustrated on Figure 4-5. Above the depth of $583.7 \mathrm{~m}(1,915 \mathrm{ft})$, the tuffs are mostly unaltered (vitric), with short intervals of silicic alteration. The top of pervasive zeolitization, which is known to cross stratigraphic boundaries, is within the Tuff of Holmes Road at Well ER-2-1. Clinoptilolite is the dominant zeolite mineral and smectite is the dominant clay. Clay content is generally less than 10 percent (WoldeGabriel et al., 2003). The abundance of secondary minerals generally increases with depth.

\subsection{Predicted versus Actual Geology}

The predicted geology for Well ER-2-1 (IT, 2002) was based on surface geologic maps by Slate et al. (1999) and Barnes et al. (1963), and the geology of nearby boreholes, including Emplacement Holes U2gb, U-2bs, U-2en, and Instrument/Exploratory Holes UE-2en-1, UE-2ek, U-2z\#1 and UE-2ar (Figure 4-2). Various reports prepared by Lawrence Livermore National Laboratory (e.g. Tewhey, 1975; Pawloski, 1985) also provided local detail. In addition, the 
This page intentionally left blank. 


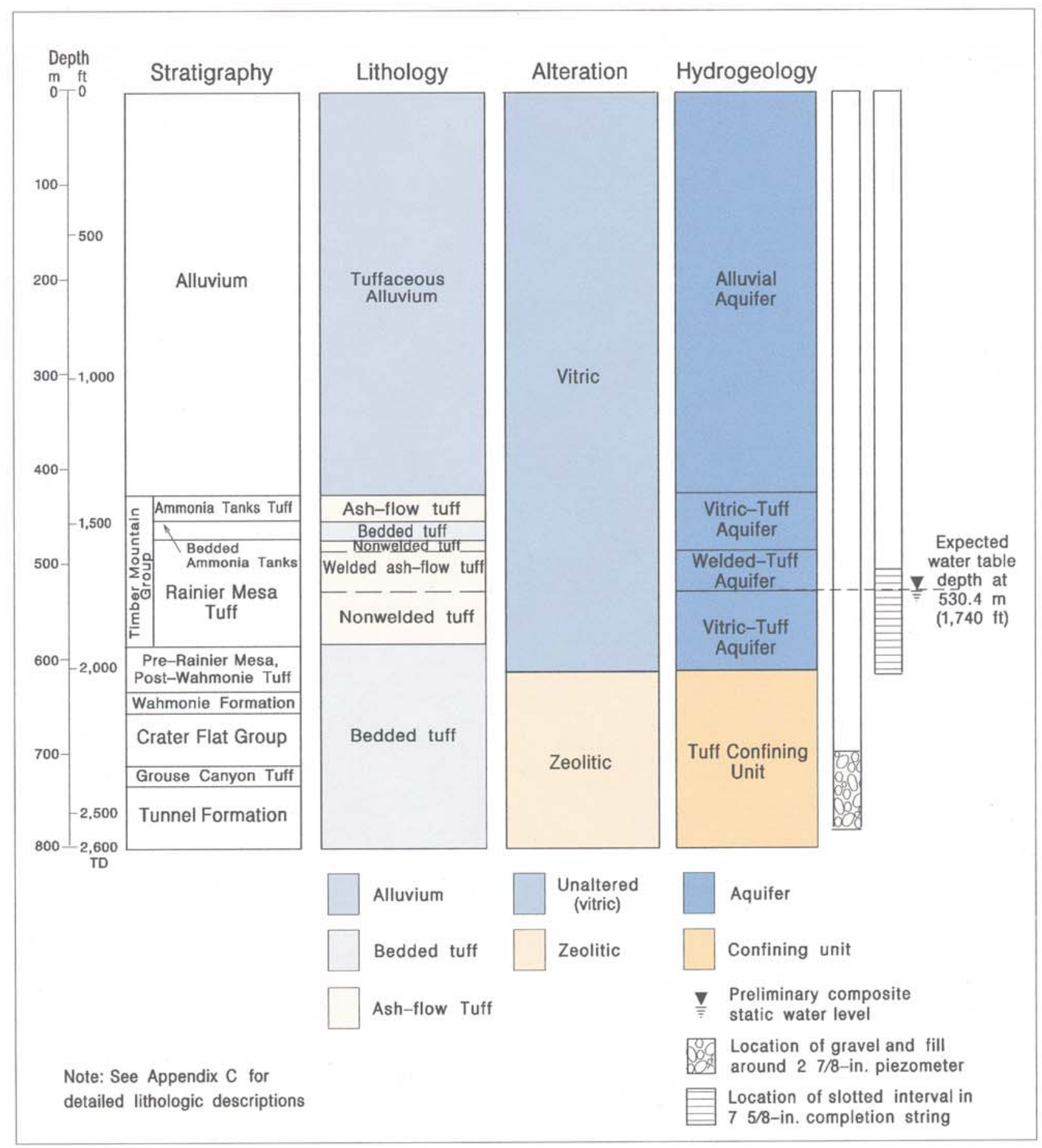

Figure 4-5

Geology and Hydrogeology of Well ER-2-1 
This page intentionally left blank. 
latest interpretation of the subsurface extent and geometry of units in Yucca Flat was incorporated from the UGTA draft Yucca Flat hydrogeologic framework model (Gonzales et al., 1998; Gonzales and Drellack, 1999).

The well was expected to penetrate approximately $420.6 \mathrm{~m}(1,380 \mathrm{ft})$ of tuffaceous alluvium overlying about $357.2 \mathrm{~m}(1,172 \mathrm{ft})$ of Tertiary-age volcanic rocks. Within the tuff section were expected $19.8 \mathrm{~m}$ (65 ft) of bedded Ammonia Tanks Tuff, 89.9 m (295 ft) of Rainier Mesa Tuff, 120.4 m (395 ft) of preRainier Mesa/post-Grouse Canyon Tuff, 39.6 m (130 ft) of Grouse Canyon Tuff, and 87.5 m (287 ft) of Tunnel Formation.

Formation tops as encountered at Well ER-2-1 tended to be slightly deeper than predicted. The borehole penetrated about $425.2 \mathrm{~m}(1,395 \mathrm{ft})$ of tuffaceous alluvium and $291.4 \mathrm{~m}$ (956 ft) of Tertiaryage tuff, which is close to the pre-drill prediction. The thin section of ash-flow tuff of the Ammonia Tanks Tuff found to be present at the top of the Tertiary-age volcanic section at Well ER-2-1 was not predicted. The top of pervasive zeolitization is $13.7 \mathrm{~m}(45 \mathrm{ft})$ deeper than expected. Such departures from pre-drill predictions for the presence or absence of the Ammonia Tanks Tuff and the exact depth of pervasive zeolitization in this portion of Yucca Flat are not unexpected. A comparison of the predicted and the actual (preliminary) stratigraphy is provided in Figure 4-6.

\subsection{Hydrogeology}

General predictions of the hydrology expected at Well ER-2-1 were based on the predicted subsurface geology (IT, 2002) and the regional hydrogeologic setting (Winograd and Thordarson, 1975; Laczniak et al, 1996). Refer to Gonzales and Drellack (1999) or IT (2002) for an overview of the hydrogeology of Yucca Flat.

The rocks in the vicinity of Well ER-2-1 can be conceptualized hydrogeologically as a framework of aquifers and confining units, as described in Section 3.0 of the Yucca Flat drilling criteria document (IT, 2002), and as shown in the right-hand column of Figure 4-5. These hydrogeologic units (HGUs) are classified into HSUs based on the hydrogeologic framework for Yucca Flat of Gonzales et al. (1998) and Gonzales and Drellack (1999), and incorporating lithologic data from nearby boreholes and outcrops. Figure 4-7 shows a cross sectional view of the HSUs in the vicinity of Well ER-2-1. The paragraphs below describe the HSUs of the Well ER-2-1 area, starting with the regional carbonate aquifer. 


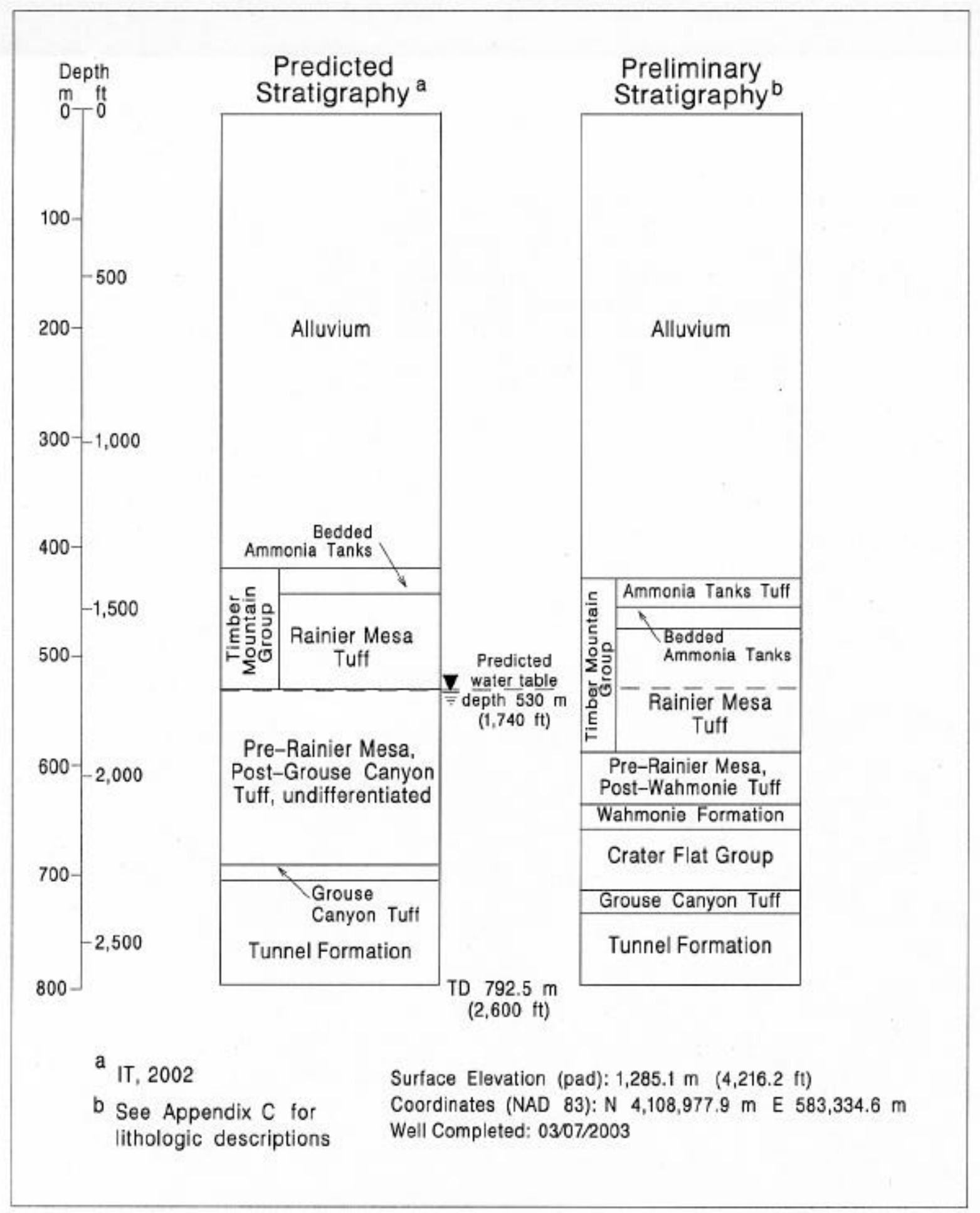

Figure 4-6

Predicted and Actual Stratigraphy at Well ER-2-1 


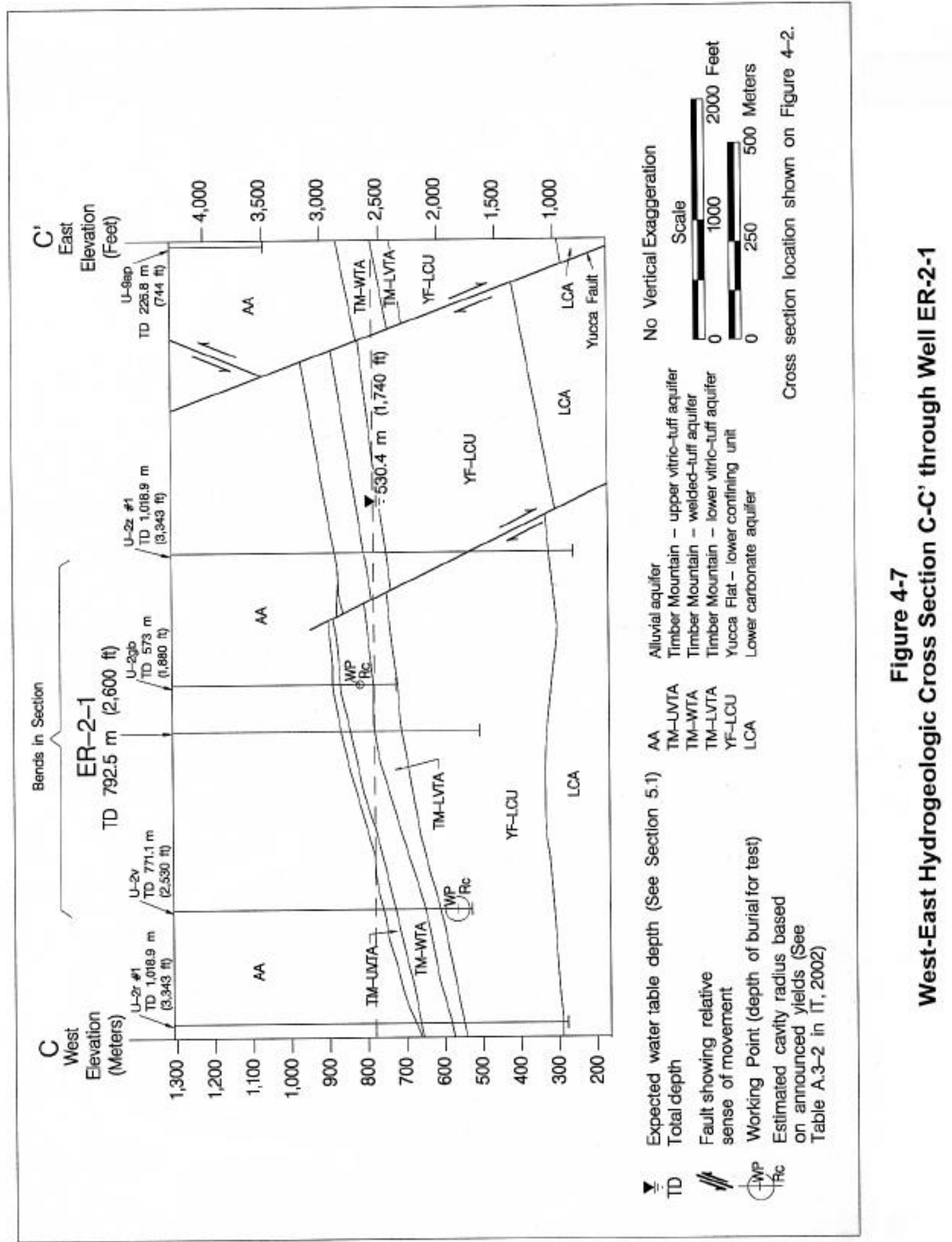


The LCA is the principle aquifer for much of southern Nevada, and consists of mostly limestone and dolomite. The LCA is projected to be at a depth of $975 \mathrm{~m}(3,200 \mathrm{ft})$, or $183 \mathrm{~m}(600 \mathrm{ft})$ below the TD of Well ER-2-1 (see Figure 4-4).

The top of zeolitic, bedded air-fall, and nonwelded ash-flow tuffs of the YF-LCU is at the depth of

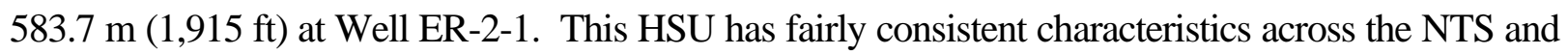
typically yields very little water. However, rare fractures could transport some quantity of groundwater.

The Timber Mountain volcanic aquifers in Yucca Flat consist of vitric to devitrified, nonwelded to densely welded ash-flow tuffs of the Ammonia Tanks and Rainier Mesa Formations. These units are divided into three HSUs:

- Timber Mountain upper vitric tuff aquifer (TM-UVTA)

- Timber Mountain welded tuff aquifer (TM-WTA)

- Timber Mountain lower vitric tuff aquifer (TM-LVTA).

At Well ER-2-1 the TM-UVTA consists of nonwelded ash-flow tuff and bedded tuff in the interval 425.2 to $470.0 \mathrm{~m}$ (1,395 to 1,542 ft), just below the alluvium. The underlying TM-WTA is present in the depth interval 470.0 to $530.4 \mathrm{~m}$ (1,542 to 1,740 ft). The TM-LVTA consists of the unaltered tuffs between the TM-WTA and the top of pervasively zeolitized tuffs (tuff confining units). The TM-LVTA was the aquifer of interest at Well ER-2-1 and was encountered between 530.4 and $583.7 \mathrm{~m}$ (1,740 and 1,915 ft) depth. The Well ER-2-1 area is one of the few locales in Yucca Flat where underground nuclear tests were conducted within or near a saturated volcanic aquifer.

The alluvial aquifer in southern Yucca Flat is a gravelly, sandy, tuffaceous alluvium that is unsaturated in the vicinity of Well ER-2-1.

Hydraulic properties of volcanic units in the Yucca Flat area can vary greatly based on physical characteristics that affect fractures and secondary alteration. See Subsection 3.4.1 and Table 3-5 in the drilling criteria document (IT, 2002) for additional information on the characteristics of Yucca Flat HGUs. In general, the most transmissive volcanic units at the NTS are lava flows (lava-flow aquifer) and moderately to densely welded ash-flow tuffs (welded-tuff aquifer). Nonwelded to partially welded, unaltered ash-flow tuffs and some less fractured lava flows have intermediate hydraulic conductivities. Nonwelded ash-flow tuffs and bedded tuffs (ash-fall tuffs and reworked tuffs) usually are characterized by moderate to low hydraulic conductivity (vitric-tuff aquifer). Secondary alteration of these tuffs (most 
commonly zeolitization) makes tuffs less permeable, and altered tuffs typically are regarded as confining units.

The highest saturated HSU in Well ER-2-1 is the TM-LVTA, a vitric-tuff aquifer (Figure 4-7]). At Well ER-2-1 the entire 53.3-m (175-ft) thickness of this HSU is saturated.

Hydraulic properties of the HGUs expected at Well ER-2-1 were provided in Table A.6-1 of IT (2002). Estimates of transmissivity and potential specific capacity were based on hydraulic conductivity ranges given for the referenced hydrogeologic units in DOE/NV (1997) and the estimated unit thickness given in Table A.5-1 of IT (2002). Enhanced formation conductivity due to test-related fractures was also postulated for this location. See the discussion of the general hydraulic properties of the hydrogeologic units, expected in Well ER-2-1 in IT (2002), Section A.6.2.

Low water production during drilling at Well ER-2-1 is an initial indicator that hydraulic conductivities here are low to very low, but not outside the typical range for Yucca Flat HSUs. A preliminary evaluation suggests that enhanced formation conductivity due to test-related fractures is not a significant factor at the Well ER-2-1 location. Planned hydrologic testing in the Well ER-2-1 may have to be modified to accommodate the low hydraulic conductivity of the rocks penetrated. 
This page intentionally left blank. 


\subsection{Hydrology}

\subsection{Preliminary Water-Level Information}

The elevation of the water table at Well ER-2-1 was projected to be approximately $756.5 \mathrm{~m}(2,482 \mathrm{ft})$, as derived from sparse hydrologic data for this region (IT, 1996; Hale et al., 1995). Based on the preconstruction estimate of surface elevation at the site, depth to the water table was expected to be approximately $530.4 \mathrm{~m}$ (1,740 ft) (IT, 2002). A fluid level depth of $673.6 \mathrm{~m}$ (2,210 ft) was measured during geophysical logging of the borehole immediately after TD was reached. A composite, open-hole fluid level was measured at the depth of $534.8 \mathrm{~m}$ (1,754.6 ft) on March 4, 2003, before the completion strings were installed (Shaw, 2003). These measurements indicate a rise in fluid level of approximately $138.8 \mathrm{~m}(455.5 \mathrm{ft})$ in the two days after the hole reached TD.

Planned post-completion measurements of the fluid level in the piezometer string set in the YF-LCU (see Section 7.0 of this report) may indicate whether the hypothesized "over-pressurized zone" exists in this part of Yucca Flat. The over-pressure is a consequence of underground testing and is maintained by the low conductivity of the zeolitic bedded tuffs (Hawkins et al., 1987; Wohletz and Hawkins, 1998). A similar situation exists in the Tuff Pile area of western Area 7 (Hawkins et al., 1987).

\subsection{Water Production}

Water production was estimated during drilling of Well ER-2-1 on the basis of LiBr dilution data as measured by Shaw field personnel (Shaw, 2003). The water production rate at Well ER-2-1 remained relatively low during drilling. The primary water-producing unit(s) at this location are the unaltered, nonwelded to partially welded Rainier Mesa Tuff and the upper-most portion of the underlying preRainier Mesa vitric bedded tuffs. Measurable water production (approximately 7.6 to $56.8 \mathrm{lpm}$ [2 to $15 \mathrm{gpm}])$ was first noted at the depth of about $554.1 \mathrm{~m}(1,818 \mathrm{ft})$ within the TM-LVTA. Water production during drilling of the underlying zeolitic tuffs (YF-LCU) was also generally low, at less than about 7.6 to $37.9 \mathrm{lpm}$ (2 to $10 \mathrm{gpm}$ ). Zeolitic tuffs at the NTS typically exhibit very low hydraulic conductivities and perched water above or within them is not uncommon. Water production rates during drilling are presented graphically in Appendix A-1. 


\subsection{Preliminary Flow Meter Data}

Flow meter data, along with temperature, electrical conductivity (EC), and $\mathrm{pH}$ measurements, can be used to characterize borehole fluid variability, which may indicate inflow and outflow zones. The design of the completion string for Well ER-2-1 was based in part on field evaluation of data from these measurements.

DRI personnel made measurements with their thermal flow meter (TFM) tool at six locations between the depths of 579.1 and $672.1 \mathrm{~m}$ (1,900 and 2,205 ft) before the completion string and piezometer tube were installed. Preliminary analysis of a plot of the discrete TFM data points indicates a downward flow (less than $3.1 \mathrm{lpm}$ [0.8 gpm]) of water above the depth of $630.9 \mathrm{~m}$ (2,070 ft), and upward flow (less than $0.87 \mathrm{lpm}[0.2 \mathrm{gpm}])$ at the three deeper stations within the borehole.

In addition, DRI ran a chemistry log, which included measurements of temperature, $\mathrm{EC}$, and $\mathrm{pH}$, from top of fill at $716.9 \mathrm{~m}(2,352 \mathrm{ft})$ to $535.2 \mathrm{~m}(1,756 \mathrm{ft})$. Groundwater temperature gradually increased from the minimum reading of 23.0 degrees Celsius $(\mathrm{C})(73.5$ degrees Fahrenheit $[\mathrm{F}])$ at the top of the fluid column at $534.9 \mathrm{~m}(1,755 \mathrm{ft})$ to 25.9 degrees $\mathrm{C}$ (78.6 degrees $\mathrm{F})$ at the lowest measurement depth of approximately $716.9 \mathrm{~m}(2,352 \mathrm{ft})$. The shape of the temperature log generally reflects downward flow to the depth of $632.5 \mathrm{~m}$ (2,075 ft), corresponding to the flow log data.

Plots of the TFM and chemistry log data are reproduced in Appendix D.

\subsection{Preliminary Groundwater Characterization Samples}

Following geophysical logging, DRI collected preliminary groundwater characterization samples within the open borehole. Two discrete 6-liter (1.6-gallon) samples were collected on March 4, 2003, at the depths of 609.5 and $640.1 \mathrm{~m}$ (2,000 and 2,100 ft). Analytical data from these initial samples collected before formal well development, will provide a basis for comparison with future groundwater chemistry data. 


\subsection{Precompletion and Open-Hole Development}

The only pre-completion development conducted in Well ER-2-1 consisted of circulating air for

30 minutes to clean and initiate development the borehole. This process was conducted immediately after TD was reached and prior to geophysical logging. 
This page intentionally left blank.

6-2 


\subsection{Well Completion}

\subsection{Introduction}

Well completion refers to the installation in a borehole of one or more strings of pipe (tubing or casing) that is slotted or screened at one or more locations along its length. The completion process also typically includes emplacement of backfill materials around the pipe, with coarse fill such as gravel adjacent to the open intervals and impervious materials such as cement between or above the open intervals to isolate them. The pipe serves as a conduit for insertion of a pump in the well, for inserting devices for measuring fluid level, and/or for sampling, so that accurate potentiometric and water chemistry data can be collected from known portions of the borehole.

The well completion design as proposed in the Yucca Flat Drilling Criteria (IT, 2002) is presented in Section 7.2.1. A description of the actual well completion, based on hole conditions and the hydrogeology encountered, is presented in Section 7.2.2.

Completion activities at Well ER-2-1 took place March 5 to 7, 2003. A pump will be installed later as needed for hydrologic testing. Figure 7-1 is a schematic of the final well completion design for Well ER2-1, Figure 7-2 shows a plan view and profile of the wellhead surface completion, and Table 7-1 is a construction summary for the well. Data for this section were obtained from daily operations and activity reports, casing records, and cementing records provided by the BN Drilling Department. Information from Shaw's well data report (Shaw, 2003) was also consulted for preparation of this section.

\subsection{Well Completion Design}

The final completion design differs slightly from the proposed design, as described in the following paragraphs.

\subsubsection{Proposed Completion Design}

Well ER-2-1 was designed to provide information and groundwater production from intervals within the TM-LVTA and the YF-LCU in an area thought to be affected by underground nuclear tests. The original completion design (IT, 2002) was based on the assumption that Well ER-2-1 would penetrate a significant thickness of saturated, unaltered, nonwelded and bedded tuffs (vitric-tuff aquifer) above the YF-LCU. This vitric tuff aquifer was the primary target for Well ER-2-1. The planned completion design also included one or two completion intervals within the YF-LCU depending upon hydraulic conductivity conditions and radionuclides 


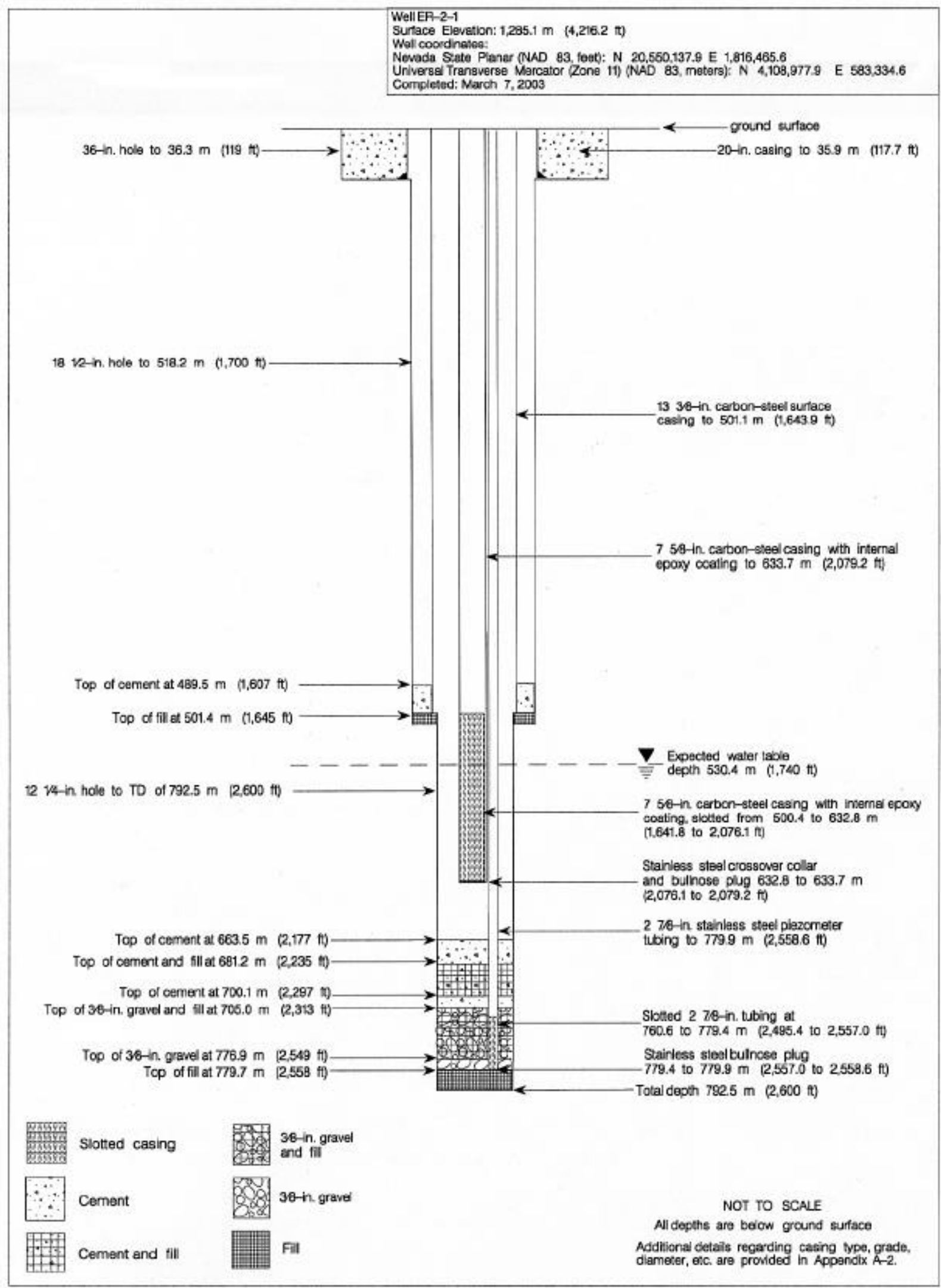

Figure 7-1

As-Built Completion Schematic for Well ER-2-1 


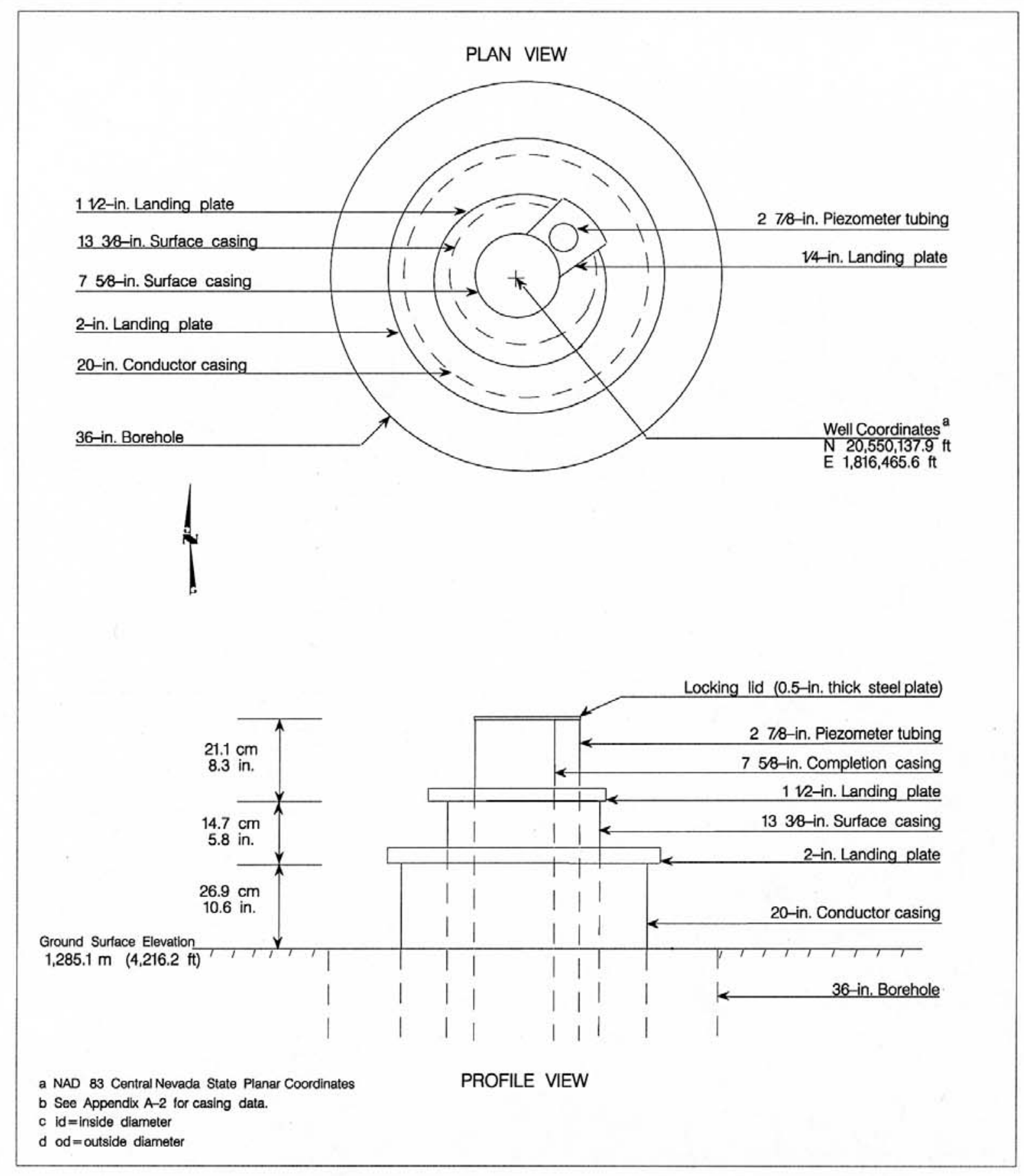

Figure 7-2

Wellhead Diagram for Well ER-2-1 
Table 7-1

Construction Summary for Well ER-2-1 Completion Strings

\begin{tabular}{|c|c|c|c|c|}
\hline Casing/Tubing & \multicolumn{2}{|c|}{$\begin{array}{c}\text { Configuration } \\
\text { meters (feet) }\end{array}$} & Cement & Sand/Gravel \\
\hline \multirow{3}{*}{$\begin{array}{l}\text { 7e -in. carbon- } \\
\text { steel production } \\
\text { casing with } \\
\text { internal epoxy } \\
\text { coating }\end{array}$} & $\begin{array}{c}0 \text { to } 500.4 \\
(0 \text { to } 1,641.8)\end{array}$ & $\begin{array}{c}\text { Blank } \\
0 \text { to } 500.4 \\
(0 \text { to } 1,641.8)\end{array}$ & \multirow{3}{*}{ None } & \multirow{3}{*}{ None } \\
\hline & $\begin{array}{c}500.4 \text { to } 632.8 \\
(1,641.8 \text { to } 2,076.1)\end{array}$ & $\begin{array}{l}14 \text { consecutive } \\
\text { slotted joints }\end{array}$ & & \\
\hline & $\begin{array}{c}632.8 \text { to } 633.7 \\
(2,076.1 \text { to } 2,079.2\end{array}$ & $\begin{array}{l}\text { Blank and } \\
\text { bull-nosed }\end{array}$ & & \\
\hline \multirow{3}{*}{$\begin{array}{c}2 f \text {-in. } \\
\text { Stainless-steel } \\
\text { piezometer tubing }\end{array}$} & $\begin{array}{c}0 \text { to } 760.6 \\
0 \text { to } 2,495.4\end{array}$ & Blank & \multirow{3}{*}{$\begin{array}{c}\frac{\text { Type II Neat }}{\text { Cement }} \\
663.5 \text { to } 681.2 \\
(2,177 \text { to } 2,235) \\
\frac{\text { Cement and fill a }}{681.2 \text { to } 700.1} \\
(2,235 \text { to } 2,297) \\
\frac{\text { Type II Neat }}{\text { Cement }} \\
700.1 \text { to } 705.0 \\
(2,297 \text { to } 2,313)\end{array}$} & \multirow{2}{*}{$\begin{array}{c}\frac{3 / 8 \text {-inch } \times 4 \text { Gravel }}{\text { and Fill }^{\text {a }}} \\
705.0 \text { to } 776.9 \\
(2,313 \text { to } 2,549) \\
\frac{3 / 8 \text {-inch } \times 4 \text { Gravel }}{776.9 \text { to } 779.7} \\
(2,549 \text { to } 2,558)\end{array}$} \\
\hline & $\begin{array}{c}760.6 \text { to } 779.4 \\
(2,495.4 \text { to } 2,557.0)\end{array}$ & $\begin{array}{l}2 \text { consecutive } \\
\text { slotted joints }\end{array}$ & & \\
\hline & $\begin{array}{c}779.4 \text { to } 779.9 \\
2,557.0 \text { to } 2,558.6\end{array}$ & $\begin{array}{l}\text { Blank and } \\
\text { bull-nosed }\end{array}$ & & $\begin{array}{c}\text { Fill } \\
779.7 \text { to TD } \\
(2,558 \text { to } 2,600)\end{array}$ \\
\hline
\end{tabular}

a Hole sloughed during emplacement of gravel and cement, causing mixing of natural material with cement and gravel.

encountered during drilling. Tentative completion intervals were selected to correspond to working point depths of nearby underground tests (e.g., U-2ek and U-2en; refer to Figure A.6-1 in IT [2002]).

The well was planned to be completed with a single string consisting of 51/2-in. stainless-steel casing suspended on $7 e$-in. epoxy-coated carbon-steel casing. The 51/2-in. casing would permit access one or two horizons in the YF-LCU through slotted and gravel-packed intervals isolated by cement. The 7e in. casing would provide access to the TM-LVTA through a single slotted interval. 


\subsubsection{As-Built Completion Design}

The design of the Well ER-2-1 completion was determined through consultation with members of the UGTA TWG, on the basis of onsite evaluation of data such as lithology and water production, drilling data, data from various geophysical logs, and data from flow meter and water chemistry logs. The asbuilt completion design for Well ER-2-1 provides access to the TM-LVTA (a semi-perched water zone) via the larger $7 e$-in. production casing, and to the YF-LCU via a relatively small diameter piezometer tube (Figure 7-1). The compositions of the strings summarized here are detailed on Table 7-1, and the casing materials are listed in Appendix A-2.

The $7 \mathrm{e}$-in. production casing is slotted in the interval 500.4 to $632.8 \mathrm{~m}(1,641.8$ to $2,076.1 \mathrm{ft})$ and consists of 14 consecutive slotted joints. No gravel-pack or cement was needed because the open interval is isolated from the underlying units by cement. The openings in each slotted casing joint are $0.15 \mathrm{~cm}(0.0625 \mathrm{in}$.) wide and $5.1 \mathrm{~cm}$ ( 2 in.) long, cut in rings of 18 slots (spaced 20 degrees apart around the joint). The rings are spaced on 15.2-cm (6-in.) centers and the longitudinal centers of the slots in each ring are offset 10 degrees from the slot centers in the next ring. No slots are cut within $0.6 \mathrm{~m}(2 \mathrm{ft})$ of the ends of the slotted joints to assure that the strength of the pipe near the connections is not degraded.

The $2 f$-in. stainless-steel piezometer tube accesses the YF-LCU through slotted joints in the interval 760.6 to $779.4 \mathrm{~m}(2,495.4$ to $2,557.0 \mathrm{ft})$, just above fill, which was tagged at $779.7 \mathrm{~m}(2,558 \mathrm{ft})$ prior to setting the piezometer string. A stainless-steel, bullnose plug is installed at the bottom of the $2 f$-in. tubing, and the slotted interval is gravel-packed and isolated with cement. The openings in each slotted tubing joint are nominally $0.20 \mathrm{~cm}$ (0.079 in.) wide and $5.1 \mathrm{~cm}$ (2 in.) long, cut in rings of 8 slots, spaced 45 degrees apart around the joint. The rings are spaced on 15.2-cm (6-in.) centers and the longitudinal centers of the slots in each ring are offset 22.5 degrees from the next ring. No slots are cut within $0.5 \mathrm{~m}$ $(1.5 \mathrm{ft})$ of the ends of the slotted joints to assure that the strength of the pipe near the connections is not degraded.

\subsubsection{Rationale for Differences between Planned and Actual Well Design}

The initial planned well design was based on an expected geologic setting in which groundwater, possibly contaminated with radionuclides from nearby underground nuclear tests, would be present in the TMLVTA, and that the YF-LCU would be relatively conductive due to fracturing as a result of the nearby tests. Based on these pre-drill expectations, the planned well design included the construction of one completion zone in the TM-LVTA and placement of one or two slotted intervals within the YF-LCU at depths approximately equal to those of nearby underground nuclear tests. 
The geology encountered at Well ER-2-1 was as expected. However, the zeolitic units did not yield as much water as expected if conductivity had been enhanced by fracturing due to nearby underground tests. The TM-LVTA also seems not to be very conductive.

The planned completion design as presented in IT (2002) was modified to accommodate the low conductivity conditions encountered in Well ER-2-1 and to contend with accumulating fill at the bottom of the borehole. Low hydraulic conductivity may also preclude the certain aspects of the planned pumping tests and other objectives. Obtaining water-level measurements and samples for water chemistry at Well ER-2-1 are important scientific objectives of Well ER-2-1. These data can be collected either through the larger $7 e$-in. completing casing or though the $2 f$-in. piezometer tube which accesses the YF-LCU.

\subsection{Well Completion Method}

Well completion activities began at Well ER-2-1 on March 5, 2003. The UDI crew ran a $2 f$-in. tremie line to $782.1 \mathrm{~m}(2,566 \mathrm{ft})$, and tagged fill at $782.1 \mathrm{~m}(2,566 \mathrm{ft})$. Next, the drill crew landed the $2 \mathrm{f}$-in. stainless-steel piezometer at $779.9 \mathrm{~m}(2,558.6 \mathrm{ft})$. The piezometer string was gravel-packed from the top of fill to $705.0 \mathrm{~m}$ (2,313 ft) using 4,921.6 kilograms (10,850 pounds) of gravel, in two lifts. The borehole sloughed during pouring of the gravel, so that a mixture of natural sloughed material and gravel is present in the interval 705.0 to $776.9 \mathrm{~m}$ (2,313 to 2,549 ft). The slotted and gravel-packed interval is isolated with 6.4 cubic meters ( 225 cubic feet) of Type II neat cement placed in two stages. The borehole sloughed again during the first cementing operation, resulting in a cement-fill mixture in the depth interval 681.2 to $700.1 \mathrm{~m}$ (2,235 to $2,297 \mathrm{ft})$. The casing crew landed the $7 \mathrm{e}$-in. production casing at $633.7 \mathrm{~m}$ (2079.2 ft) on March 7, 2003. No gravel pack or cement was used with this casing string (Figure 7-1).

All well construction materials were inspected according to relevant procedures, and standard decontamination procedures were employed to prevent the introduction of contaminants into the well.

Because a pump was not installed in the well, no well-development or pumping tests were conducted immediately after completion. 


\subsection{Actual versus Planned Costs and Scheduling}

The BN cost model developed for Well ER-2-1 was based on the plan to drill to a TD of $792.5 \mathrm{~m}$ $(2,600 \mathrm{ft})$. The drilling program baseline projected that it would require 25 days to accomplish drilling of the surface and main holes, and logging and completion for the well, assuming the conductor hole would already have been constructed by BN. The actual time spent to drill the main and surface holes at Well ER-2-1 was 14 days. Drilling of the 47.0-cm (18.5-in.) and 31.1-cm (12.25-in.) borehole was accomplished more quickly than expected. Geophysical logging operations proceeded as expected. Installation of the $2 f$-in. piezometer and the $7 e$-in. casing also took less time than predicted. A graphical comparison, by day, of planned and actual well construction activities is presented in Figure 8-1.

The cost analysis for Well ER-2-1 begins with the movement of the UDI drill rig to the Well ER-2-1 site from the site of Well ER-7-1. The cost of building roads, the drill pad, and sumps is not included, and the cost of well-site support by Shaw is not included. The total construction cost for Well ER-2-1 includes all drilling costs: charges by the drilling subcontractor; charges by other support subcontractors (including compressor services, drilling fluids, bits, casing services, down-hole tools, and geophysical logging); and charges by $\mathrm{BN}$ for mobilization and demobilization of equipment, construction of the conductor hole, cementing services, completion materials, radiation technicians, inspection services, and geotechnical consultation.

The total planned cost for constructing Well ER-2-1 was $\$ 2,168,546$. The actual cost was $\$ 1,685,997$, or 22.3 percent less than the planned cost, which reflects the fact that the well was drilled and completed in significantly less time than planned. Figure 8-2 presents a comparison of the planned (baseline task plan) and actual costs, by day, for drilling and completing Well ER-2-1. 


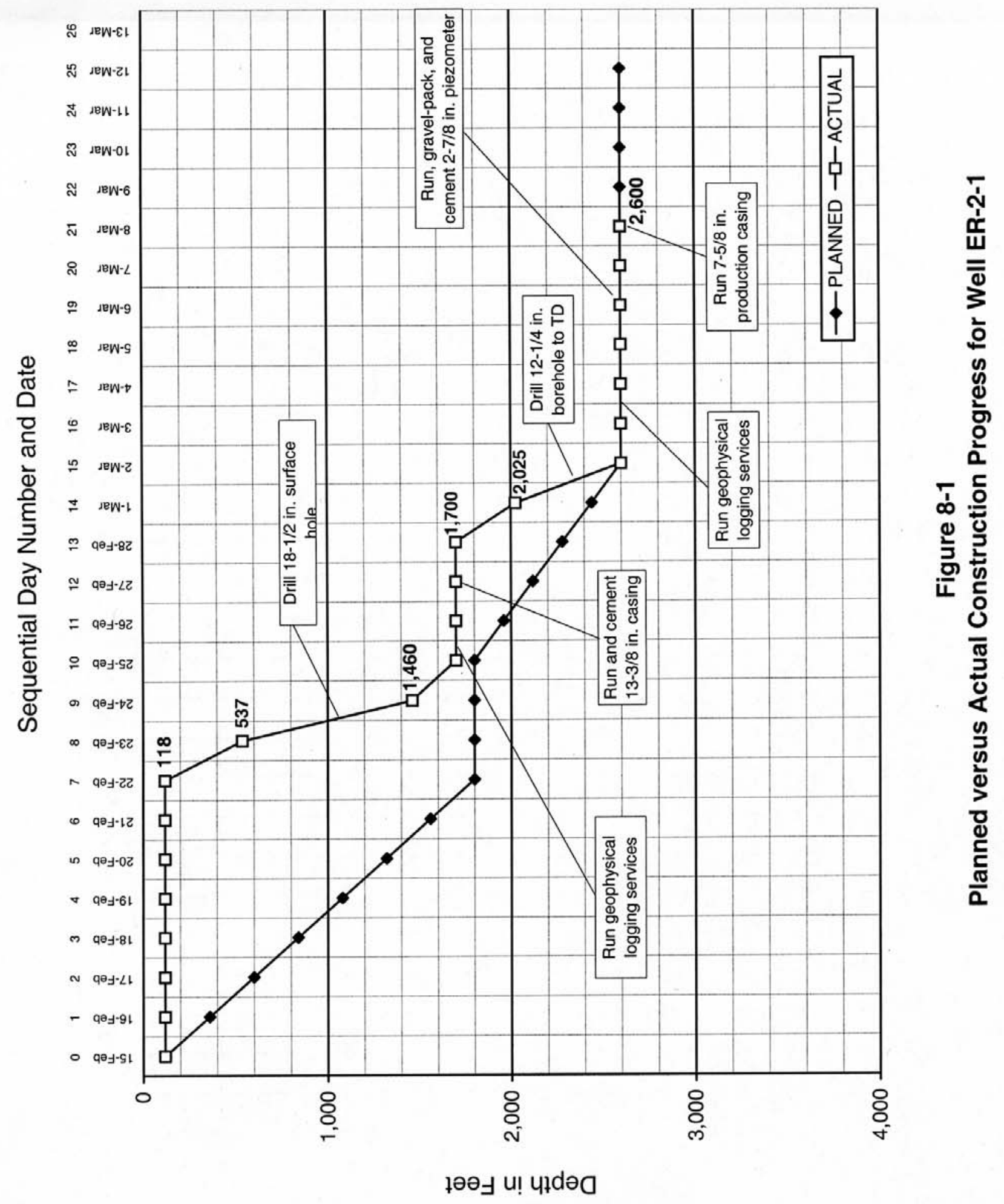




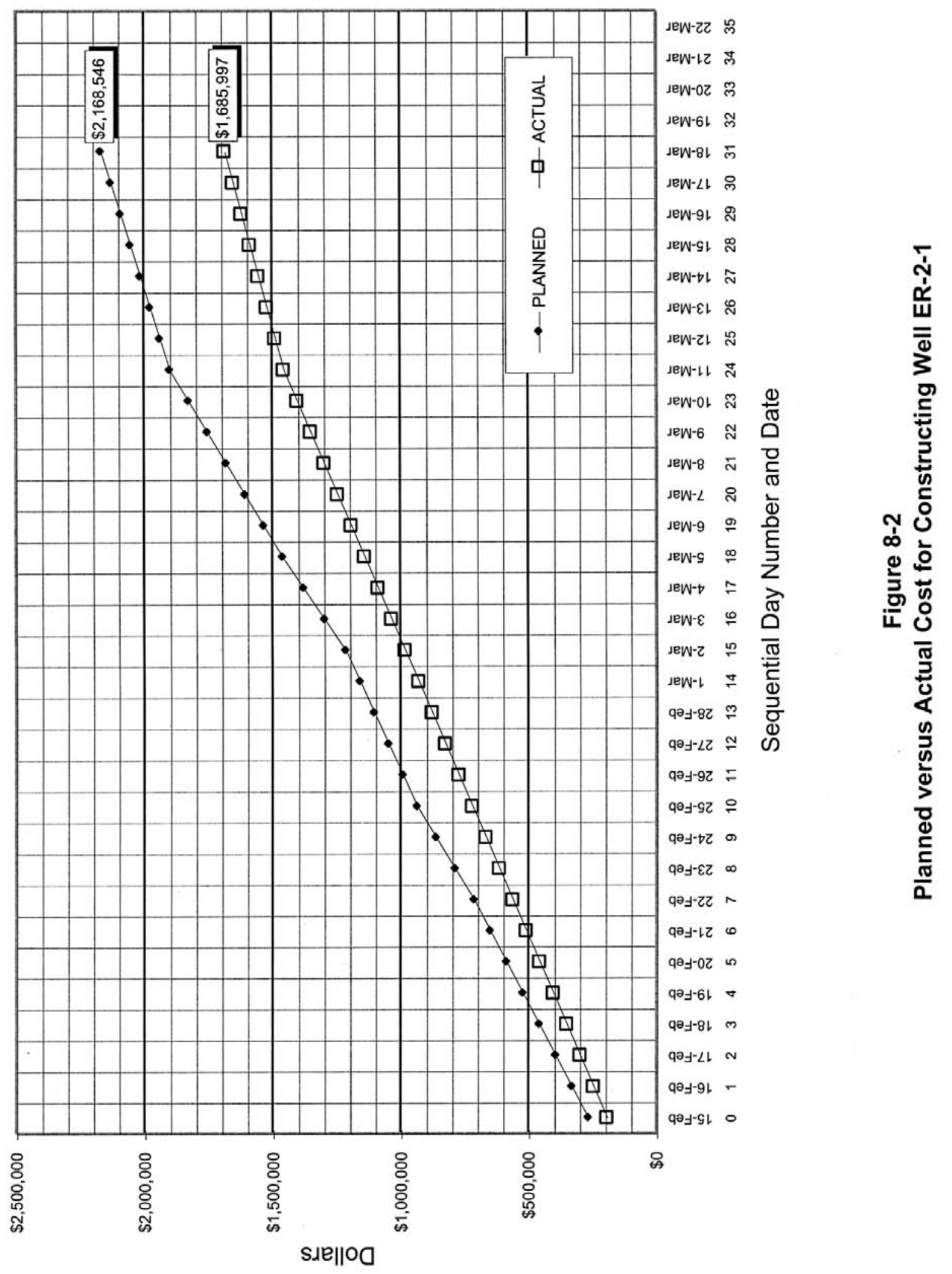


This page intentionally left blank.

8-4 


\subsection{Summary, Recommendations, and Lessons Learned}

\subsection{Summary}

Subcontractor activities at Well ER-2-1 commenced on February 12, 2003, and concluded on March 10, 2003, when the UDI rig was released and crews began demobilizing and moving equipment offsite. The TD of $792.5 \mathrm{~m}$ (2,600 ft) was reached on March 2, 2003. Crews worked on a 7-daysper-week, 24-hours-per-day schedule for most of the operation. Fourteen working days were expended to drill the surface and main holes, conduct geophysical logging, and install the completion casing and piezometer tubing.

Composite drill cuttings were collected every $3.05 \mathrm{~m}$ (10 ft) from $36.6 \mathrm{~m}$ (120 ft) to TD. Eighty-three percussion-gun sidewall core samples were collected in the interval 113.7 to $754.4 \mathrm{~m}$ (373 to 2,475 ft). Geophysical logging was conducted in the upper part of the borehole before installation of the surface casing, and in the lower portion of the hole before installation of the completion strings. Some of these logs were used to aid in construction of the well, while others helped to verify the geology and determine the hydrologic characteristics of the rocks.

Well ER-2-1 is collared in alluvium, which is $425.2 \mathrm{~m}$ (1,395 ft) thick, and reached TD in zeolitic Tertiary tuffs. Nonwelded to densely welded ash-flow tuffs of the Ammonia Tanks and Rainier Mesa

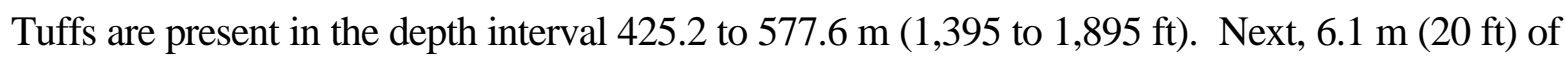
unaltered, bedded tuffs related to the Tuff of Holmes Road were penetrated. And finally, $208.8 \mathrm{~m}$ (685 $\mathrm{ft}$ ) of zeolitic bedded tuffs related to the Paintbrush, Calico Hills, and Wahmonie Formations, Crater Flat Group, Grouse Canyon Formation, and 4 Member of the Tunnel Formation were drilled. Confidence in the pre-Rainier Mesa Tuff stratigraphy is provided by two marker beds, the mafic-rich Wahmonie Tuff and the peralkaline Grouse Canyon Tuff air-fall tuff.

Tritium was noted during drilling in the vadose zone at 328.0 to $490.7 \mathrm{~m}(1,076$ to $1,610 \mathrm{ft})$ and again in the saturated section at 743.7 to $765.0 \mathrm{~m}$ (2,440 to 2,510 ft) depth. Activity levels were less than $8,700 \mathrm{pCi} / \mathrm{L}$ in these two intervals, and returned to background levels elsewhere. No other radionuclides above background have been identified to date in groundwater produced from Well ER-2-1. All fluids produced during the construction of Well ER-2-1 were contained in the two lined sumps.

The borehole was completed with a 7e -in. carbon-steel casing with internal epoxy coating, set at 633.7 $\mathrm{m}(2,079.3 \mathrm{ft})$, and accessing the TM-LVTA through slots at 500.4 to $632.8 \mathrm{~m}(1,641.8$ to 2,076.1 $\mathrm{ft})$. 
A $2 f$-in. stainless-steel piezometer tube was also installed that accesses the underlying YF-LCU through slots at 760.6 to $779.4 \mathrm{~m}$ (2,495.4 to 2,557.0 ft). The piezometer string is gravel-packed and isolated with cement. The 7e -in. production casing is not gravel packed.

A pre-completion fluid-level depth of $534.8 \mathrm{~m}$ (1,754.6 ft) was measured in the open borehole on March 4, 2003. The fluid level in the borehole had risen approximately $138.8 \mathrm{~m}$ (455.5 ft) in the two days after drilling was completed. This may indicate the presence of the hypothesized "over-pressurized zone," a consequence of underground testing maintained by the low conductivity of zeolitic bedded tuffs. Planned hydrologic testing will provide more information on this possibility.

\subsection{Recommendations}

Because of the low conductivity formations encountered at Well ER-2-1 it may not be possible to accomplish the planned pumping and hydrologic testing. The plan for the pumping tests may need to be revised to address the low conductivity formations. The well may need to be pumped for a longer duration to capture radioactive or otherwise contaminated groundwater from any nearby plume.

The piezometer tubing was landed on fill, and there is concern that the slots might be silted in. The piezometer tubing should be cleaned of sediment to ensure that valid water-level measurements can be made.

Water samples should be collected from the piezometer tube for chemistry analysis after the tubing string is cleaned out. The analyses should include the full suite including radiological and environmental isotopes.

\subsection{Lessons Learned}

The efficiency of drilling and constructing wells to obtain hydrogeologic data in support of the UGTA Project continues to improve as experience is gained with each new well. Sometimes difficult drilling conditions are encountered and challenges are confronted. Several new lessons were learned during the construction of Well ER-2-1, the last well in the 2003 Yucca Flat drilling initiative.

- Useful hydrologic information can be acquired at well locations where rocks of very low hydraulic conductivity are encountered.

- During the second geophysical logging operation (hole at TD) the percussion-gun coring tool malfunctioned. Time was lost each of the three times the tool was run into the borehole, failed, 
and then had to be retrieved. Less than diligent trouble-shooting procedures failed to identify the problem, which was later found to be a leak in the wireline.

- A drilling subcontractor employee was injured and another was exposed to a near-miss incident during mobilization and rigging-up activities. Continuing to address worker safety, recognition of workplace hazards, and implementation of mitigation controls during on-site daily safety meetings is imperative.

- The plastic-lined walkways and work areas required to address radiological issues created physical hazards for workers. The consequences of the implementation of radiological (or other) controls must be considered to avoid creating additional hazards for workers. 
This page intentionally left blank.

$9-4$ 


\subsection{References}

Bangerter, R. M., National Nuclear Security Administration Nevada Site Office. 2003. Verbal communication to P. K. Ortego, Bechtel Nevada. Subject: Lining of Sumps at the ER-2-1 Site. BN Record of Verbal Communication Number RVC-03-0003. February 3, 2003.

Barnes, H., F. N. Houser, and F. G. Pool. 1963. Geologic Map of the Oak Spring Quadrangle, Nye County, Nevada. U.S. Geological Survey Geologic Quadrangle Map 214, scale 1:24,000. Washington, DC.

Bechtel Nevada. 2001a. Underground Testing Area (UGTA) Project Health and Safety Plan, January, 2001. Las Vegas, NV.

Bechtel Nevada. 2001b. Nevada Test Site Annual Site Environmental Report for Calendar Year 2001. DOE/NV11718-747. Las Vegas, NV.

Bechtel Nevada. 2003. Field Activity Work Plan for Main-Hole Drilling and Completion of Underground Test Area (UGTA) Investigation Well ER-2-1. Field Activity Work Plan Number D-002-001.03. Las Vegas, NV.

BN, see Bechtel Nevada.

Byers, F. M., Jr., W. J. Carr, P. P. Orkild, W. D. Quinlivan, and K. A. Sargent. 1976. Volcanic Suites and Related Cauldrons of the Timber Mountain-Oasis Valley Caldera Complex, Southern Nevada. U.S. Geological Survey Professional Paper 919.

Cole, J. C., and P. H. Cashman. 1998. Structural Relationships of Pre-Tertiary Rocks in the Nevada Test Site Region, Southern Nevada. U.S. Geological Survey Professional Paper 1607.

Cole, J. C., A. G. Harris, and R. R, Wahl. 1997. "Subcrop Geologic Map of Pre-Tertiary Rocks in the Yucca Flat and Northern Frenchman Flat Areas, Nevada Test Site, Southern Nevada.'U.S. Geological Survey Open-File Report 97-678, scale 1:48,000, Denver, CO.

Colton, R. B. and E. J. McKay. 1966. Geologic Map of the Yucca Flat Quadrangle, Nye and Lincoln Counties, Nevada. U.S. Geological Survey Geologic Quadrangle Map GQ-582, scale 1:24,000.

DOE/NV, see U.S. Department of Energy, Nevada Operations Office.

Federal Facilities Agreement Consent Order. 1996. Agreed to by the U.S. Department of Energy, the Department of Defense, and the State of Nevada. Las Vegas, NV.

FFACO. See Federal Facilities Agreement Consent Order. 
Gonzales, J. L., and S. L. Drellack. 1999. Written communication. Subject: "Addendum to the Descriptive Narrative for the Hydrogeologic Model of the Yucca Flat Corrective Action Unit: Northern Extension.”' Bechtel Nevada, Las Vegas, NV.

Gonzales, J. L., S. L. Drellack, and M. J. Townsend. 1998. Written communication. Subject: "Descriptive Narrative for the Hydrogeologic Model at the Yucca Flat Corrective Action Unit." Bechtel Nevada, Las Vegas, NV.

Hale, G. S., D. A. Trudeau, and C. S. Savard. 1995. Water-Level Data from Wells and Test Holes Through 1991, and Potentiometric Contours as of 1991 for Yucca Flat, Nevada Test Site, Nye County, Nevada. Water-Resources Investigations Report 95-4177. U.S. Geological Survey, Denver, CO.

Hawkins, W. L., A. P. Cavazos, and P. H. Thompson. 1987. "Geologic and Hydrologic Investigations at the ALEMAN (U-3kz) Site, and Other Sites in Yucca Flat, the Nevada Test Site." In: Proceedings of the Fourth Symposium on Containment of Underground Nuclear Explosions, Lawrence Livermore National Laboratory CONF-870961, v. 2, p. 387-398.

Howard, N. 1977. Written communication. Subject: "U2en Preliminary Site Characteristics Summary." Lawrence Livermore National Laboratory Memorandum AGTG 77-90. Livermore, CA.

IT, see IT Corporation.

IT Corporation. 1996. Potentiometric Data Task Documentation Package (Phase I, Data Analysis Documentation, Volume II), ITLV/10972-181. Las Vegas, NV.

IT Corporation. 2002. Yucca Flat Hydrogeologic Investigation Wells Drilling and Completion Criteria, ITLV/13052-164. Las Vegas, NV.

Laczniak, R. J., J. C. Cole, D. A. Sawyer, and D. A. Trudeau. 1996. Summary of Hydrogeologic Controls on the Movement of Groundwater at the Nevada Test Site, Nye County, Nevada. Water-Resources Investigations Report 96-4-109. U.S. Geological Survey, Carson City, NV.

McKague, H. L. 1973. Written communication. Subject: "Site Characteristics Summary - U2bs." Lawrence Livermore Laboratory Memorandum UOPKB 73-28. Livermore, CA.

Pawloski, G. A. 1985. Written communication. Subject: "U2gb Preliminary Site Characteristics Summary.” Lawrence Livermore Laboratory Memorandum CP 85-83. Livermore, CA.

Shaw, see Shaw Environmental, Inc.

Shaw Environmental, Inc. 2003. Written communication prepared for NNSA/NSO. Subject: "Yucca Flat ER-2-1 Well Data Report," August, 2003. Las Vegas, NV. 
Slate, J. L., M. E. Berry, P. D., Rowley, C. J. Fridrich, K. S. Morgan, J. B. Workman, O. D. Young, G. L. Dixon, V. S. Williams, E. H. McKee, D. A. Ponce, T. G. Hildenbrand, WC Swadley, S.

C. Lundstrom, E. B. Ekren, R. G. Warren, J. C. Cole, R. J. Fleck, M. A. Lanphere, D. A. Sawyer, S. A. Minor, D. J. Grunwald, R. J. Laczniak, C. M. Menges, J. C. Yount, and A. S. Jayko. 1999. Digital Geologic Map of the Nevada Test Site and Vicinity, Nye, Lincoln, and Clark Counties, Nevada, and Inyo County, California. U.S. Geological Survey Open-File Report 99-554-A.

Tewhey, J. 1975. Written communication. Subject: “Site Characteristics Summary - U2ek.” Lawrence Livermore Laboratory Report UOPKB 75-111. Livermore, CA.

U.S. Department of Energy, Nevada Operations Office. 1997. Regional Groundwater Flow and Tritium Transport Modeling and Risk Assessment of the Underground Test Area, Nevada Test Site, Nevada, DOE/NV-477. Las Vegas, NV: IT Corporation.

U.S. Department of Energy, Nevada Operations Office. 2000a. Corrective Action Investigation Plan for Corrective Action Unit 97: Yucca Flat/Climax Mine, Nevada Test Site, Nevada. DOE/NV--659. Las Vegas, NV.

U.S. Department of Energy, Nevada Operations Office. 2000b. United States Nuclear Tests, July 1945 through September 1992. DOE/NV-209, Revision 15. Las Vegas, NV.

U.S. Department of Energy, Nevada Operations Office. 2002a. Attachment 1, "Fluid Management Plan for the Underground Test Area Project. Rev. 3,” DOE/NV--370. Las Vegas, NV.

U.S. Department of Energy, Nevada Operations Office. 2002b. Underground Test Area (UGTA) Waste Management Plan. DOE/NV--343, Rev. 2. Las Vegas, NV.

Warren, R. G., D. A. Sawyer, F. M. Byers, Jr., and G. L. Cole. 2000. A Petrographic/ Geochemical Database and Stratigraphic and Structural Framework for the Southwestern Nevada Volcanic Field. Los Alamos National Laboratory Report LA-UR-00-3791.

WoldeGabriel, G., S. Chipera, G. Keating, E. Kluk, S. Levy, and P. Snow. 2003. Written communication. Subject: "Preliminary Geological Characterization of Well ER-2-1, Yucca Flat, Nevada Test Site.” Los Alamos National Laboratory. Las Alamos, NM.

Winograd, I. J. and W. Thordarson. 1975. Hydrogeologic and Hydrochemical Framework, South-Central Great Basin, Nevada-California, with Special Reference to the Nevada Test Site. U.S. Geological Survey Professional Paper 712-C.

Wohletz, K., and W. L. Hawkins. 1998. "Effects of Underground Nuclear Testing Below the Water Table on Groundwater and Radionuclide Migration in Areas 1, 3, 4, and 7 (Tuff Pile 1), Yucca Flat, Nevada Test Site.” EES-1 UGTA FY98 Report, Los Alamos National Laboratory. Las Alamos, NM. 
Wycoff, R. C., National Nuclear Security Administration Nevada Site Office. 2003. Letter to

P. J. Liebendorfer (Nevada Division of Environmental Protection) titled, "Well-Site Fluid Management Strategy, DOE NNSA/NV, Yucca Flat Drilling Program, Nevada Test Site, Well ER2-1 Corrective Action Unit \#97, Yucca Flat/Climax Mine," February 18, 2003. Las Vegas, NV. 


\section{Appendix A \\ Drilling Data}

A-1 Drilling Parameter Logs for Well ER-2-1

A-2 Casing Data for Well ER-2-1

A-3 Well ER-2-1 Drilling Fluids and Cement Composition 
Appendix A-1

Drilling Parameter Logs for Well ER-2-1 


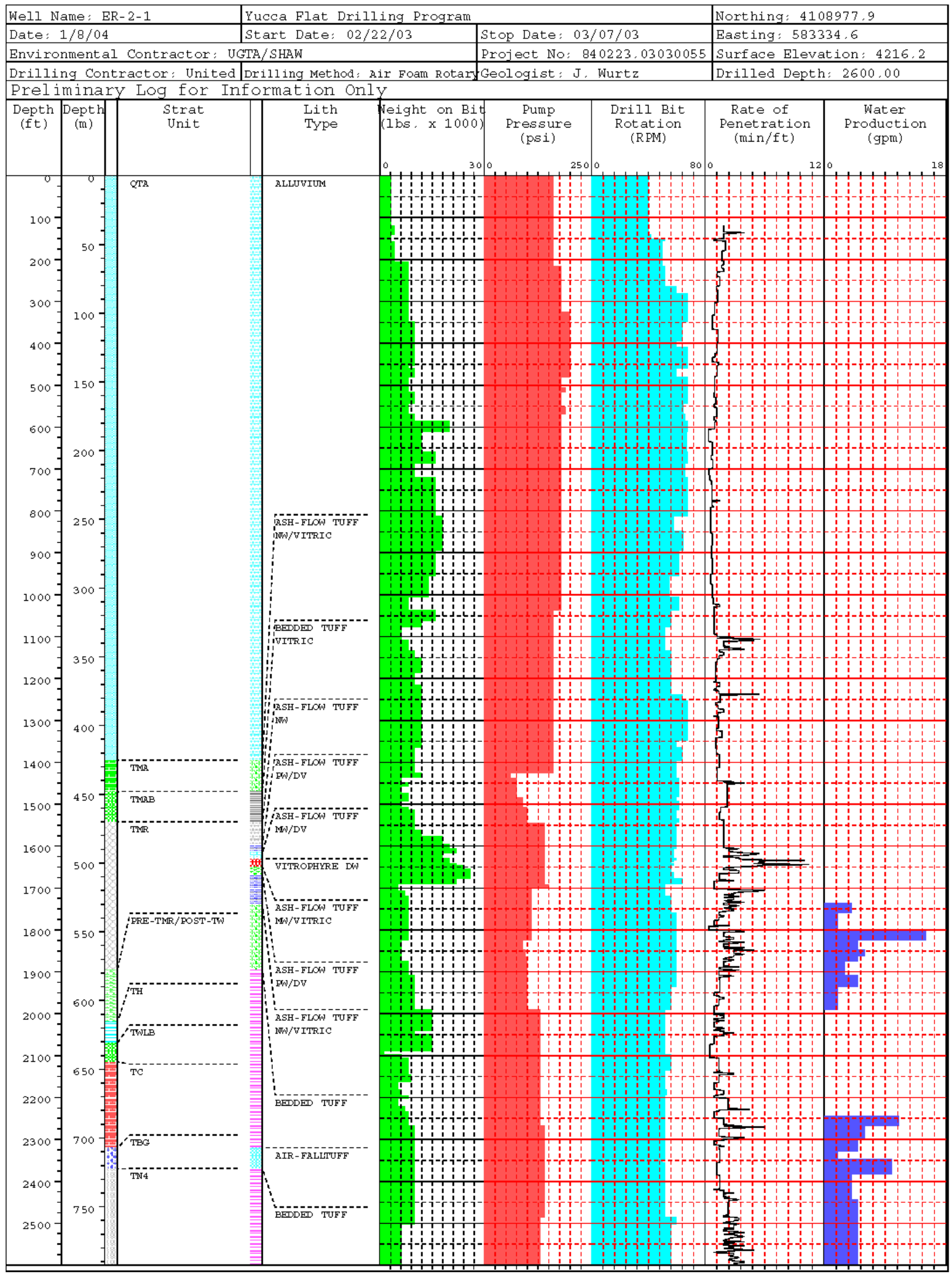


This page intentionally left blank.

A-1-2 
Appendix A-2

Casing Data for Well ER-2-1 
Table A-2

Casing Data for Well ER-2-1

\begin{tabular}{|c|c|c|c|c|c|c|c|}
\hline Casing & $\begin{array}{c}\text { Depth Interval } \\
\text { meters } \\
\text { (feet) }\end{array}$ & Type & Grade & $\begin{array}{l}\text { Outside } \\
\text { Diameter } \\
\text { centimeters } \\
\text { (inches) }\end{array}$ & $\begin{array}{c}\text { Inside } \\
\text { Diameter } \\
\text { centimeters } \\
\text { (inches) }\end{array}$ & $\begin{array}{c}\text { Wall } \\
\text { Thickness } \\
\text { centimeters } \\
\text { (inches) }\end{array}$ & $\begin{array}{l}\text { Weight } \\
\text { per foot } \\
\text { (pounds) }\end{array}$ \\
\hline Conductor & $\begin{array}{c}0 \text { to } 35.9 \\
(0 \text { to } 117.7)\end{array}$ & $\begin{array}{c}\text { Carbon Steel } \\
\text { PE Weld }\end{array}$ & K55 & $\begin{array}{l}50.8 \\
(20)\end{array}$ & $\begin{array}{c}48.57 \\
(19.124)\end{array}$ & $\begin{array}{l}1.27 \\
(0.5)\end{array}$ & 94.0 \\
\hline Surface & $\begin{array}{c}0 \text { to } 501.1 \\
(0 \text { to } 1,643.9)\end{array}$ & $\begin{array}{c}\text { Carbon } \\
\text { Steel }\end{array}$ & J55 & $\begin{array}{c}33.97 \\
(13.375)\end{array}$ & $\begin{array}{c}31.79 \\
(12.515)\end{array}$ & $\begin{array}{l}1.09 \\
(0.43)\end{array}$ & 54.5 \\
\hline Completion & $\begin{array}{c}0-633.7 \\
(0-2,079.2)\end{array}$ & $\begin{array}{l}\text { Carbon steel } \\
\text { with internal } \\
\text { epoxy } \\
\text { coating }\end{array}$ & N80 & $\begin{array}{c}19.37 \\
(7.625)\end{array}$ & $\begin{array}{l}17.701 \\
(6.969)\end{array}$ & $\begin{array}{c}0.833 \\
(0.328)\end{array}$ & 26.4 \\
\hline Piezometer & $\begin{array}{c}0 \text { to } 779.9 \\
(0 \text { to } 2,558.6)\end{array}$ & $\begin{array}{c}\text { Stainless } \\
\text { Steel }\end{array}$ & VP2EN & $\begin{array}{r}7.30 \\
(2.875) \\
\end{array}$ & $\begin{array}{r}5.92 \\
(2.33) \\
\end{array}$ & $\begin{array}{c}0.69 \\
(0.273) \\
\end{array}$ & 7.66 \\
\hline
\end{tabular}


This page intentionally left blank.

A-2-2 
Appendix A-3

Well ER-2-1 Drilling Fluids and Cement Composition 
Table A-3-1

Well ER-2-1 Drilling Fluids

\begin{tabular}{|c|c|}
\hline Typical Air-Foam Mix ${ }^{a}$ & Typical Air-Foam/Polymer Mix ${ }^{a}$ \\
\hline $\begin{array}{c}26.5 \text { to } 75.7 \text { liters ( } 7 \text { to } 20 \text { gallons) Geofoam }{ }^{\circledR b} \\
\text { and } 0.5 \text { liters of } \mathrm{LiBr} \\
\text { per } \\
7,949 \text { liters ( } 50 \text { barrels) water }\end{array}$ & 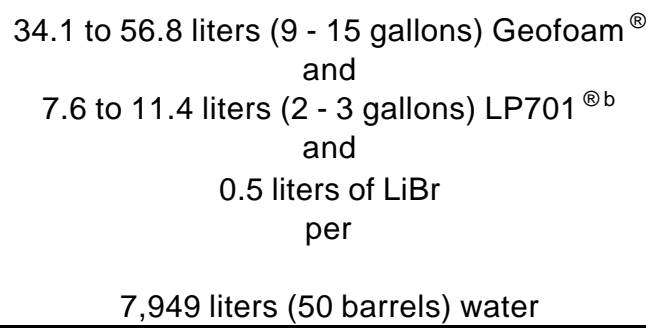 \\
\hline
\end{tabular}

a An air-foam ("soap") mix was used as the drilling fluid in Well ER-2-1. Various proportions of polymer were added to the air-foam to suit conditions during drilling below approximately 396.2 meters (1,300 feet).

b $\quad$ Geofoam ${ }^{\circledR}$ foaming agent and LP $701^{\circledR}$ polymer additive are products of Geo Drilling Fluids, Inc.

NOTES:

1. All water used to mix drilling fluids for Well ER-2-1 came from Water Well UE-16d in western Yucca Flat.

2. A concentrated solution of lithium bromide was added to all introduced fluids to make up a final concentration of 15 milligrams per liter.

Table A-3-2

Well ER-2-1 Cement Composition

\begin{tabular}{|c|c|c|c|c|}
\hline $\begin{array}{c}\text { Cement } \\
\text { Composition }\end{array}$ & $\begin{array}{l}\text { 20-in. } \\
\text { Conductor } \\
\text { Casing }\end{array}$ & $\begin{array}{l}\text { 13d -in. Surface } \\
\text { Casing }\end{array}$ & $\begin{array}{l}7 e^{-i n} . \\
\text { Completion } \\
\text { Casing }\end{array}$ & $\begin{array}{l}2 f \text {-in. } \\
\text { Piezometer } \\
\text { Tubing }\end{array}$ \\
\hline $\begin{array}{l}\text { Type II, first stage with } \\
\text { aggregate, remaining } \\
\text { stages with sand }\end{array}$ & $\begin{array}{l}0 \text { to } 36.3 \mathrm{~m}^{\mathrm{b}} \\
\left(0 \text { to } 119 \mathrm{ft}^{\mathrm{c}}\right)\end{array}$ & Not used & Not used & Not used \\
\hline Type II neat & Not used & $\begin{array}{c}\text { Annulus } \\
489.8 \text { to } 501.4 \mathrm{~m} \\
(1,607 \text { to } 1,645 \mathrm{ft})\end{array}$ & Not used & $\begin{array}{c}663.5 \text { to } 705.0 \mathrm{~m} \\
(2,177 \text { to } 2,313 \mathrm{ft}) \\
\text { Mixed with fill, } 681.2 \text { to } \\
700.1 \mathrm{~m}(2,235 \text { to } 2,297 \mathrm{ft})\end{array}$ \\
\hline
\end{tabular}
a inch
b meter(s)
c foot (feet)
d estimated 
This page intentionally left blank.

A-3-2 
Appendix B

Well ER-2-1 Fluid Management Data 


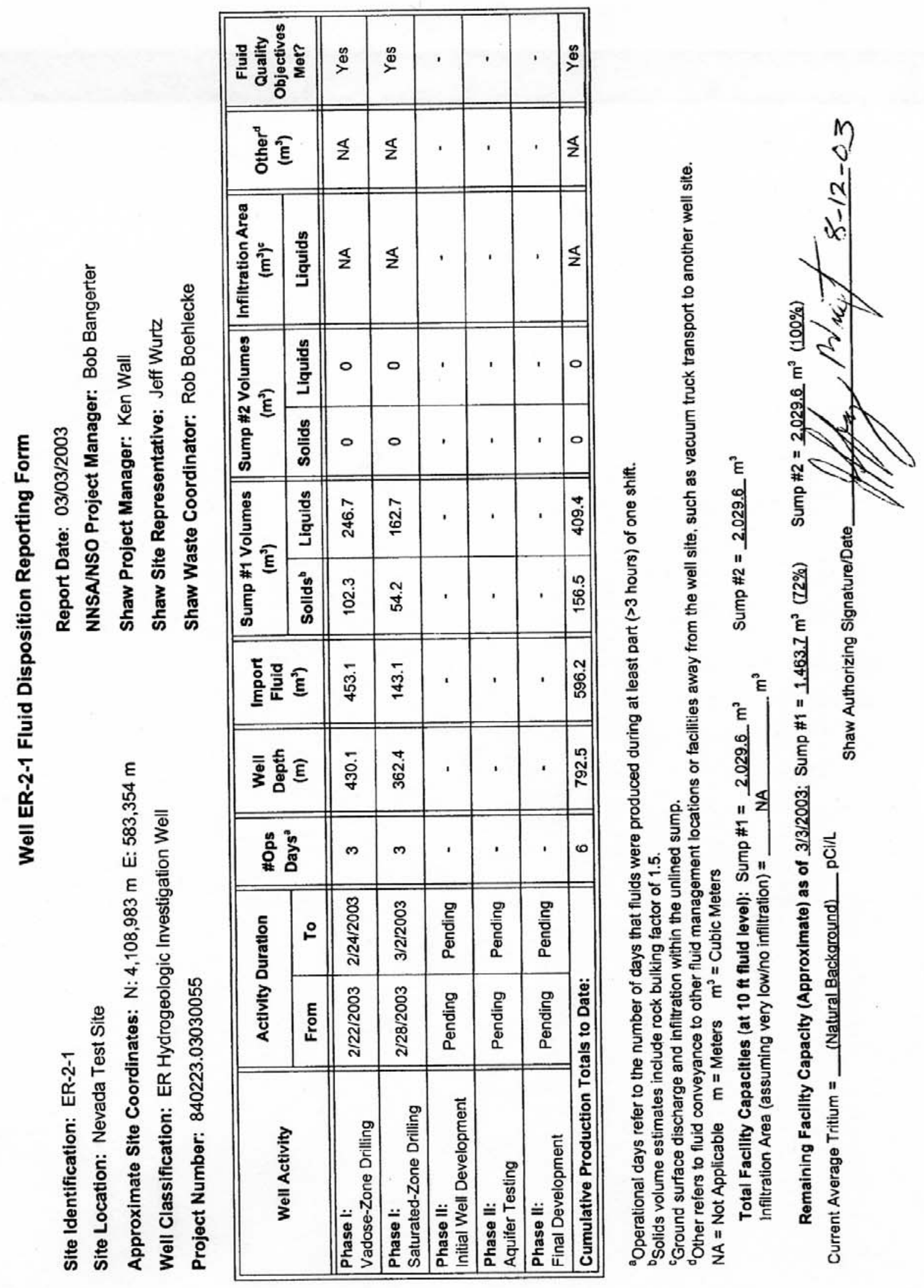


This page intentionally left blank.

B-2 
Appendix C

Detailed Lithologic Log for Well ER-2-1 


\section{Lithologic Log for Well ER-2-1}

\section{(Logged by S. L. Drellack and H. Gang, April 2003)}

Unless otherwise noted, the following descriptions refer to washed cuttings samples at $3.05 \mathrm{~m}$ (10 ft) intervals and percussion-gun sidewall samples acquired at various depths between 113.7 and 741.0 meters (373 and 2,431 feet). Colors are determined by comparing wet sample color to the Geological Society of America Rock-Color Chart. Stratigraphic contacts and lithologic divisions are tied to geophysical logs whenever possible.

\begin{tabular}{|c|c|c|c|c|c|}
\hline $\begin{array}{l}\text { Depth Interval } \\
\text { meters (feet) }\end{array}$ & $\begin{array}{l}\text { Thickness } \\
\text { meters } \\
\text { (feet) }\end{array}$ & $\begin{array}{l}\text { Sample } \\
\text { Type }^{\text {a }}\end{array}$ & $\begin{array}{l}\text { Laboratory } \\
\text { Analyses } \\
\text { (Sample } \\
\text { depth in feet) }\end{array}$ & Lithologic Description c & Stratigraphic Unit ${ }^{d}$ \\
\hline $\begin{array}{l}0-213.4 \\
(0-700)\end{array}$ & $\begin{array}{l}213.4 \\
(700)\end{array}$ & $\begin{array}{l}\text { DA, } \\
\text { DB1, } \\
\text { SWC }\end{array}$ & $\begin{array}{c}P, X R D \\
240\end{array}$ & $\begin{array}{l}\text { Alluvium: Grayish-orange-pink to dark-yellowish-brown; tuffaceous; } \\
\text { poorly indurated; poorly sorted, sand to pebble sizes; subangular to } \\
\text { subrounded; calcareous with caliche coating many fragments; slightly to } \\
\text { moderately calcareous; } 10 \text { to } 40 \text { percent Paleozoic rock fragments, } \\
\text { (mostly clastic fragments; carbonate fragments rare). Cuttings samples } \\
\text { are highly enriched in granule-sized harder fragments (no matrix material } \\
\text { present). }\end{array}$ & \multirow[t]{2}{*}{ Alluvium } \\
\hline $\begin{array}{l}213.4-425.2 \\
(700-1,395)\end{array}$ & $\begin{array}{l}211.8 \\
(695)\end{array}$ & $\begin{array}{l}\text { DA, } \\
\text { DB1, } \\
\text { SWC }\end{array}$ & $\begin{array}{l}P, X R D \\
1,180\end{array}$ & $\begin{array}{l}\text { Alluvium: Moderate yellowish-brown to grayish-orange-pink; tuffaceous; } \\
\text { calcareous; poorly to moderately sorted, mostly coarse sand size with } \\
\text { minor coarser material up to pebble size; subrounded to subangular. Less } \\
\text { than } 10 \text { percent Paleozoic rock fragments, decreasing with depth; } \\
\text { carbonate fragments rare. }\end{array}$ & \\
\hline $\begin{array}{c}425.2-448.1 \\
(1,395-1,470)\end{array}$ & $\begin{array}{l}22.9 \\
(75)\end{array}$ & $\begin{array}{l}\text { DB1, } \\
\text { SWC }\end{array}$ & $\begin{array}{c}\mathrm{P}, \mathrm{XRD}, \\
\mathrm{XRF}, \mathrm{Fe} \\
1,400 \quad 1,440\end{array}$ & $\begin{array}{l}\text { Ash-Flow Tuff: Moderate yellowish-brown; nonwelded; vitric; minor } \\
\text { pumice, grayish-orange at top of interval to dark yellowish-brown and very } \\
\text { pale orange to white below; common felsic phenocrysts (mostly feldspar } \\
\text { and quartz, minor chatoyant sanidine and scarce sphene); scarce biotite; } \\
\text { rare to minor lithic fragments; conspicuous dark yellowish-orange frothy } \\
\text { glass and glass shards. }\end{array}$ & $\begin{array}{l}\text { Ammonia Tanks } \\
\text { Tuff, Timber } \\
\text { Mountain Group }\end{array}$ \\
\hline $\begin{array}{c}448.1-455.7 \\
(1,470-1,495)\end{array}$ & $\begin{array}{c}7.6 \\
(25)\end{array}$ & $\begin{array}{l}\text { DB1, } \\
\text { SWC }\end{array}$ & $\begin{array}{l}P, X R D \\
1,480\end{array}$ & $\begin{array}{l}\text { Bedded Tuff: Moderate yellowish-brown; vitric; poorly indurated; } \\
\text { common white and yellowish-gray pumice; common felsic phenocrysts } \\
\text { (quartz and feldspar); scarce mafic minerals (biotite with lesser } \\
\text { hornblende); scarce lithic fragments; weakly calcareous in upper part. } \\
\text { Reworked tuff at } 454.5 \mathrm{~m}(1,491 \mathrm{ft}) \text { is silicic. }\end{array}$ & $\begin{array}{c}\text { Bedded Ammonia } \\
\text { Tanks Tuff, Timber } \\
\text { Mountain Group }\end{array}$ \\
\hline
\end{tabular}




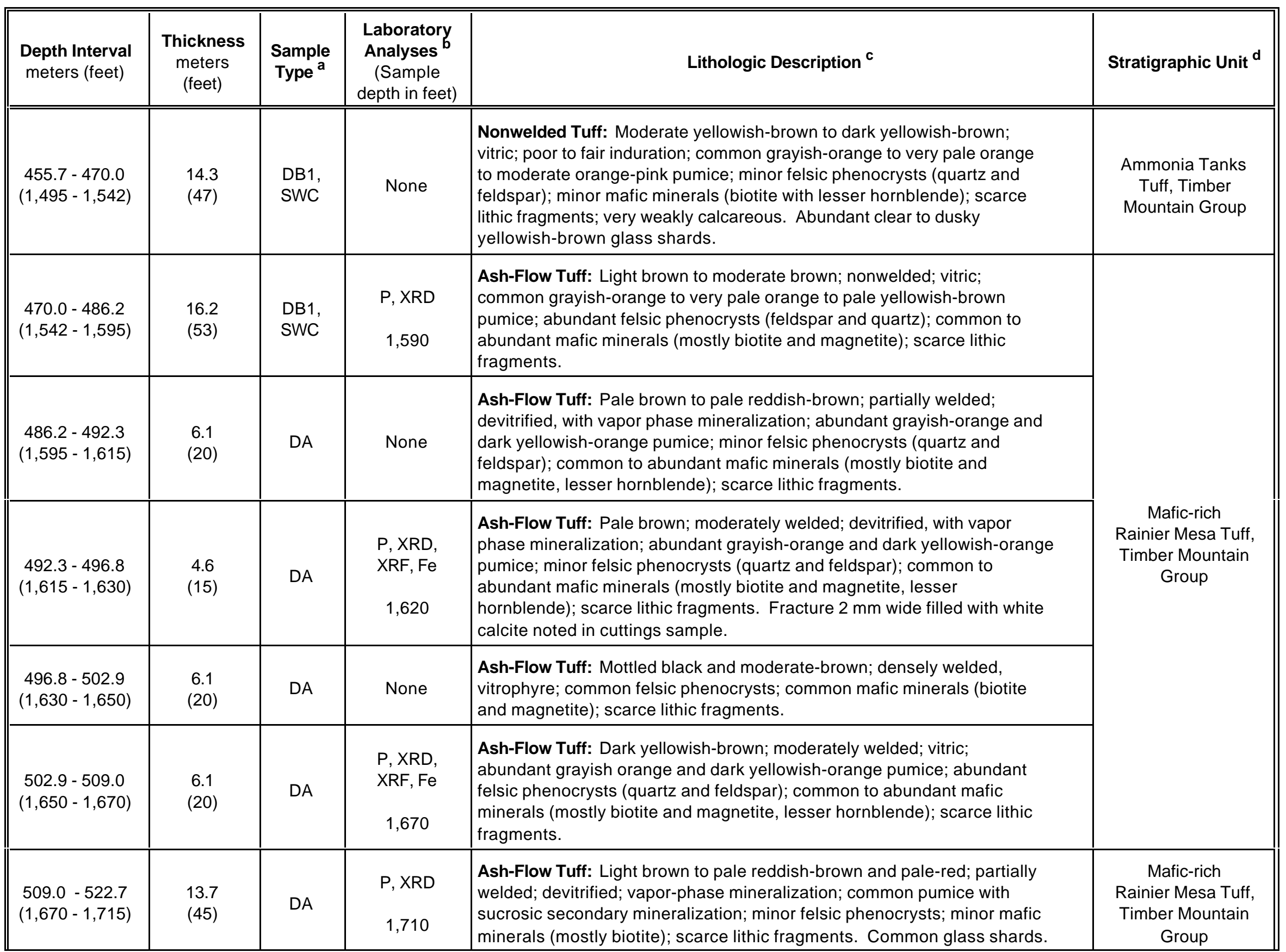




\begin{tabular}{|c|c|c|c|c|c|}
\hline $\begin{array}{l}\text { Depth Interval } \\
\text { meters (feet) }\end{array}$ & $\begin{array}{l}\text { Thickness } \\
\text { meters } \\
\text { (feet) }\end{array}$ & $\begin{array}{l}\text { Sample } \\
\text { Type }^{\text {a }}\end{array}$ & $\begin{array}{l}\text { Laboratory } \\
\text { Analyses } \\
\text { (Sample } \\
\text { depth in feet) }\end{array}$ & Lithologic Description ${ }^{c}$ & Stratigraphic Unit ${ }^{d}$ \\
\hline $\begin{array}{c}522.7-530.4 \\
(1,715-1,740)\end{array}$ & $\begin{array}{l}7.6 \\
(25)\end{array}$ & $\begin{array}{l}\text { DA, } \\
\text { SWC }\end{array}$ & None & $\begin{array}{l}\text { Ash-Flow Tuff: Light brown; partially welded; devitrified; common } \\
\text { pumice with sucrosic secondary mineralization; minor felsic phenocrysts; } \\
\text { scarce mafic minerals (mostly biotite); scarce lithic fragments. }\end{array}$ & \multirow{3}{*}{$\begin{array}{l}\text { Mafic-poor } \\
\text { Rainier Mesa Tuff, } \\
\text { Timber Mountain } \\
\text { Group }\end{array}$} \\
\hline $\begin{array}{c}530.4-551.7 \\
(1,740-1,810)\end{array}$ & $\begin{array}{l}21.3 \\
(70)\end{array}$ & $\begin{array}{l}\text { DA, } \\
\text { SWC }\end{array}$ & $\begin{array}{l}P, X R D \\
1,780\end{array}$ & $\begin{array}{l}\text { Ash-Flow Tuff: Light brown to moderate reddish-orange and pale } \\
\text { reddish-brown; nonwelded; vitric; common grayish-orange-pink pumice; } \\
\text { common felsic phenocrysts; scarce mafic minerals; scarce lithic } \\
\text { fragments; common clear and dusky yellowish-brown glass shards. } \\
\text { Appears 'waxy' at } 541.3 \mathrm{~m}(1,776 \mathrm{ft}) \text {. }\end{array}$ & \\
\hline $\begin{array}{l}551.7-577.6 \mathrm{~m} \\
(1,810-1,895)\end{array}$ & $\begin{array}{l}25.9 \\
(85)\end{array}$ & $\begin{array}{l}\text { DB1, } \\
\text { SWC }\end{array}$ & $\begin{array}{l}\text { P, XRD, } \\
\text { XRF, Fe } \\
1,890\end{array}$ & $\begin{array}{l}\text { Ash-Flow Tuff: Light brown to moderate orange-pink; vitric; nonwelded, } \\
\text { friable; minor light gray to grayish-orange-pink pumice with sucrosic } \\
\text { secondary mineralization; appears eroded; felsic phenocrysts are mostly } \\
\text { quartz (some dipyramidal) and feldspar; scarce mafic minerals; scarce } \\
\text { lithic fragments. Common clear glass shards in parts. }\end{array}$ & \\
\hline $\begin{array}{c}577.6-615.7 \\
(1,895-2,020)\end{array}$ & $\begin{array}{l}38.1 \\
(125)\end{array}$ & $\begin{array}{l}\text { DA, } \\
\text { SWC }\end{array}$ & $\begin{array}{l}\mathrm{P}, \mathrm{XRD} \\
\mathrm{XRF}, \mathrm{Fe}, \mathrm{MP} \\
\quad 1,950\end{array}$ & $\begin{array}{l}\text { Bedded Tuff: Very-pale-orange to pale yellowish-brown, becoming } \\
\text { yellowish-gray to grayish-yellow below } 609.6 \mathrm{~m}(2,000 \mathrm{ft}) \text {; vitric to } \\
\text { devitrified, becoming zeolitic below } 583.7 \mathrm{~m}(1,915 \mathrm{ft}) \text {, poorly indurated; } \\
\text { minor pumice; minor to common felsic crystals; scarce (though variable) } \\
\text { mafic minerals; rare to minor small lithic fragments. }\end{array}$ & $\begin{array}{l}\text { Pre-Rainier Mesa, } \\
\text { post-Wahmonie } \\
\text { bedded tuff, } \\
\text { undifferentiated }\end{array}$ \\
\hline $\begin{array}{c}615.7-630.9 \\
(2,020-2,070)\end{array}$ & $\begin{array}{l}15.2 \\
(50)\end{array}$ & $\begin{array}{l}\text { DA, } \\
\text { SWC }\end{array}$ & $\begin{array}{l}\mathrm{P}, \mathrm{XRD} \\
\mathrm{XRF}, \mathrm{Fe}, \mathrm{MP} \\
\quad 2,040\end{array}$ & $\begin{array}{l}\text { Bedded Tuff: Yellowish-gray; zeolitic; moderately indurated; minor } \\
\text { yellowish-gray to grayish-yellow pumice; scarce felsic crystals; scarce } \\
\text { mafic minerals; scarce to rare lithic fragments. }\end{array}$ & $\begin{array}{l}\text { Calico Hills } \\
\text { Formation }\end{array}$ \\
\hline $\begin{array}{c}630.9-644.7 \\
(2,070-2,115)\end{array}$ & $\begin{array}{l}13.7 \\
(45)\end{array}$ & $\begin{array}{l}\text { DA, } \\
\text { SWC }\end{array}$ & $\begin{array}{l}\mathrm{P}, \mathrm{XRD} \\
\mathrm{XRF}, \mathrm{Fe}, \mathrm{MP} \\
\quad 2,100\end{array}$ & $\begin{array}{l}\text { Bedded Tuff: Yellowish-gray; zeolitized; moderately indurated; minor } \\
\text { white and grayish-yellow pumice; common felsic crystals (mostly } \\
\text { feldspar); abundant mafic minerals (biotite, magnetite and hornblende); } \\
\text { rare lithic fragments. Some dark yellowish-brown reworked tuff: minor } \\
\text { very pale orange pumice; abundant small mafic minerals; minor lithic } \\
\text { fragments. Lesser pumice-rich air-fall tuff: pale greenish-yellow and } \\
\text { grayish-yellow pumice; abundant mafic minerals (as above) with dark } \\
\text { yellowish-orange stains associated with magnetite grains. }\end{array}$ & $\begin{array}{l}\text { Wahmonie } \\
\text { Formation, } \\
\text { Tuff of } \\
\text { Wahmonie Flat }\end{array}$ \\
\hline
\end{tabular}




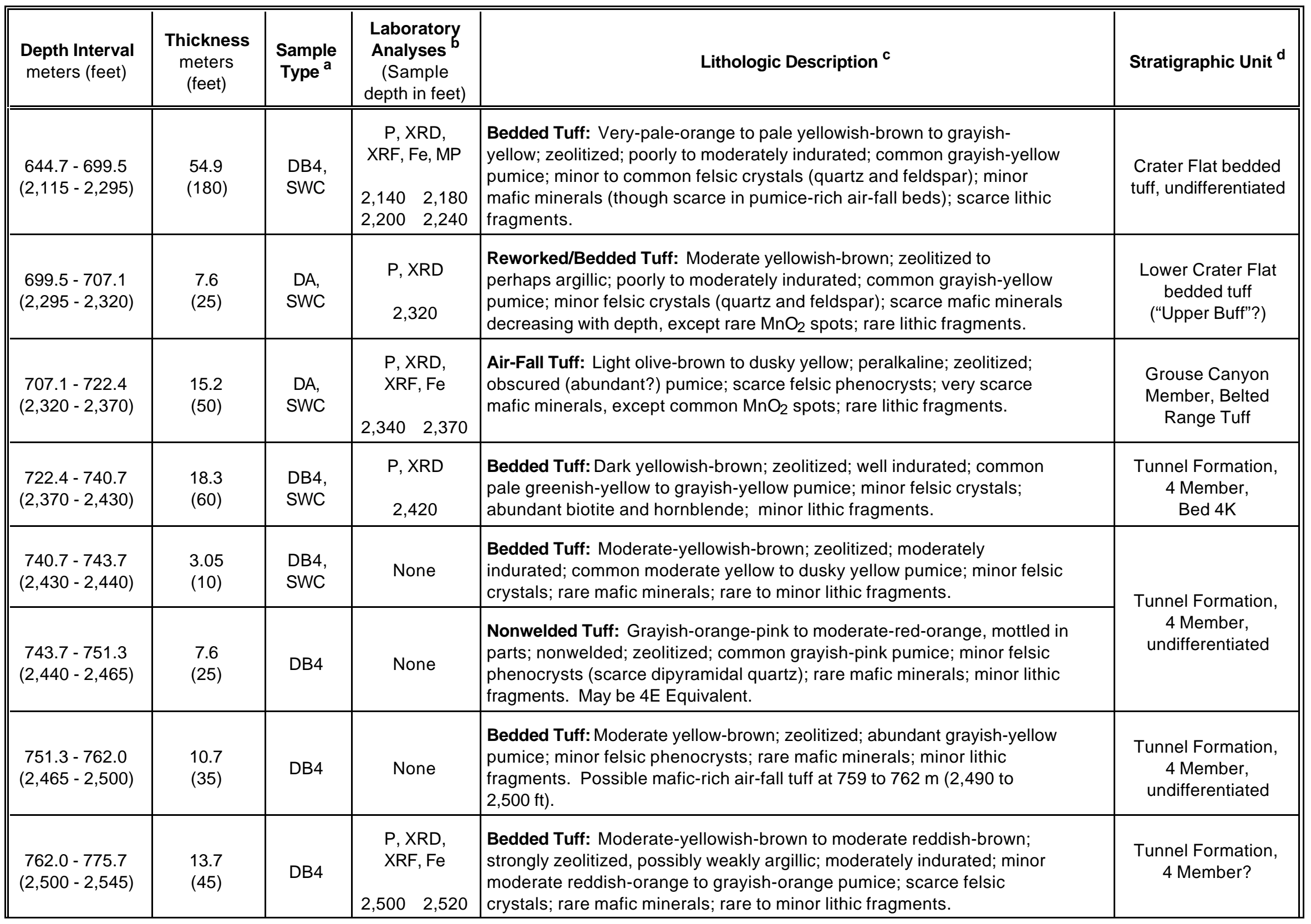




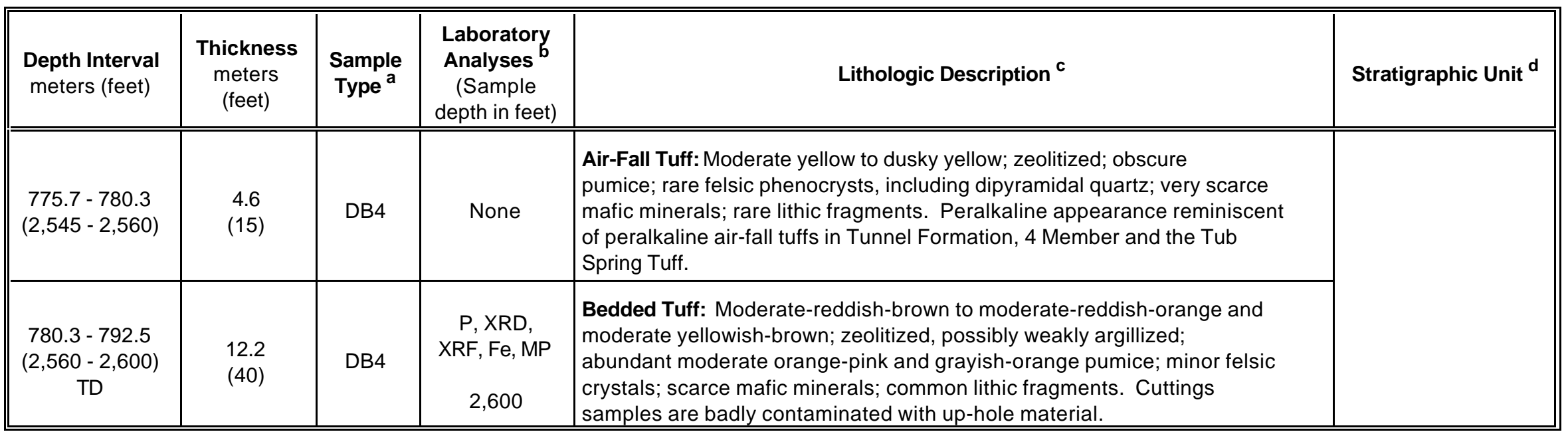

a $\quad$ DA = drill cuttings that represent lithologic character of interval; DB1 $=$ drill cuttings enriched in hard components; $\mathbf{D B} 4=$ cuttings that are intimate mixtures of units, generally less than $50 \%$ of drill cuttings represent lithologic character of interval; $\mathbf{S W C}=$ Sidewall core.

b $\quad \mathbf{P}=$ petrographic microscope $; \mathbf{T S}=$ polished thin section $\mathbf{X R D}=\mathrm{x}$-ray diffraction; $\mathbf{X R F}=\mathrm{x}$-ray fluorescence $; \mathbf{F e}=\mathrm{Fe}^{2+} / \mathrm{Fe}^{3+} ; \mathbf{M P}=\mathrm{electron}$ microprobe. See Table 3-2 of this report for additional information.

c Descriptions are based mainly on visual examination of lithologic samples using a 10x- to 40x-zoom binocular microscope, and incorporating observations from geophysical logs and results of laboratory analyses. Colors describe wet sample color.

Abundances for felsic phenocrysts, pumice fragments, and lithic fragments: trace = only one or two individuals observed; rare $=\leq 1 \%$; minor $=5 \%$; common $=10 \%$; abundant $=15 \%$; very abundant $\geq 20 \%$.

Abundances for mafic minerals: trace $=$ only one or two individuals observed; rare $=\leq 0.05 \%$; minor $=0.2 \%$; common $=0.5 \%$; abundant $=1 \%$; very abundant $=\geq 2 \%$.

d Stratigraphic assignments for the Tertiary-age tuffs are based on geochemical and mineralogical analyses by WoldeGabriel (2003). 
This page intentionally left blank.

C-6 
Appendix D

Geophysical Logs Run in Well ER-2-1 
Appendix D contains unprocessed data presentations of selected geophysical logs run in Well ER-2-1. Table D-1 summarizes the logs presented. See Table 3-3 for more information.

\section{Table D-1}

\section{Well ER-2-1 Geophysical Logs Presented}

\begin{tabular}{|c|c|c|c|c|}
\hline Log Type & $\begin{array}{l}\text { Run } \\
\text { Number }\end{array}$ & Date & meters $^{\text {Log }}$ & val feet \\
\hline Caliper & $\begin{array}{l}\text { CA6-1 } \\
\text { CA6-2 }\end{array}$ & $\begin{array}{l}2 / 25 / 2003 \\
3 / 04 / 2003\end{array}$ & $\begin{array}{r}25.0-508.4 \\
426.7-766.0\end{array}$ & $\begin{array}{c}82-1,668 \\
1,400-2,513\end{array}$ \\
\hline Epithermal Neutron & $\begin{array}{l}\text { DSEN-1 } \\
\text { DSEN-2 }\end{array}$ & $\begin{array}{l}2 / 25 / 2003 \\
3 / 03 / 2003\end{array}$ & $\begin{array}{c}18.3-510.5 \\
487.7-761.4\end{array}$ & $\begin{array}{c}60-1,675 \\
1,600-2,498\end{array}$ \\
\hline Density & $\begin{array}{l}\text { SDL-1 } \\
\text { SDL-2 }\end{array}$ & $\begin{array}{l}2 / 25 / 2003 \\
3 / 03 / 2003\end{array}$ & $\begin{array}{r}18.3-510.5 \\
487.7-761.4\end{array}$ & $\begin{array}{c}60-1,675 \\
1,600-2,498\end{array}$ \\
\hline Induction (resistivity) & $\mathrm{HRI}-1$ & $02 / 25 / 2003$ & $36.0-509.0$ & $118-1,670$ \\
\hline Dual Laterolog & DLL-1 & 3/03/2003 & $635.5-764.4$ & $2,085-2,508$ \\
\hline Gamma Ray & $\begin{array}{l}\text { GR-3 } \\
\text { GR-8 }\end{array}$ & $\begin{array}{l}2 / 25 / 2003 \\
3 / 03 / 2003\end{array}$ & $\begin{array}{r}25.0-509.0 \\
501.1-768.7\end{array}$ & $\begin{array}{r}82.0-1,670 \\
1,644-2,522\end{array}$ \\
\hline $\begin{array}{c}\text { Spectral Gamma Ray } \\
\text { (potassium, thorium, uranium) }\end{array}$ & $\begin{array}{l}\text { SGR-1 } \\
\text { SGR-2 }\end{array}$ & $\begin{array}{l}2 / 25 / 2003 \\
3 / 03 / 2003\end{array}$ & $\begin{array}{r}12.8-499.6 \\
487.7-756.2 \\
\end{array}$ & $\begin{array}{c}42-1,639 \\
1,600-2,481\end{array}$ \\
\hline Temperature & TL-3 & $3 / 042003$ & $535.2-716.9$ & $1,756-2,352$ \\
\hline
\end{tabular}




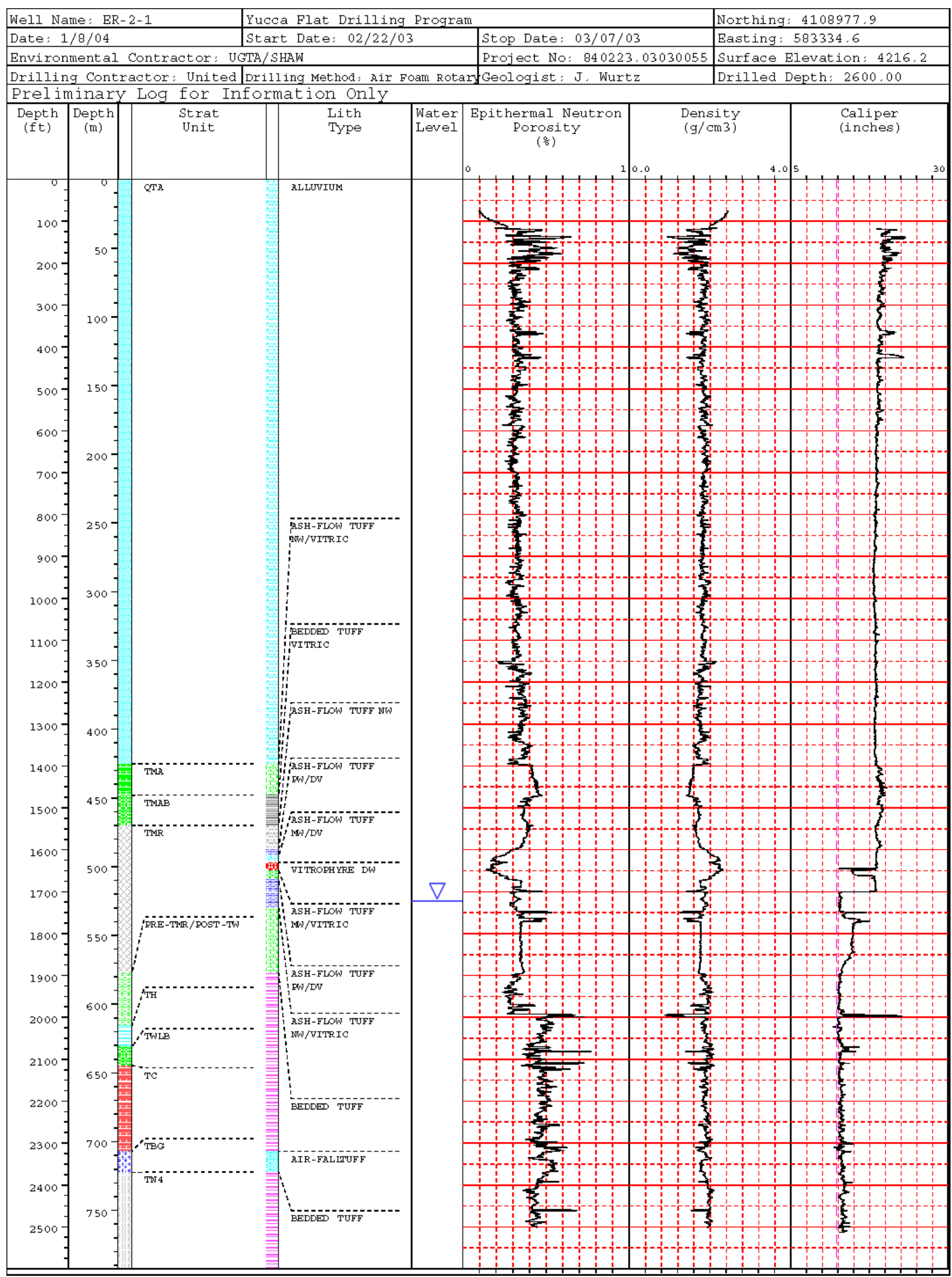

D-2 


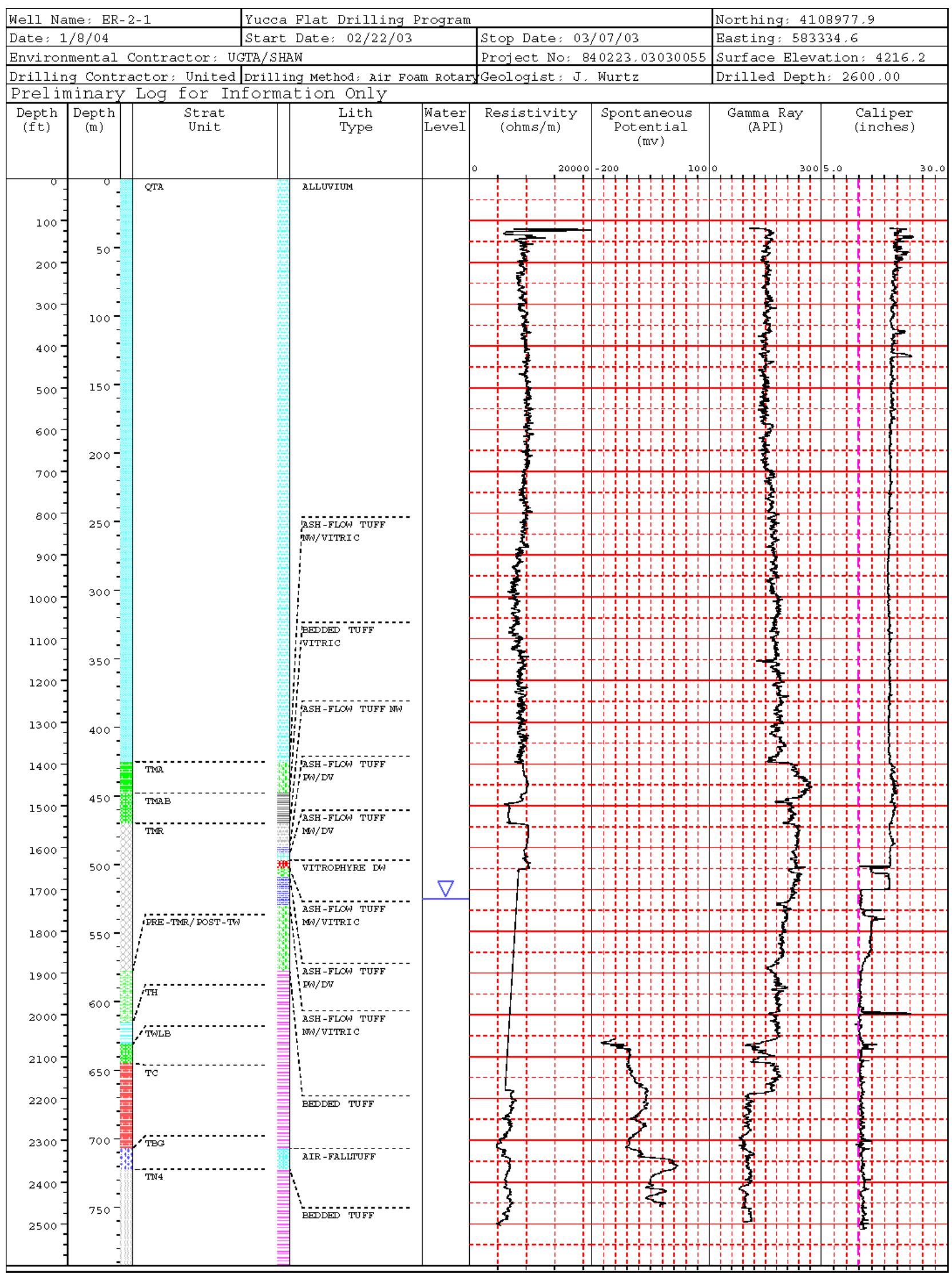




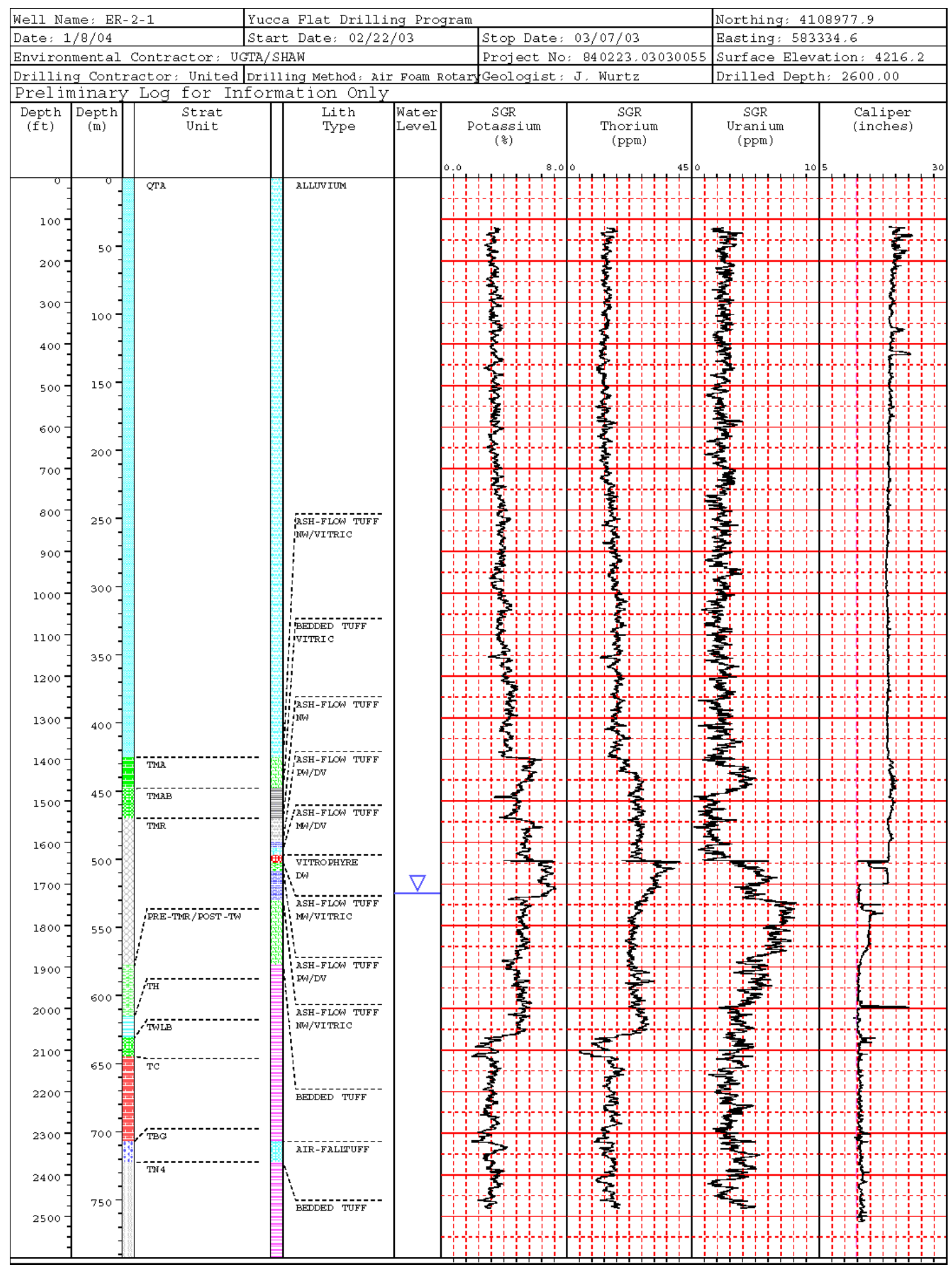




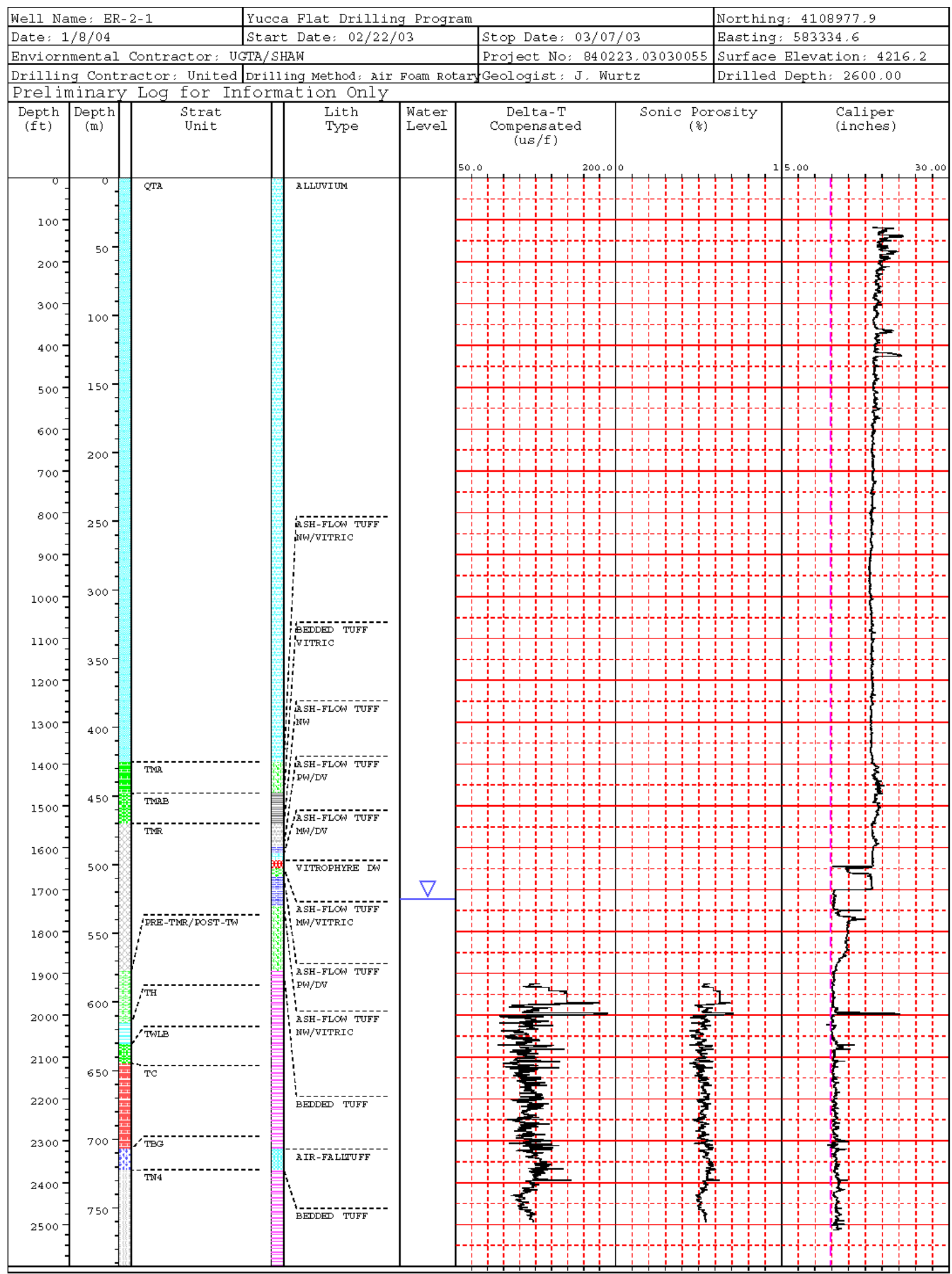




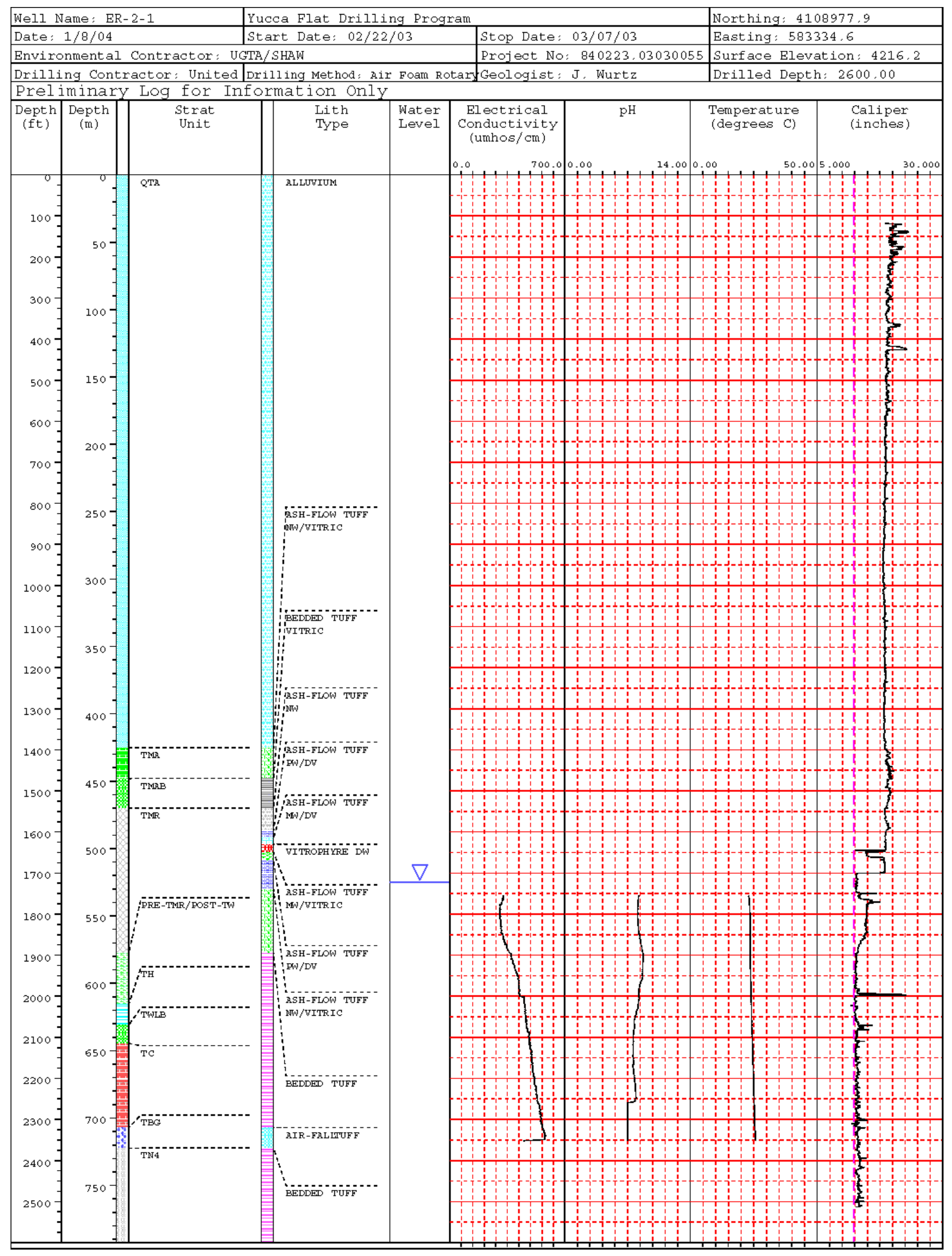




\section{Distribution List}

$\underline{\text { Copies }}$

R. M. Bangerter

U.S. Department of Energy

National Nuclear Security Administration

Nevada Site Office

Environmental Restoration Division

P.O. Box 98518, M/S 505

Las Vegas, NV 89193-8518

U.S. Department of Energy

National Nuclear Security Administration

Nevada Site Office

Technical Library

P.O. Box 98518, M/S 505

Las Vegas, NV 89193-8518

U.S. Department of Energy

National Nuclear Security Administration

Nevada Site Office

Public Reading Facility

c/o Nuclear Testing Archive

P.O. Box 98518, M/S 505

Las Vegas, NV 89193-8518

U.S. Department of Energy

1 (electronic)

Office of Scientific and Technical Information

Post Office Box 62

175 Oak Ridge Turnpike

Oak Ridge, Tennessee 37831-0062

K. A. Hoar, Director

U.S. Department of Energy

National Nuclear Security Administration

Nevada Site Office

Environment, Safety and Health Division

P.O. Box 98518, M/S 505

Las Vegas, NV 89193-8518

P. K. Ortego

Bechtel Nevada

P.O. Box 98521, MS NLV082

Las Vegas, NV 89193-8521 
Distribution List (continued)

$\underline{\text { Copies }}$

John McCord

1

UGTA Project Manager

Stoller-Navarro Joint Venture

7710 West Cheyenne Ave.

Building 3

Las Vegas, NV 89129

Stoller-Navarro Library

Stoller-Navarro Joint Venture

7710 West Cheyenne Ave.

Building 3

Las Vegas, NV 89129

W. L. Hawkins

Los Alamos National Laboratory

P. O. Box 1663

Los Alamos, NM 87545-1663

G. A. Pawloski

Lawrence Livermore National Laboratory

P. O. Box 808

Livermore, CA 94551-0808

T. P. Rose

Lawrence Livermore National Laboratory

P. O. Box 808

Livermore, CA 94551-0808

B. K. Thompson

DOE/USGS Cooperative Program Manager

U.S. Geological Survey

Water Resources Division

6770 South Paradise Road

Las Vegas, NV 89119-3721

C. E. Russell

Desert Research Institute

755 East Flamingo Road

P.O. Box 19040

Las Vegas, NV 89119-7363 